
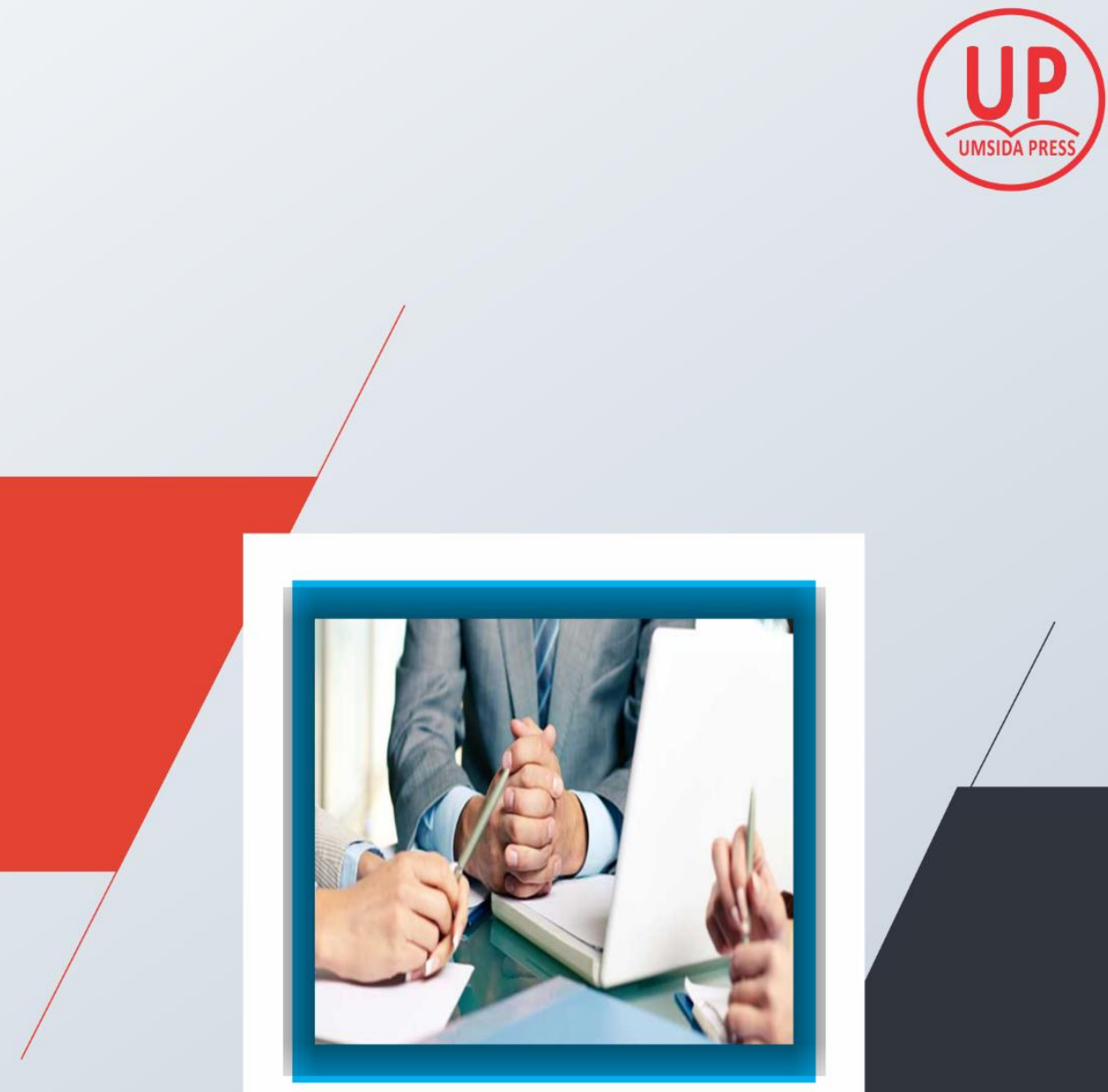

BUKU AJAR

PERILAKU ORGANISASI

SUMARTIK, SE, MM 


\section{PERILAKU ORGANISASI}

\section{PENULIS :}

SUMARTIK, SE. MM

\section{Diterbitkan oleh}

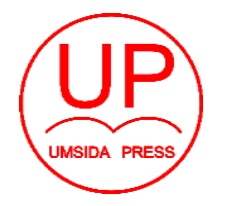

UMSIDA PRESS

JI. Mojopahit 666 B Sidoarjo 
BUKU AJAR

\section{PERILAKU ORGANISASI}

\section{Penulis :}

SUMARTIK, SE. MM

\section{ISBN :}

978-602-5914-62-1

\section{Editor :}

Septi Budi Sartika, M.Pd

M. Tanzil Multazam, S.H., M.Kn.

\section{Copy Editor :}

Fika Megawati, S.Pd., M.Pd.

Design Sampul dan Tata Letak :

Mochamad Nashrullah, S.Pd

\section{Penerbit :}

UMSIDA Press

\section{Redaksi :}

Universitas Muhammadiyah Sidoarjo

J1. Mojopahit No 666B

Sidoarjo, Jawa TImur

Cetakan pertama, Agustus 2018

C Hak cipta dilindungi undang-undang

Dilarang memperbanyak karya tulis ini dengan suatu apapun tanpa ijin tertulis dari penerbit. 


\section{KATA PENGANTAR}

Alhamdulillah, puji syukur penulis panjatkan kehadirat Alloh SWT, yang telah melimpahkan rahmat dan ridho-Nya sehingga buku "Perilaku Organisasi" dapat penulis selesaikan.

Buku Perilaku Organisasi ini seluruhnya terdiri dari 10 bab yang terbagi dalam 4 bagian; Bagian I ditujukan untuk memberikan pemahaman tentang pengertian, ruang lingkup budaya organisasi dan prilaku individu. Bagian II menguraikan tentang persepsi, atribut dan emosi serta motivasi. Bagian III menguraikan tentang evaluasi, umpan balik dan penghargaan terhadap karyawan. Bagian IV menguraikan tentang kelompok dan tim serta bagaimana mengelola konflik dalam suatu organisasi.

Penulis berharap dengan memaparkan berbagai aspek yang berhubungan dengan kegiatan perilaku organisasi dalam 10 bab, buku ini sudah dapat memberikan ilmu kepada para mahasiswa yang mempelajari mata kuliah Perilaku Organisasi untuk dapat memahami aktivitas di dalam perusahaan.

Akhirnya saya berharap semoga buku ini dapat memberikan manfaat kepada sesama manusia dan besar harapan penulis agar pembaca dapat menjadikan buku perilaku organisasi ini sebagai referensi dalam proses pembelajaran. 


\section{DAFTAR ISI}

\section{KATA PENGANTAR}

\section{BAB 1}

\section{Budaya Organisasi dan Kepemimpinan}
A. Pengertian dan ruang lingkup budaya organisasi dan kepemimpinan 1
B. Budaya Organisasi dan Sosialisasi 16
C. Revolusi Budaya 21
D. Aspek-aspek kepemimpinan 32
E. Jenis-jenis kepemimpinan 35

\section{BAB 2}

\section{Perilaku Individu dan Perilaku Kerja}
A. Pengertian Perilaku Individu dan Perilaku Kerja 42
B. Mengelola Perilaku Individu 54
C. Rancangan Pekerjaan dan Pekerjaan 63

\section{BAB 3}

\section{Persepsi, Atribut dan Emosi}

A. Konsep pengertian, persepsi pengaruh buruk, stereotip dan distorsi 68

B. Teori Atribusi 92

C. Emosi 104 
BAB 4

\section{Evaluasi, Umpan Balik, Penghargaan}
A. Konsep Evaluasi Kinerja 108
B. Umpan Balik 121
C. Reinforcement 123
D. Penghargaan 126

\section{BAB 5}

\section{Motivasi}
A. Komponen pembentuk motivasi 135
B. Teori Motivasi 138

\section{BAB 6}

\section{Kelompok dan Tim}
A. Perbedaan Kelompok dan Tim 141
B. Karakteristik Kelompok 156
C. Jenis-Jenis Kelompok 160
D. Tahap Pembentukan Kelompok 163

\section{BAB 7}
A. Jenis-jenis konflik 166
B. Penyebab konflik antar kelompok 170
C. Mengeola Konflik 180 
BAB 8

\section{Kekuasaan Politik dan Pemberdayaan}
A. Konsep kekuasaan 185
B. Pemberdayaan 187
C. Strategi dan taktik politik 191
D. Etika, kekuasaan dan politik 201

\section{BAB 9}

\section{Negoisasi}
A. Jenis-jenis negoisasi 227
B. Cara peningkatan proses negoisasi 233

\section{BAB 10}

\section{Pengambilan Keputusan}
A. Jenis-jenis pengambilan keputusan 235
B. Proses pengambilan keputusan 241
C. Pengaruh perilaku dalam pengambilan keputusan 247 


\section{BAB 1}

\section{Budaya Organisasi dan Kepemimpinan}

\section{A. Pengertian Dan Ruang Lingkup Budaya Organisasi Dan Kepemimpinan}

1. Ruang Lingkup Budaya Organisasi

Budaya Organisasi adalah sistem yang diikuti oleh sekelompok orang yang mengikat kelompok tersebut menjadi sebuah satu kesatuan yang terikat pada peraturan tertentu yang dibuat berdasarkan kesepakatan yang dirumuskan secara bersama serta memiliki kaidah pada nilai-nilai tertentu. Definisi ini menunjukkan bahwa kebudayaan itu melaksanakan fungsi-fungsi penting dalam organisasi. Budaya organisasi yang kuat sangat berpengaruh terhadap kinerja karyawan dibanding budaya organisasi yang lemah. Semakin para karyawan menerima nilai-nilai utama organisasi dan semakin terlibat mereka dalam nilainilai itu, semakin kuatlah budaya organisasi.

Budaya organisasi itu kuat atau lemah diantaranya tergantung pada faktor-faktor seperti ukuran organisasi itu, berapa lama organisasi itu telah berdiri, berapa banyak angka pergantian di antara karyawan, dan intensitas asal mula budaya tersebut. Dalam organisasi-organisasi tertentu, tidaklah jelas apa yang penting dan apa yang tidaksuatu ciri budaya lemah. Dalam organisasi-organisasi seperti itu, budaya kiranya kurang mempengaruhi para manajer. Namun, kebanyakan organisasi memiliki budaya yang moderat hingga kuat. Relatif terdapat kesepakatan yang besar mengenai apa yang penting, apa yang 
menentukan tingkah laku karyawan yang "baik", apa yang dibutuhkan untuk naik pangkat, dan sebagainya. Dalam kenyataannya, salah satu kajian budaya organisasi menemukan bahwa para karyawan di perusahaanperusahaan yang budayanya kuat lebih terlibat dengan perusahaan mereka daripada karyawan-karyawan di perusahaan-perusahaan yang budayanya lemah. Perusahaan-perusahaan dengan budaya organisasi yang kuat biasanya menggunakan usaha-usaha perekrutan dan praktek-praktek sosialisasi untuk membina keterlibatan karyawan.

Hal senada juga ditelaah oleh Kolb, Osland dan Rubin, mereka menyatakan bahwa budaya organisasi adalah model asumsi-asumsi dasar yang memberikan kelompok yang mengungkapkan dan menemukan atau mengembangkan didalam pengajaran untuk mengatasi masalah-masalah penyesuaian ke luar (external adaptation) dan integrasi ke dalam (internal integration) dan bekerja dengan cukup baik sebagai pertimbangan yang sah, serta untuk mengajarkan kepada anggota-anggota baru sebagai cara yang benar untuk mengatasi, memikirkan dan merasakan dalam hubungannya dengan masalah-masalah tersebut(Kolb : 2005).

Susanto memberikan deskripsi tentang budaya organisasi bahwa nilai-nilailah yang menjadi pedoman dasar dari segala sumber daya manusia yang mereka gunakan untuk mengatasi berbagai masalah yang terjadi pada kehidupan mereka. Hal ini baik yang berupa masalah eksternal maupun internal dengan usaha penyesuaian integrasi hubungan dengan perusahaan dimana mereka berada dengan memahami nilai-nilai yang telah ditentukan 
dan mereka berkewajiban untuk bertindak sesuai dengan nilai tersebut.

Secara keseluruhan dapat disampaikan bahwa budaya organisasi merupakan kesatuan padu suatu kelompok dalam sebuah organisasi berakarkan pada nilai-nilai yang diagungkan atau pada asumsi-asumsi yang dibuat, disetujui, serta diakui oleh seluruh anggota kelompok tersebut. Perilaku-perilaku yang berlandaskan pada nilai-nilai ini selanjutnya menjadi sebuah kebiasaan yang mencirikan kekhasan suatu organisasi tersebut. Nilai-nilai maupun asumsi yang dijalankan dengan baik akan memberikan timbal balik yang baik pula terhadap keberlangsungan organisasi tersebut.

2. Ruang Lingkup Kepemimpinan

Menurut sejarah, masa "kepemimpinan" muncul pada abad $18 . \quad$ Ada beberapa pengertiannkepemimpinan, mantaramlain:

1. Kepemimpinan adalah pengaruh antar pribadi, dalam situasi tertentu dan langsung melalui proses komunikasi untuk mencapai satu atau beberapa tujuan tertentu (Tannebaum, Weschler and Nassarik, 1961, 24).

2. Kepemimpinan adalah sikap pribadi, yang memimpin pelaksanaan aktivitas untuk mencapai tujuan yang diinginkan. (Shared Goal, Hemhiel \& Coons, 1957, 7).

3. Kepemimpinan adalah suatu proses yang mempengaruhi aktifitas kelompok yang diatur untuk mencapai tujuan bersama (Rauch \& Behling, 1984, 46) 
4. Kepemimpinan adalah kemampuan seni atau tehnik untuk membuat sebuah kelompok atau orang mengikuti dan menaati segala keinginannya.

5. Kepemimpinan adalah suatu proses yang memberi arti (penuh arti kepemimpinan) pada kerjasama dan dihasilkan dengan kemauan untuk memimpin dalam mencapai tujuanm(Jacobsm\&mJacques,m1990,m281).

Banyak definisi kepemimpinan yang menggambarkan asumsi bahwa kepemimpinan dihubungkan dengan proses mempengaruhi orang baik individu maupun masyarakat. Dalam kasus ini, dengan sengaja mempengaruhi dari orang ke orang lain dalam susunan aktivitasnya dan hubungan dalam kelompok atau organisasi. John C. Maxwell mengatakan bahwa inti kepemimpinan adalah mempengaruhi atau mendapatkanmpengikut.

Menurut James A.F Stonen, tugas utama seorang pemimpin adalah:

1. Seorang pemimpin bertanggung jawab untuk bekerja dengan orang lain, salah satu dengan atasannya, staf, teman sekerja atau atasan lain dalam organisasi sebaik orang diluar organisasi.

2. Seorang pemimpin bertanggungjawab untuk menyusun tugas menjalankan tugas, mengadakan evaluasi, untuk mencapai outcome yang terbaik. Pemimpin bertanggung jawab untuk kesuksesan stafnya tanpa kegagalan

3. Proses kepemimpinan dibatasi sumber, jadi pemimpin harus dapat menyusun tugas dengan mendahulukan prioritas. Dalam upaya pencapaian tujuan pemimpin harus dapat mendelegasikan tugas-tugasnya kepada staf. 
Kemudian pemimpin harus dapat mengatur waktu secara efektif,dan menyelesaikan masalah secara efektif.

4. Seorang pemimpin harus menjadi seorang pemikir yang analitis dan konseptual. Selanjutnya dapat mengidentifikasi masalah dengan akurat. Pemimpin harus dapat menguraikan seluruh pekerjaan menjadi lebih jelas dan kaitannya dengan pekerjaan lain.

5. Konflik selalu terjadi pada setiap tim dan organisasi. Oleh karena itu, pemimpin harus dapat menjadi seorang mediator (penengah)

6. Seorang pemimpin harus mampu mengajak dan melakukan kompromi. Sebagai seorang diplomat, seorang pemimpin harus dapat mewakili tim atau organisasinya.

7. Seorang pemimpin harus dapat memecahkan masalah.

Menurut Henry Mintzberg, Peran Pemimpin adalah :

1. Peran hubungan antar perorangan, dalam kasus ini fungsinya sebagai pemimpin yang dicontoh, pembangun tim, pelatih, direktur, mentor konsultasi.

2. Fungsi Peran informal sebagai monitor, penyebar informasi dan juru bicara.

3. Peran Pembuat keputusan, berfungsi sebagai pengusaha, penanganan gangguan, sumbermalokasi,mdanmnegosiator.

Pemimpin adalah inti dari manajemen. Ini berarti bahwa manajemen akan tercapai tujuannya jika ada pemimpin. Kepemimpinan hanya dapat dilaksanakan oleh seorang pemimpin. Seorang pemimpin adalah seseorang yang mempunyai keahlian memimpin, mempunyai kemampuan mempengaruhi pendirian/pendapat orang atau 
sekelompok orang tanpa menanyakan alasan-alasannya. Seorang pemimpin adalah seseorang yang aktif membuat rencana-rencana, mengkoordinasi, melakukan percobaan dan

memimpin pekerjaan untuk mencapai tujuan bersa ma-sama.

Kepemimpinan adalah kegiatan mempengaruhi perilaku orang-orang lain agar mau bekerjasama untuk mencapai tujuan tertentu. Definisi itu mengandung dua pengertian pokok yang sangat penting tentang kepemimpinan, yaitu Mempengaruhi perilaku orang lain. Kepe-mimpinan dalam organisasi diarahkan untuk mempengaruhi orang-orang yang dipimpinnya, agar mau berbuat seperti yang diharapkan ataupun diarahkan oleh orang yang memimpinnya.

Motivasi orang untuk berperilaku ada dua macam, yaitu motivasi ekstrinsik dan motivasi intrinsik. Dalam hal motivasi ekstrinsik perlu ada faktor di luar diri orang tersebut yang mendorongnya untuk berperi-laku tertentu. Dalam hal semacam itu kepemimpinan adalah faktor luar. Sedang motivasi intrinsik daya dorong untuk berperilaku tertentu itu berasal dari dalam diri orang itu sendiri. Jadi semacam ada kesadaran kemauan sendiri untuk berbuat sesuatu, misalnya memperbaiki mutu kerjan ya.

Dalam proses tersebut pimpinan membimbing, memberi pengarahan, mempengaruhi perasaan dan perilaku orang lain, memfasilitasi serta menggerakkan orang lain untuk 
bekerja menuju sasaran yang diingini bersama. Semua yang dilakukan pimpinan harus bisa dipersepsikan oleh orang lain dalam organisasinya sebagai bantuan kepada orang-orang itu untuk dapat meningkatkan mutu kinerjanya. Dalam hal ini usaha mempengaruhi perasaan mempunyai peran yang sangat penting. Perasaan dan emosi orang perlu disentuh dengan tujuan untuk menumbuhkan nilai-nilai baru, misalnya bekerja itu harus bermutu, atau memberi pelayanan yang sebaik mungkin kepada pelanggan itu adalah suatu keharusan yang mulia, dan lain sebagainya. Dengan nilai-nilai baru yang dimiliki itu orang akan tumbuh kesadarannya untuk berbuat yang lebih bermutu. Dalam ilmu pendidikan ini masuk dalam kawasan affective.

\section{Pandangan Kepemimpinan}

1. Seorang yang belajar seumur hidup

Tidak hanya melalui pendidikan formal, tetapi juga diluar sekolah. Contohnya, belajar melalui membaca, menulis, observasi, dan mendengar. Mempunyai pengalaman yang baik maupun yang buruk sebagai sumber belajar.

2. Berorientasi pada pelayanan

Seorang pemimpin tidak dilayani tetapi melayani, sebab prinsip pemimpin dengan prinsip melayani berdasarkan karir sebagai tujuan utama. Dalam memberi pelayanan, pemimpin seharusnya lebih berprinsip pada pelayanan yang baik.

3. Membawa energi yang positif

Setiap orang mempunyai energi dan semangat.

Menggunakan energi yang positif didasarkan pada keikhlasan dan keinginan mendukung kesuksesan orang 
lain. Untuk itu dibutuhkan energi positif untuk membangun hubungan baik. Seorang pemimpin harus dapat dan mau bekerja untuk jangka waktu yang lama dan kondisi tidak ditentukan.

4. Percaya pada orang lain

Seorang pemimpin mempercayai orang lain termasuk staf bawahannya, sehingga mereka mempunyai motivasi dan mempertahankan pekerjaan yang baik. Oleh karena itu, kepercayaan harus diikuti dengan kepedulian.

5. Keseimbangan dalam kehidupan Seorang pemimpin harus dapat menyeimbangkan tugasnya. Berorientasi kepada prinsip kemanusiaan dan keseimbangan diri antara kerja dan olah raga, istirahat dan rekreasi. Keseimbangan juga berarti seimbang antara kehidupan dunia dan akherat.

6. Melihat kehidupan sebagai tantangan Kata 'tantangan' sering di interpretasikan negatif. Dalam hal ini tantangan berarti kemampuan untuk menikmati hidup dan segala konsekuensinya. Sebab kehidupan adalah suatu tantangan yang dibutuhkan, mempunyai rasa aman yang datang dari dalam diri sendiri. Rasa aman tergantung pada inisiatif, ketrampilan, kreatifitas, kemauan, keberanian, dinamisasi dan kebebasan.

7. Sinergi

Orang yang berprinsip senantiasa hidup dalam sinergi dan satu katalis perubahan. Mereka selalu mengatasi kelemahannya sendiri dan lainnya. Sinergi adalah kerja kelompok dan memberi keuntungan kedua belah pihak. Menurut The New Brolier Webster International Dictionary, Sinergi adalah satu kerja kelompok, yang mana memberi hasil lebih efektif dari pada bekerja secara 
perorangan. Seorang pemimpin harus dapat bersinergis dengan setiap orang atasan, staf, teman sekerja.

8. Latihan mengembangkan diri sendiri

Seorang pemimpin harus dapat memperbaharui diri sendiri untuk mencapai keberhasilan yang tinggi. Jadi dia tidak hanya berorientasi pada proses. Proses daalam mengembangkan diri terdiri dari beberapa komponen yang berhubungan dengan:

- Pemahaman materi;

- Memperluas materi melalui belajar dan pengalaman

- Mengajar materi kepada orang lain;

- Mengaplikasikan prinsip-prinsip;

- Memonitoring hasil;

- Merefleksikan kepada hasil;

- Menambahkan pengetahuan baru yang diperlukan materi;

- Pemahaman baru; dan

- Kembali menjadi diri sendiri lagi.

Mencapai kepemimpinan yang berprinsip tidaklah mudah, karena beberapa kendala dalam bentuk kebiasaan buruk, misalnya:

1. Kemauan dan keinginan sepihak;

2. Kebanggaan dan penolakan; dan

3. Ambisi pribadi.

Untuk mengatasi hal tersebut, memerlukan latihan dan pengalaman yang terus-menerus. Latihan dan pengalaman sangat penting untuk mendapatkan perspektif baru yang dapat digunakan sebagai dasar dalam pengambilan keputusan. 
Hukum alam tidak dapat dihindari dalam proses pengembangan pribadi. Perkembangan intelektual seseorang seringkali lebih cepat dibanding perkembangan emosinya. Oleh karena itu, sangat disarankan untuk mencapai keseimbangan diantara keduanya, sehingga akan menjadi faktor pengendali dalam kemampuan intelektual. Pelatihan emosional dimulai dari belajar mendengar. Mendengarkan berarti sabar, membuka diri, dan berkeinginan memahami orang lain. Latihan ini tidak dapat dipaksakan. Langkah melatih pendengaran adalah bertanya, memberi alasan, memberi penghargaan, mengancam dan mendorong. Dalam proses melatih tersebut, seseorang memerlukan pengontrolan diri, diikuti dengan memenuhi keinginan orang.

Mengembangkan kekuatan pribadi akan lebih menguntungkan dari pada bergantung pada kekuatan dari luar. Kekuatan dan kewenangan bertujuan untuk melegitimasi kepemimpinan dan seharusnya tidak untuk menciptakan ketakutan. Peningkatan diri dalam pengetahuan, ketrampilan dan sikap sangat dibutuhkan untuk menciptakan seorang pemimpin yang berpinsip karena seorang pemimpin seharusnya tidak hanya cerdas secara intelektual, tetapi juga emosional (IQ, EQ dan SQ).

Kepemimpinan Manajemen tidak selalu membuat keputusan sendiri dalam segala hal, tetapi hanya melakukannya dalam hal-hal yang akan lebih baik kalau dia yang memutuskannya. Sisanya diserahkan wewenangnya kepada ke-lompok-kelompok yang ada di bawah 
pengawasannya. Hal ini dilakukan terutama untuk hal-hal yang menyangkut cara melaksanakan pekerjaan secara teknis. Orang-orang yang ada dalam kelompok-kelompok kerja yang sudah mendapatkan pelatihan dan sehari-hari melakukan pekerjaan itulah yang lebih tahu bagaimana melakukan pekerjaan dan karenanya menjadi lebih kompeten untuk membuat keputusan dari pada sang pimpinan.

Setiap upaya meningkatkan mutu kinerja, apakah itu dalam mengha-silkan barang atau menghasilkan jasa, pada dasarnya selalu diperlukan adanya perubahan cara kerja. Jadi kalu diinginkan adanya mutu yang lebih baik jangan takut menghadapi perubahan, se-bab tanpa perubahan tidak akan terjadi peningkatan mutu kinerja. Perubahan bisa diciptakan oleh pemimpin, tetapi tidak perlu harus selalu berasal dari pimpinan, sebab kemampuan pemimpinpun terbatas. Oleh karena itu pemimpin justru perlu merangsang timbulnya kreativitas di ka-langan orang-orang yang dipimpinnya guna menciptakan hal-hal baru yang sekiranya akan menghasilkan kinerja yang lebih bermutu. Seorang pemimpin tidak selayaknya memaksakan ide-ide lama yang sudah terbukti tidak dapat menghasilkan mutu kinerja seperti yang diharap-kan. Setiap ide baru yang dimaksudkan untuk menghasilkan sesuatu yang lebih bermutu dari manapun asalnya patut disambut baik. Orangorang dalam organisasi harus dibuat tidak takut untuk berkreasi, dan orang yang terbukti menghasilkan ide yang bagus harus diberi pengakuan dan penghargaan.

Seorang pimpinan Manajemen selalu mendambakan 
pembaharuan, sebab dia tahu bahwa hanya dengan pembaharuan akan dapat dihasilkan mutu yang lebih baik. Oleh karena itu dia harus selalu mendorong semua orang dalam organisasinya untuk berani melakukan inovasiinovasi, baik itu menyangkut cara kerja maupun barang dan jasa yang dihasilkan. Tentu semua itu dilakukan melalui proses uji coba dan evaluasi secara ketat sebelum diadopsi secara luas dalam organisasi. Sebaliknya seo-rang pimpinan tidak sepatutnya mempertahankan kebiasaan-kebiasaan kerja lama yang sudah terbukti tidak menghasilkan mutu seperti yang diharapkan olah organisasi maupun oleh para pe-langgannya. Manajemen selalu mengupayakan adanya kerjasama dalam tim, kelompok, atau dalam unit-unit organisasi. Program-program mulai dari tahap perencanaan sampai ke pelaksanaan dan evaluasinya dilaksanakan melalui kerjasama, dan bukan

Pemimpin Manajemen selalu bertindak proaktif yang bersifat preventif dan an-tisipatif. Pemimpin Manajemen tidak hanya bertindak reaktif yang mulai mengambil tindakan bila su-dah terjadi masalah. Pimpinan yang proaktif selalu bertindak untuk mencegah munculnya masalah dan kesulitan di masa yang akan datang. Setiap rencana tindakan sudah difikirkan akibat dan konsekuensi yang bakal muncul, dan kemudian difikirkan bagaimana cara untuk mengeliminasi hal-hal yang bersifat negatif atau sekurang berusaha meminimalkannya. Dengan demikian ke-hidupan organisasi selalu dalam pengendalian pimpinan dalam arti semua sudah dapat diper-hitungkan sebelumnya, dan bukannya memungkinkan munculnya masalah-masalah secara me-ngejutkan dan menimbulkan kepanikan dalam 
organisasi. Tindakan yang reaktif biasanya sudah terlambat atau setidaknya sudah sempat menimbulkan kerugian atau akibat

lainnya.

Sudah dikatakan sebelumnya bahwa orang adalah sumberdaya yang paling utama dan paling berharga dalam setiap organisasi. Oleh karena itu SDM harus selalu mendapat perhatian yang besar dari pimpinan Manajemen dalam arti selalu diupa-yakan untuk lebih diberdayakan agar kemampuan-kemampuannya selalu meningkat dari waktu ke waktu. Dengan kemampuan yang meningkat itulah SDM itu dapat diharapkan untuk mening-katkan mutu kinerjanya. Program-program pelatihan, pendidikan dan lain-lain kegiatan yang bersifat memberdayakan SDM harus dilembagakan dalam arti selalu direncanakan dan dilaksanakan bagi setiap

orang secara bergiliran sesuai keperluan dan situasi

Bila berbicara tentang mutu tentu akan terlintas adanya mutu yang tinggi dan mutu yang rendah. Bila dikatakan bahwa kinerja suatu organisasi itu tinggi tentu karena dibandingkan dengan mutu organisasi lain yang kenyataannya lebih rendah. Artinya mutu tentang segala sesuatu itu sifatnya relatif, bukan absolut. Setidaknya begitulah pengertian mutu menurut Manajemen. Pimpinan dalam Manajemen dianjurkan melakukan pem-bandingan dengan organisasi lain, membandingkan mutu organisasinya dengan mutu organisasi lain yang sejenis. Kegiatan ini disebut benchmarking. Pimpinan Manajemen selalu berusaha menya-mai mutu kinerja organisasi lain dan kalau bisa bahkan berusaha melampaui mutu organisasi 
lain. Bila pimpinan berbicara tentang mutu organisasi lain dan kemudian ingin menyamai atau melebihi mutu organisasi lain itu, berarti pmpinan itu berbicara tentang persaingan. Setiap organisasi berusaha mendapatkan pelanggan yang lebih banyak dan yang berciri lebih baik. Usaha ini hanya akan berhasil kalau organisasi itu mampu berkinerja yang mutunya lebih tinggi dari organisasi lain. Ini persaingan. Manajemen dikembangkan untuk memenangkan persaingan. Oleh karena itu pimpinan Manajemen selalu harus menyadari adanya persaingan dan berbicara tentang itu dengan orang-orang dalam organisasinya.

Karakter suatu organisasi tercermin dari pola sikap dan perilaku orang-orangnya. Sikap dan perilaku organsasi yang cenderung menim-bulkan rasa senang dan puas pada fihak pelanggan-pelanggannya perlu dibina oleh pimpinan. Demikian pula budaya organisasi yang menjunjung tinggi nilai-nilai tertentu yang relevan dengan mutu yang diinginkan oleh organisasi itu juga perlu dibina. Misalnya dalam lembaga pendidikan perlu dikembangkan budaya yang menjunjung tinggi nilai-nilai belajar, kejujuran, kepelayanan, dan sebagainya.

Nilai-nilai yang merupakan bagian dari budaya organisasi itu harus menjadi pedoman dalam bersikap dan berperilaku dalam organisasi. Namun demikian ka-rakter dan budaya organisasi itu hanya akan tumbuh dan berkembang bila iklim organisasi itu menunjang. Olah karena itu pimpinan juga harus selalu membina iklim organisasinya agar kondusif bagi tumbuh dan berkembangnya karakter dan 
budaya organisasi tadi. Misalnya dengan menciptakan dan melaksanakan sistem penghargaan yang mendorong orang untuk bekerja dan berprestasi lebih baik. Atau pimpinan yang selalu berusaha berperilaku sedemikian rupa hingga dapat menjadi model yang selalu dicontoh oleh orangorang lain.

Pemimpin Manajemen tidak berusaha memusatkan kepemimpinan pada dirinya, tetapi akan menyebarkan kepemimpinan itu pada orang-orang lain, dan hanya menyisakan pada dirinya yang memang harus dipegang oleh seorang pimpinan. Kepemimpinan yang dimaksudkan adalah pengambilan keputusan dan pengaruh pada orang lain. Pengambilan tentang kebijaksanaan organisasi tetap ditangan pimpinan-atas, dan lainnya yang bersifat operasional atau bersifat teknis disebarkan kepada orangorang lain sesuai dengan kedudukan dan tugasnya. Dalam banyak hal bahkan pengambilan keputusan itu diserahkan kepada tim atau kelompok kerja tertentu.

Dengan demikian ketergantungan organisasi pada pimpinan akan sangat kecil, tetapi sebagian besar dari orang-orang dalam organisasi itu memiliki kemandirian yang tinggi. Kondisi semacam ini tentu saja akan tercapai melalui penerapan Manajemen yang baik dan benar, dan setelah melalui proses pembinaan yang panjang. Makin banyak dari kesepuluh ciri itu yang diterapkan oleh pimpinan Manajemen semakin baiklah mutu kepemimpinannya, dalam arti makin baiklah suasana kerja yang kondusif untuk terciptanya mutu, dan makin kuatlah dorongan yang diberikan kepada orang-orang dalam organisasinya untuk 
meningkatkan mutu kinerjanya. Kesepuluh hal tersebut perlu dihayati dan di-praktekkan oleh semua pimpinan, dari yang tertinggi sampai yang terrendah, sehingga akhirnya akan menjelma menjadi pola tindak yang normatif dari semua unsur pimpinan.

B. Revolusi Budaya

Definisi ini menunjukkan bahwa kebudayaan itu melaksanakan fungsi-fungsi penting dalam organisasi. Budaya organisasi yang kuat sangat berpengaruh terhadap kinerja karyawan dibanding budaya organisasi yang lemah. Semakin para karyawan menerima nilai-nilai utama organisasi dan semakin terlibat mereka dalam nilai-nilai itu, semakin kuatlah budaya organisasi.

Budaya organisasi itu kuat atau lemah diantaranya tergantung pada faktor-faktor seperti ukuran organisasi itu, berapa lama organisasi itu telah berdiri, berapa banyak angka pergantian di antara karyawan, dan intensitas asal mula budaya tersebut. Dalam organisasi-organisasi tertentu, tidaklah jelas apa yang penting dan apa yang tidak-suatu ciri budaya lemah. Dalam organisasi-organisasi seperti itu, budaya kiranya kurang mempengaruhi para manajer. Namun, kebanyakan organisasi memiliki budaya yang moderat hingga kuat. Relatif terdapat kesepakatan yang besar mengenai apa yang penting, apa yang menentukan tingkah laku karyawan yang "baik", apa yang dibutuhkan untuk naik pangkat, dan sebagainya. Dalam kenyataannya, salah satu kajian budaya organisasi menemukan bahwa para karyawan di perusahaan-perusahaan yang budayanya kuat lebih terlibat dengan perusahaan mereka 
daripada karyawan-karyawan di perusahaan-perusahaan yang budayanya lemah. Perusahaan-perusahaan dengan budaya organisasi yang kuat biasanya menggunakan usaha-usaha perekrutan dan praktek-praktek sosialisasi untuk membina keterlibatan karyawan.

Hal senada juga ditelaah oleh Kolb, Osland dan Rubin, mereka menyatakan bahwa budaya organisasi adalah model asumsiasumsi dasar yang memberikan kelompok yang mengungkapkan dan menemukan atau mengembangkan didalam pengajaran untuk mengatasi masalah-masalah penyesuaian ke luar (external adaptation) dan integrasi ke dalam (internal integration) dan bekerja dengan cukup baik sebagai pertimbangan yang sah, serta untuk mengajarkan kepada anggota-anggota baru sebagai cara yang benar untuk mengatasi, memikirkan dan merasakan dalam hubungannya dengan masalah-masalah tersebut(Kolb : 2005).

Dengan kata lain budaya organisasi menyangkut nilai-nilai seperti agresif atau defensif, atau kebersamaan sehingga mengubah tantangan menjadi peluang atau menghadirkan yang terbaik. Budaya yang berkembang dan dikembangkan di lingkungan suatu organisasi yang kemudian diistilahkan sebagai budaya organisasi, meletakkan dasar bagi suatu pola menyangkut langkah-langkah yang diteladankan oleh para manajer, yang kemudian menurun kepada para penyelia hingga eselon terbawah (eselon IV) secara vertikal dan berkembang secara terus-menerus secara horisontal dalam kurun waktu tertentu.

Organisasi yang memiliki budaya yang kuat ditandai dengan adanya kecenderungan hampir semua manajer menganut bersama seperangkat nilai dan metode menjalankan usaha 
organisasi. Karyawan baru mengadopsi nilai-nilai ini dengan sangat cepat. Seorang eksekutif baru bisa saja dikoreksi oleh bawahannya, selain juga oleh bossnya, jika dia melanggar norma-norma organisasi. Gaya dan nilai dari suatu budaya yang cenderung tidak banyak berubah dan akar-akarnya sudah mendalam, walaupun terjadi penggantian manajer. Dalam organisasi dengan budaya yang kuat, karyawan cenderung berbaris mengikuti penabuh genderang yang sama. Nilai-nilai dan perilaku yang dianut bersama membuat orang merasa nyaman dalam bekerja, rasa komitmen dan loyalitas membuat orang berusaha lebih keras lagi. Dalam budaya yang kuat memberikan struktur dan kontrol yang dibutuhkan, tanpa harus bersandar pada birokrasi formal yang mencekik yang dapat menekan tumbuhnya motivasi dan inovasi.

Budaya yang strategis cocok secara eksplisit menyatakan bahwa arah budaya harus menyelaraskan dan memotivasi anggota, jika ingin meningkatkan kinerja organisasi. Konsep utama yang digunakan di sini adalah "kecocokan". Jadi, sebuah budaya dianggap baik apabila cocok dengan konteksnya. Adapun yang dimaksud dengan konteks bisa berupa kondisi obyektif dari organisasinya atau strategi usahanya.

Budaya yang adaptif berangkat dari logika bahwa hanya budaya yang dapat membantu organisasi mengantisipasi dan beradaptasi dengan perubahan lingkungan, akan diasosiasikan dengan kinerja yang superiror sepanjang waktu. Ralph Klimann menggambarkan budaya adaptif ini merupakan sebuah budaya dengan pendekatan yang bersifat siap menanggung resiko, percaya, dan proaktif terhadap kehidupan individu. Para anggota secara aktif mendukung usaha satu sama lain untuk 
mengidentifikasi semua masalah dan mengimplementasikan pemecahan yang dapat berfungsi. Ada suatu rasa percaya (confidence) yang dimiliki bersama. Para anggotanya percaya, tanpa rasa bimbang bahwa mereka dapat menata olah secara efektif masalah baru dan peluang apa saja yang akan mereka temui. Kegairahan yang menyebar luas, satu semangat untuk melakukan apa saja yang dia hadapi untuk mencapai keberhasilan organisasi. Para anggota ini reseptif terhadap perubahan dan inovasi. Rosabeth Kanter mengemukakan bahwa jenis budaya ini menghargai dan mendorong kewiraswastaan, yang dapat membantu sebuah organisasi beradaptasi dengan lingkungan yang berubah, dengan memungkinkannya mengidentifikasi dan mengeksploitasi peluang-peluang baru. Contoh perusahaan yang mengembangkan budaya adaptif ini adalah Digital Equipment Corporation dengan budaya yang mempromosikan inovasi, pengambilan resiko, pembahasan yang jujur, kewiraswastaan, dan kepemimpinan pada banyak tingkat dalam hierarki.

Suatu budaya organisasi dapat menjadi kekuatan utama jika hadir secara konsisten timbal-balik dengan strategi organisasi yang ditempuh. Budaya organisasi yang kuat dapat menjadi pegangan yang mantap untuk, setiap pegawai yang bekerja di dalamnya dari lapisan teratas hingga lapisan terbawah. Budaya organisasi yang dijalankan oleh semua jajaran pegawai secara konsekuen dan konsisten,, dapat menciptakan kehidupan berorganisasi yang terbuka; pegawai bebas mengungkapkan pikiran dan perasaannya dan berpartisipasi dalam proses pengambilan keputusan manajerial. Budaya organisasi yang kuat dapat menciptakan rasa persatuan dan kesatuan jajaran pegawai dalam mewujudkan profesionalisme. Singkatnya budaya 
organisasi dapat menentukan dan mengarahkan sikap dan perilaku pegawai dalam melakukan tugasnya sehari-hari dan menciptakan suasana kerja yang menyenangkan hati, sehingga pegawai dapat bekerja lebih hemat dan produktif. Karena produktivitas yang merupakan fungsi dari tersedianya tenaga, teknologi, alat, dan dana, juga sangat dipengaruhi oleh semangat manusia yang melakukan tugas pekerjaan.

Stephen P. Robbins mengembangkan dimensi organisasi yang dapat dijadikan panduan dalam penelitian adalah sebagai berikut;

1. Inovasi dan pengambilan resiko. Artinya sejauhmana para anggota didorong agar inovatif dan siap mengambil resiko

2. Perhatian terhadap detail, maksudnya sejauhmana para anggota diharapkan memperlihatkan presisi, analisis, dan perhatian terhadap detail

3. Orientasi hasil dimaksudkan sejauhmana manajemen memusatkan perhatian pada hasil bukannya pada teknik dan proses yang digunakan untuk mencapai hasil itu

4. Orientasi orang diartikan sejauhmana keputusan manajemen memperhitungkan dampak hasil-hasil pada orang-orang di dalam organisasi itu

5. Orientasi tim merujuk pada sejauhmana kegiatan kerja diorganisasikan berdasar tim, bukannya berdasarkan individu

6. Keagresifan, tidak lain sejauhmana orang-orang itu agresif dan kompetitif dan bukannya santai-santai

7. Kemantapan, artinya sejauhmana kegiatan organisasi menekankan dipertahankannya status quo bukannya pertumbuhan. 
Dari uraian di atas, maka sintesis budaya organisasi adalah penilaian pegawai tentang nilai-nilai, norma, filosofi dan peraturan yang berlaku yang ada dalam kelompok pada lembaga untuk melaksanakan pekerjaan yang telah ditetapkan dalam upaya mendapat keberhasilan bersama. Adapun dimensi yang digunakan untuk mengukur budaya organisasi adalah 1) inovasi dan pengambilan resiko, dengan indikator kreativitas dan menciptakan suasana kerja, 2) perhatian terhadap detail, dengan indikator menyelesaikan tugas, melaporkan tugas, dan mengevaluasi pekerjaan, 3) orientasi hasil, yang meliputi pembagian hasil dan penguasaan bidang kerja, 4) orientasi orang, dengan indikator jenjang karier dan pengakuan keberadaan karyawan, 5) orientasi tim, dengan indikator kerjasama dengan orang lain dan tercapainya tujuan bersama, 6) keagresifan, dengan indikator persaingan kerja dan semangat kerja, dan 7) kemantapan, dengan indikator tanggungjawab terhadap pekerjaan dan kenyamanan dalam bekerja.

\section{Aspek-Aspek Kepemimpinan}

Banyak ilmuan dan ahli penelitian perilaku, memberikan batasan mengenai Kepemimpinan. Salah satu ilmuwan dan ahli penelitian perilaku yang telah memberikan batasan mengenai kepemimpinan, yaitu Ralp M. Stogdill (1971). Batasan yang diajukan adalah "Managerial leadership as the process of directing and influencing the task related activities of group members". Kepemimpinan manajerial sebagai proses pengarahan dan memengaruhi aktivitas yang dihubungkan dengan tugas dari para anggota kelompok. 
Berdasarkan batasan di atas, terdapat tiga implikasi penting yang perlu mendapat perhatian.

1. Kepemimpinan harus melibatkan orang lain atau bawahan. Karena kesanggupan mereka untuk menerima pengarahan dari manajer, para bawahan membantu menegaskan eksistensi manajer dan memungkinkan proses kepemimpinan.

2. Kepemimpinan mencakup distribusi otoritas yang tidak mungkin seimbang di antara manajer dan bawahan. Manajer memiliki otoritas untuk mengarahkan beberapa aktivitas pada bawahan, yang tidak mungkin dengan cara yang sama mengarahkan aktivitas manajer.

3. Disamping secara legal mampu memberikan para bawahan berupa perintah atau pengarahan, manajer juga dapat memengaruhi bawahan dengan berbagai sifat kepemimpinannya.

Mengacu pada pencapaian produkstivitas kerja yang maksimum, maka sebagai batasannya, kepemimpinan adalah : "Sifat dan perilaku untuk memengaruhi para bawahan agar mereka mampu berkeja sama sehingga membentuk jalinan kerja yang harmonis dengan pertimbangan aspek efisien dan efektif untuk mencapai tingkat produkstivitas kerja sesuai dengan yang telah ditetapkan".

a. Kualifikasi Seorang Pemimpin

Chester I. Barnard (1968) berpendapat bahwa kepemimpinan memiliki dua aspek diantaranya ;

1. Kelebihan individual dalam hal teknik kepemimpinan. Seseorang yang memiliki kondisi fisik yang baik, memiliki keterampilan yang tinggi, menguasai teknologi, memiliki persepsi yang tepat, memiliki 
pengetahuan yang luas, memiliki ingatan yang baik, serta imajinasi yang meyakinkan akan mampu memimpin bawahan,

2. Keunggulan pribadi dalam hal ketegasan, keuletan, kesadaran, dan keberhasilan.

Berbeda dengan Barnard, Hersey dan Bianchard (1980:9-10) mengklasifikasikan keahlian yang diperlukan bagi seorang manajer menjadi tiga tingkat sebagaimana berikut ini :

a). Mengerti Perilaku Masa Lampau (Understanding Past Behavior) Yang utama manajer harus mengerti mengapa orang berperilaku sebagaimana yang mereka lakukan. Perilaku orang dapat dipahami, sebaiknya dengan cara memahami perilaku orang pada masa lampau.

b). Memprediksi Perilaku Masa Depan (predicting Future Behavior) Pada dasarnya memahami perilaku masa lampau saja tidaklah cukup. Mungkin yang lebih penting adalah mampu memprediksi apakah yang akan mereka lakukan sekarang, besok, minggu depan, dan seterusnya pada kondisi lingkungan yang dinamis.

c). Pengarahan, Perubahan, dan Pengendalian Perilaku (Directing, Changing and Controlling Behavior)

Terlepas dari dua pendapat diatas, pada esensinya kualifikasi kepemimpinan yang memungkinkan seorang manajer memainkan perannya dalam menopang kondisi yang ada meliputi hal-hal berikut :

1. Watak dan Kepribadian yang Terpuji

Agar para bawahan maupun orang yang berada di luar organisasi mempercayainya, seorang manajer harus memiliki watak dan kepribadian yang terpuji. Manajer adalah cermin bawahan. Dan ia adalah sumber identifikasi, motivasi dan moral pada bawahan.

2. Prakarsa yang Tinggi 
Seorang pemimpin hendaknya seorang self starter, memiliki inisiatif sendiri. la mengajukan gagasan dan bersedia menanggung risiko kegagalan bersamaan dengan adanya kesempatan untuk memperoleh keberhasilan.

3. Hasrat Melayani Bawahan

Seorang pemimpin harus percaya pada bawahan, mendengarkan pendapat mereka, berkeinginan membantu, serta menimbulkan dan mengembangkan keterampilan agar karier mereka meningkat.

4. Sadar dan Paham Kondisi Lingkungan

Seorang manajer tidak hanya menyadari mengenai apa yang sedang terjadi di sekitarnya, tetapi juga harus memiliki pengertian yang memadai sehingga dapat mengevaluasi perbedaan kondisi lingkungan tersebut untuk kepentingan organisasi dan para bawahannya.

5. Intelegensi yang Tinggi

Seorang manajer harus memiliki kemampuan berpikir pada taraf yang tinggi. la dituntut untuk mampu menganalisis permasalahan dengan efektif, belajar dengan cepat, dan memiliki minat yang tinggi untuk mendalami dan menggali suatu ilmu pegetahuan.

6. Berorientasi ke masa depan

Seorang pemimpin harus memiliki intuisi, kemampuan memprediksi, dan visi sehingga dapat mengetahui sejak awal mengenai kemungkinan-kemungkinan apa yang dapat memengaruhi organisasi yang dikelola dan para bawah yang tergorganisir.

7. Sikap Terbuka dan Lugas

Seorang pemimpin harus memiliki sifat terbuka. la harus sanggup mempertimbangkan fakta dan inovasi yang baru. Lugas namun konsisten pendirianya. Bersedia mengganti 
cara kerja yang lama dengan cara kerja baru yang dipandang mampu memberikan nilai guna yang efisien dan efektif bagi organisasi yang dipimpinnya.

8. Widiasuara yang Efektif

Seorang manajer adalah penyampaian berita kepada orang lain. Vertikal ke bawah untuk memberikan instruksi dan perintah kepada bawahan, dan horizontal kepada pihak-pihak yang memiliki transaksi dengan organisasi. Keterampilan memainkan peran dalam hal ini sangat membantu efektivitas organisasi yang dipimpinnya.

Tabel 1 : Kualifikasi Pemimpin

\begin{tabular}{|c|c|c|}
\hline Pengembang & $\begin{array}{c}\text { Kualifikasi Yang } \\
\text { Harus Dimiliki }\end{array}$ & Aspek-Aspek Spesifik \\
\hline \multirow[t]{2}{*}{$\begin{array}{l}\text { Chester } \\
\text { Barnard }\end{array}$} & $\begin{array}{l}\text { Kelebihan } \\
\text { individual teknik } \\
\text { kepemimpinan }\end{array}$ & $\begin{array}{l}\text { Kondisi fisik yang baik } \\
\text { Keterampilan yang tinggi } \\
\text { Menguasai teknologi } \\
\text { Memiliki persepsi yang } \\
\text { tepat } \\
\text { Memiliki pengetahuan } \\
\text { yang luas } \\
\text { Memiliki ingatan yang baik } \\
\text { Imanjinasi yang } \\
\text { meyakinkan }\end{array}$ \\
\hline & $\begin{array}{l}\text { Keunggulan } \\
\text { Pribadi }\end{array}$ & $\begin{array}{l}\text { Ketegasan } \\
\text { Keuletan } \\
\text { Kesadaran } \\
\text { Keberhasilan }\end{array}$ \\
\hline
\end{tabular}




\begin{tabular}{|c|c|c|}
\hline \multirow[t]{3}{*}{$\begin{array}{l}\text { Hersey dan } \\
\text { Balnchard }\end{array}$} & $\begin{array}{l}\text { Mengerti } \\
\text { perilaku masa } \\
\text { lampau }\end{array}$ & $\begin{array}{l}\text { Memahami apa yang } \\
\text { dilakukan bawahan pada } \\
\text { masa yang lalu } \\
\text { Memahami apa yang akan } \\
\text { dilakukan sekarang, besok, } \\
\text { dan waktu yang akan } \\
\text { datang }\end{array}$ \\
\hline & $\begin{array}{l}\text { Memprediksi } \\
\text { perilaku masa } \\
\text { depan }\end{array}$ & $\begin{array}{l}\text { Mampu mengembangkan } \\
\text { perilaku untuk } \\
\text { memengaruhi bawahan }\end{array}$ \\
\hline & $\begin{array}{l}\text { Pengarahan, } \\
\text { perubahan, dan } \\
\text { pengendalian } \\
\text { perilaku }\end{array}$ & \\
\hline \multirow[t]{4}{*}{ MBS } & $\begin{array}{l}\text { Watak dan } \\
\text { kepribadian yang } \\
\text { tepuji }\end{array}$ & $\begin{array}{l}\text { Sebagai cermin bawahan } \\
\text { harus dapat dijadikan } \\
\text { sumber identifikasi, } \\
\text { motivasi, dan moral. }\end{array}$ \\
\hline & $\begin{array}{l}\text { Prakrsa yang } \\
\text { tinggi }\end{array}$ & $\begin{array}{l}\text { Inisatif } \\
\text { Gagasan } \\
\text { Kesediaan menanggung } \\
\text { kegagalan }\end{array}$ \\
\hline & $\begin{array}{l}\text { Hasrat melayani } \\
\text { bawahan }\end{array}$ & $\begin{array}{l}\text { Percaya kepada bawahan } \\
\text { Selalu mendengarkan } \\
\text { pendapat } \\
\text { Keinginan membantu } \\
\text { bawahan }\end{array}$ \\
\hline & $\begin{array}{l}\text { Intelegensi yang } \\
\text { tinggi }\end{array}$ & $\begin{array}{l}\text { Mampu menganalisis } \\
\text { permasalahan } \\
\text { Belajar dengan cepat }\end{array}$ \\
\hline
\end{tabular}




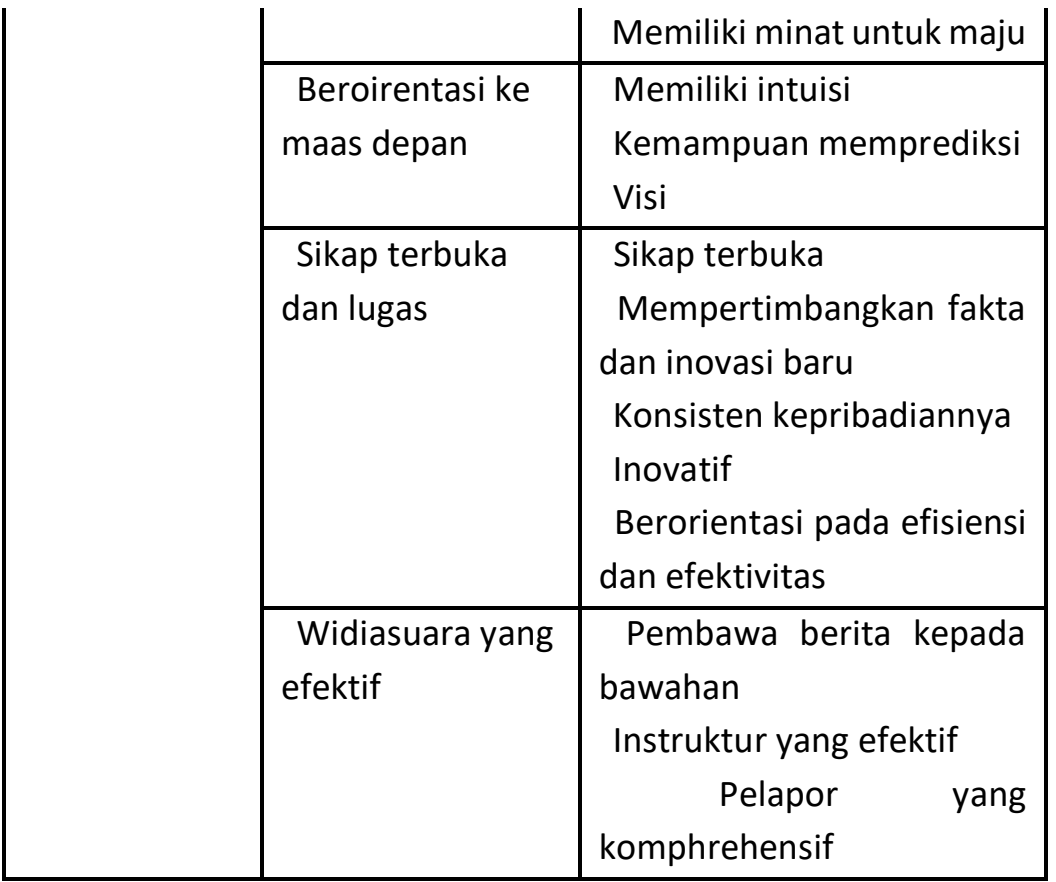

b. Tipe Kepemimpinan Dalam Organisasi

G.R Terry (1960) sebagai salah seorang pengembang ilmu manjemen mengemukakan tipe kepemimpinan sebagai berikut :

1. Kepemimpinan Pribadi (Personal Leadership)

Seorang manajer dalam melaksanakan tindakannya selalu dilakukan dengan cara kontak pribadi. Intruksi disampaikan secara oral ataupun langsung pribadi disampaikan oleh manajer yang bersangkutan. Tipe kepemimpinan ini sering dianut oleh perusahaan kecil karena kompleksitas bawahan maupun kegiatannya sangatlah kecil. Akibatnya, pelaksanaannya selain mudah juga sangat efektif dan memang biasa dilakukan tanpa mengalami prosedural yang berbelit.

2. Kepemimpinan Nonpribadi (Nonpersonal Leadership) 
Segala peraturan dan kebijakan yang berlaku pada perusahaan melalui bawahannya atau menggunakan media nonpribadi, baik rencana, intruksi, maupun program penyeliaannya. Pada tipe ini, program pendelegasian kekuasaan sangatlah berperan dan harus diaplikasikan.

3. Kepemimpinan Otoriter (Authoritarian Leadership)

Manajer yang bertipe otoriter biasanya bekerja secara sungguh-sugguh, teliti, dan cermat. Manajer bekerja menurut peraturan dan kebijakan yang berlaku dengan ketat. Meskipun agak kaku dan segala instruksinya harus dipatuhi oleh para bawahan, para bawahan tidak berhak mengomentarinya. Karena manajer beranggapan bahwa dialah yang berhak sebagai pengemudi yang akan bertanggung jawab atas segala kompleksitas organisasi.

4. Kepemimpinan Demokratis (Democrative Leadership)

Pada kepemimpinan yang demokratis, manajer beranggapan bahwa ia merupakan bagian integral yang sama sebagai elemen perusahaan dan secara bersamaan seluruh elemen tersebut bertanggung jawab terhadap perusahaan. Oleh karen itu, agar seluruh bawahan merasa bertanggung jawab maka mereka harus berpartisipasi dalam setiap aktivitas perencanaan, evaluasi dan penyeliaan. Setiap individu bawahan merupakan potensi yang berharga dalam usaha merealisasikan tujuan.

5. Kepemimpinan Paternalistik (Paternalistic Leadership)

Kepemimpinan yang paternalistik dicirikan oleh suatu pengaruh yang bersifat kebapakan dalam hubungan antara manajer dengan perusahaan. Tujuannya adalah untuk melindungi dan memberikan arah, tindakan dan perilaku ibarat peran seorang bapak kepada anaknya.

6. Kepemimpinan Menurut Bakat (Indigenous Leadership) 
Tipe kepemimpinan menurut bakat biasanya muncul dari kelompok informal yang didapatkan dari pelatihan meskipun tidak langsung. Dengan adanya sistem persaingan, dapat menimbulkan perebedaan pendapat yang seru dari kelompok yang bersangkutan. Biasanya akan muncul pemimpin yang memiliki kelemahan diantara mereka yang ada dalam kelompok tersebut menurut keahliannya dimana ia terlibat di dalamnya. Pada situasi ini peran bakat sangat menonjol, sebagai dampak pembawaan sejak lahir dan mungkin disebabkan adanya faktor keturunan.

Berbeda dengan tipe kepemimpinan yang dikemukakan oleh G.R Terry, Robert Blake dan Jane S. Mouton (1964) yang mempopulerkan Managerial Grid dengan membagi lima tipe kepemimpinan (Hesey dan Blachard, 1980:96-97). Pembagian tersebut didasarkan pada bawahan. Kelima tipe kepemimpinan dijelaskan berikut ini :

1. Tandus (improverished)

Yaitu pemakaianusaha seminimum mungkin untuk menyelesaikan suatu pekerjaan guna mempertahankan keanggotaan dalam organisasi.

2. Perkumpulan (country club)

Yaitu menumpahkan perhatian kepada bawahan untuk memuaskan hubungan yang menggairahkan, suasana organisasi yang bersahabat, dan menggairahkan tempat kerja.

3. Tugas (task)

Yaitu efeisiensi dalam hasil pekerjaan yang diperoleh dari kondisi kerja yang tersusun dengan mengurangi campur tangan elemen manusia sampai pada tingkat minimun.

4. Jalan tengah (middle of road) 
Yaitu kecakapan organisasi yang memadai adalah usaha dan memungkinkan membuat keseimbangan diantara kerja yang dilakukan sambil memperhatikan semangat bawahan pada tingkat memuaskan.

5. Tim (team)

Yaitu penampungan kerja yang diperoleh dari persetujuan (commited) bawahan, yang paling saling bergantung pada pegangan umum yang sesuai dengan tujuan organisasi yang menjurus pada keyakinan dan penghargaan.

Tabel 2 : Perbandingan Tipe Kepemimpinan

\begin{tabular}{|l|l|}
\hline \multicolumn{2}{|c|}{ Tipe Kepemimpinan } \\
\hline \multicolumn{1}{|c|}{ G.R. Terry } & \multicolumn{1}{|c|}{ Blake Dan Mouton } \\
\hline Kepemimpinan pribadi & Tandus (improverished) \\
(personal leadership) & Perkumpulan (country club) \\
Kepemimpinan non pribadi & Tugas (task) \\
(nonpersonal leadership) & Jalan tengah (middle of read) \\
Kepemimpinan otoriter & Tim (team) \\
(authotitarian leadership) & \\
Kepemimpinan paternalistik & \\
(paternalistic leadership) & \\
Kepemimpinan menurut & \\
bakat (indigenous leadership) & \\
\hline
\end{tabular}

Tipe kepemimpinan diatas berlaku untuk berbagai tingkat kepemimpinan dalam organisasi. John C. Maxwell (1995) mengemukakan lima tingkat kepemimpinan yang disajikan pada gambar 8.1. 
c. Sumber Dan Dasar Otoritas Kepemimpinan

Dalam konsep manajemen, otoritas meliputi kemampuan untuk menggerakkan sumber daya alam maupun sumber daya manusia, mendapatkan dan menggunakannya untuk mencapai tujuan.

Amitai Etziomi (1961) membedakan sumber otoritas menjadi dua, yaitu :

1. Otoritas Posisi (Position Power)

otoritas posisi datang dari kantor manajer organisasi, otoritas posisi bersumber dari atas dan tidak bersama pada kantor. Manajer yang menduduki posisi dalam organisasi lebih kurang memiliki otoritas posisi.

2. Otoritas Pribadi (Personal Power).

otoritas pribadi adalah sejauh mana para bawahan respek, merasa senang dan percaya kepada pemimpin mereka, serta melihat tujuan mereka betul-betul dipuaskan melalui tujuan pemimpin. Otoritas pribadi dalam suatu organisasi bersumber dari bawah, yaitu dari pada bawahan.

Berbeda dengan Etziomi, French dan Raven (1960:607-623) mendeskripsikan bentuk otoritas yang dirasakan mungkin dimiliki oleh seorang pemimpin, yaitu sebagai berikut :

1. Otoritas Memaksa (Coervice Power)

Yaitu otoritas yang didasarkan atas rasa takut. Seorang bawahan merasa bahwa kegagalan memenuhi permintaan seorang pemimpin dapat menyebabkan dijatuhkannya suatu bentuk sanksi, peringatan, atau pengasingan sosial dari kelompok.

2. Otoritas Imbalan (Reward Power) 
Yaitu otoritas yang didasarkan atas harapan, menerima pujian, penghargaan, atau pendapatan bagi terpenuhinya pemintaan seorang pemimpin.

3. Otoritas Legitimasi (Legitimate Power)

Yaitu otoritas didasarkan atas keterampilan spesifik, keahlian, atau pengetahuan. Para bawahan menganggap bahwa pemimpin tersebut memiliki keahlian yang relevan dan yakin bahwa keahlian tersebut melebihi keahlian mereka sendiri.

4. Otoritas Ahli (Expert Power)

Yaitu otoritas didasarkan atas keterampilan spesifik, keahlian atau pengetahuan. Para bawahan menganggap bahwa pimpinan tersebut memiliki keahlian yang relevan dan yakin bahwa keahlian tersebut melebihi keahlian mereka sendiri.

5. Otoritas Referensi (Referent Power)

Yaitu otoritas yang didasarkan atas daya tarik. Seorang pemimpin yang dikagumi karena ciri khasnya memiliki otoritas referensi. Bentuk otoritas ini secara populer dinamakan kharisma. Pemimpin dikatakan memiliki kharisma untuk memberi semangat dan menarik para bawahan.

Apabila kelima sumber otoritas yang dikemukakan oleh French dan Raven di atas ditransfer ke dalam pembagian Etziomi, akan tampak bahwa otoritas memaksa dan otoritas imbalan berkaitan dengan otoritas posisi. Adapun otoritas legitimasi, otoritas ahli, dan otoritas referensi berkaitan dengan otoritas pribadi.

d. Delegasi Wewenang Bagi Kepemimpinan Yang Sukses Dan Kepemimpinan Yang Efektif.

Delegasi wewenang adalah pelimpahan atau pemberian otoritas dan tanggung jawab dari pimpinan atau kesatuan organisasi kepada seseorang atau kesatuan organisasi lain untuk melakukan aktivitas 
tertentu. Hal ini didasarkan bahwa pada esensinya hampir tidak ada seorang manajer yang dapat secara pribadi menyelesaikan secara penuh menyelia seluruh tugas organisasi. Dengan demikian, terlihat betapa pentingnya delegasi wewenang oleh manajer kepada bawahan demi efisiensi fungsi setiap organisasi.

Pada esensinya bahwa baik kepemimpinan yang sukses maupun kepemimpinan yang efektif melakukan delegasi wewenang meskipun kedua kepemimpinan tersebut frekuensi pelaksanaannya tidak sama. Karena memang keduanya berbeda. Kepemimpinan yang sukses tampak pada kepemimpinan manajer memengaruhi bawahan untuk mengerjakan suatu tugas. Apabila bawahan mengerjakan tugas tersebut dengan rasa ketidaksenangan, dan melakukan tugas tersebut hanya karena otoritas seorang manajer maka manajer tersebut sukses dalam kepemimpinannya. Akan tetapi, kepemimpinannya tidak efektif. Apabila bawahan merespon karena mereka ingin melakukan tugas tersebut dan menemukan kompensasinya, tetapi dari otoritas yang mempribadi, lalu bekerja menghormati, patuh, dan taat kepada manjer, dan dengan senang hati bekerja sama dengannya, kemudian merealisasikan bahwa permintaan manajer konsisten dengan beberapa tujuan pribadi bawahan. Hal inilah yang dimaksud dengan kepemimpinan yang efektif. Di sini, bawahan melihat tujuan pribadinya tersalur dengan menyelenggarakan aktivitas tersebut.

Oleh karena itu, dapat ditarik kesimpulan bahwa manajer dapat sukses dalam kepemimpinannya tetapi tidak efektif. Manajer tersebut hanya memiliki pengaruh yang relatif pendek terhadap sikap dan perilaku bawahan. Sebaliknya, manajer yang sukses kepemimpinannya dan efektif, pengaruh manajer tersebut cenderung jauh lebih lama dalam pengembangan dan kontinuitas organisasi. Pada dasarnya pelimpahan wewenang dan tanggung 
jawab baik bagi manajer yang sukses maupun manajer yang efektif didasarkan atas prinsip-prinsip sebagai berikut:

1. Agar organisasi dapat menggunakan sumber dayanya secara efisien, tanggung jawab atas tugas yang detail yang dilimpahkan kepada hierarki organisasi yang paling bawah yang mempunyai kemampuan dan informasi yang cukup untuk pelaksanaan tugas tersebut secara kompeten. Dampak yang diharapkan atas konsep ini adalah agar setiap individu dalam organisasi dapat melaksanakan tugas secara efektif, ia harus dilimpahkan wewenang dan tanggung jawab untuk melakukan hal itu.

2. Agar delegasi wewenang dan tanggung jawab berlangsung secara efektif, para anggota organisasi harus tahu eksistensi mereka dalam suatu rantai komando. Prinsip ini mempertegas bahwa dalam suatu organisasi harus terdapat suatu garis wewenang dan tanggung jawab yang jelas dan kronologis dari hierarki yang paling tinggi sampai pada hierarki yang paling rendah.

3. Agar delegasi wewenang dan tanggung jawab berlangsung secara efektif, setiap anggota organisasi harus melapor hanya kepada satu atasan. Melapor kepada lebih dari satu atasan mendorong individu untuk menghindar tanggung jawab karena dengan mudah individu tersebut menyalahkan kinerjanya yang rendah dengan alasan bahwa dengan beberapa atas berarti ia harus mengoperasikan beberpa pekerjaan yang diberikan kepadanya.

Dampak yang diperoleh atas delegasi yang efektif tersebut meliputi hal-hal berikut:

1. Semakin banyak tugas yang didelegasikan oleh manajer kepada bawahannya, semakin besar peluang baginya untuk 
mencari dan menerima tanggung jawab yang lebih besar dari manajer pada hierarki diatasnya.

2. Delegasi seringkali memungkinkan yang lebih baik karena para bawahan yang dekat dengan garis tembakan cenderung memiliki suatu pandangan yang lebih jelas mengenai fakta.

3. Seringkali delegasi yang dilakukan manajer secara efektif dapat memperlancar pengambilan keputusan

4. Delegasi menyebabkan bawahan untuk menerima tanggung jawab dan membuat pertimbangan sendiri.

e. Determinan Efektivitas Kepemimpinan

Kepemimpinan yang efektif menurut Chemers (1985 : 91-112) banyak bergantung pada beberapa variabel, seperti kultur organisasi, sifat dari tugas dan aktivitas kerja, dan nilai serta pengalaman manajerial. Determinan yang memengaruhi efektivitas kepemimpinan mencakup kepribadian, pengalaman masa lampau, dan harapan dari atasan ; kepribadian dan perilaku atasan ; karekteristik, harapan dan perilaku bawahan : persyaratan tugas; kultur dan kebijakan organisasi; harapan serta perilaku rekan sekerja.

1. Kepribadian, pengalaman masa lampau, dan harapan pemimpin (The Leader's Personality, Past Experiences, and Expectations)

2. Kepribadian dan Perilaku Atasan (The Expectations and Behavior of Superiors)

3. Karaketeristik, Harapan dan Perilaku Bawahan (Subordinates Characteristic, Expectations, and Behavior)

4. Persyaratan Tugas (task Requirement)

5. Kultur dan Kebijakan Organisasi (Organization Culture and Policies)

6. Harapan dan Perilaku Rekan (Peer Expectations and Behavior) 


\section{f. Teori Kepemimpinan Situasional}

Teori kepemimpinan situasional (situasional leadership theory) merupakan cabang dari model keefektifan manajer tiga dimensi (there dimensional manger effectiveness) yang didasarkan pada hubungan kurva linear diantara perilaku tugas serta perilaku hubungan dan kematangan. Pada model keefektifan manajer tiga dimensi telah ditambahkan dimensi efektivitas atas dimensi hubungan dan dimensi tugas. Dengan penambahan efektivitas tersebut maka modelnya berubah menjadi tiga dimensi, yaitu dimensi efektivitas, hubungan, dan tugas. Model ini mengintegrasikan konsep gaya manajer dengan tuntutan situasional suatu lingkungan yang spesifik. Apabila gaya manajer sesuai dengan stuasi yang dihadapi maka hal ini disebut efektif. Sebaliknya, apabila gaya manajer tidak sesuai dengan situasi yang dihadapi maka hal itu tidak efektif.

Teori kepemimpinan situasional mencoba menyiapkan manajer dengan beberapa pengertian mengenai hubungan diantara kepemimpinan yang efektif dan taraf kematangan (maturity) para pengikut mereka. Teori kepemimpinan situasional memberikan penjelasan bahwa taraf kematangan para bawahan secara kontinue meningkat dalam melaksanakan tugas yang spesifik. Manajer harus mengurangi perilaku tugas mereka dan meningkatkan perilaku hubungan sampai individu atau kelompok mencapai taraf kematangan moderat. Apabila individu atau kelompok mencari taraf kematangan diatas rata-rata, hal ini bagi manajer tidak hanya mengurangi perilaku tugas tetapi juga hubungan. Hal ini disebabkan individu atau kelompok tidak hanya matang dalam melaksanakan tugas tetapi juga matang secara psikologis. 
Pada gambar 2 terlihat bahwa titik potong terjadi dalam kuadran tugas tinggi dan hubungan rendah. Oleh karena itu, hendaknya manajer yang bekerja dengan bawahan yang mendemonstrasikan kematangan rendah harus memakai gaya yang bayak mengarahkan kepada anak buahnya. Meskipun perilaku hubungan rendah tidaklah berarti bahwa manajer tidak bersahabat atau tidak dapat bersifat informal terhadap organisasi yang dikelola, tetapi ketika memberikan penyeliaan kepada organisasi tersebut perlu lebih banyak waktu untuk mengarahkan mengenai apa yang akan dilakukan, bagaimana, dan dimana dibandingkan dengan memberikan dukungan dan penguatan yang bersifat sosioemosional. Apabila dengan cara tersebut tampak kematangan para bawahan meningkat, segera perilaku hubungan diperbesar. Dengan demikian titik berat gaya kepemimpinan akan bergerak dari 1 (tugas tinggi dan hubungan rendah) ke gaya 2 (tugas tinggi dan hubungan tinggi).

g. Sifat-sifat Pemimpin

Beberapa sifat yang biasanya melekat pada diri seorang pemimpin, diantaranya adalah sebagai berikut.

1. Intelejensi - Kemampuan bicara, menafsir, dan bernalar yang lebih kuat daripada para anggota yang dipimpin.

2. Kepercayaan Diri - Keyakinan akan kompetensi dan keahlian yang dimiliki

3. Determinasi - Hasrat untuk menyelesaikan pekerjaan yang meliputi ciri seperti berinisiatif, kegigihan, mempengaruhi, dan cenderung menyetir

4. Integritas - Kualitas kejujuran dan dapat dipercaya oleh para anggota 
5. Sosiabilitas - Kecenderungan pemimpin untuk menjalin hubungan yang menyenangkan, bersahabat, ramah, sopan, bijaksana, dan diplomatis. Menunjukkan rasa sensitif terhadap kebutuhan orang lain dan perhatian atas kehidupan mereka.

h. 9 Jenis Gaya Kepemimpinan dalam Organisasi

Pasti Anda pernah melihat seorang yang mampu mengakomodasi sebagian besar orang dengan berbagai latar belakang, budaya, kompetensi, ide, pendidikan untuk dapat bekerja sama demi menuju sebuah tujuan tertentu

a. Kepemimpinan Otokratis

Pemimpin sangat dominan dalam setiap pengambilan keputusan dan setiap kebijakan, peraturan, prosedur diambil dari idenya sendiri. Kepemimpinan jenis ini memusatkan kekuasaan pada dirinya sendiri. la membatasi inisiatif dan daya pikir dari para anggotanya. Pemimpin yang otoriter tidak akan memperhatikan kebutuhan dari bawahannya dan cenderung berkomunikasi satu arah yaitu dari atas (pemimpin) ke bawah (anggota). Jenis kepemimpinan ini biasanya dapat kita temukan di akademi kemiliteran dan kepolisian.

b. Kepemimpinan Birokrasi

Gaya kepemimpinan ini biasa diterapkan dalam sebuah perusahaan dan akan efektif apabila setiap karyawan mengikuti setiap alur prosedur dan melakukan tanggung jawab rutin setiap hari. Tetap saja dalam gaya kepemimpinan ini tidak 
ada ruang bagi para anggota untuk melakukan inovasi karena semuanya sudah diatur dalam sebuah tatanan prosedur yang harus dipatuhi oleh setiap lapisan.

c. Kepemimpinan Partisipatif

Dalam gaya kepemimpinan partisipatif, ide dapat mengalir dari bawah (anggota) karena posisi kontrol atas pemecahan suatu masalah dan pembuatan keputusan dipegang secara bergantian. Pemimpin memberikan ruang gerak bagi para bawahan untuk dapat berpartisipasi dalam pembuatan suatu keputusan serta adanya suasana persahabatan dan hubungan saling percaya antar pimpinan dan anggota.

d. Kepemimpinan Delegatif

Gaya kepemimpinan ini biasa disebut Laissez-faire dimana pemimpin memberikan kebebasan secara mutlak kepada para anggota untuk melakukan tujuan dan cara mereka masing-masing. Pemimpin cenderung membiarkan keputusan dibuat oleh siapa saja dalam kelompok sehingga terkadang membuat semangat kerja tim pada umumnya menjadi rendah. Jenis kepemimpinan ini akan sangat merugikan apabila para anggota belum cukup matang dalam melaksanakan tanggung jawabnya dan memiliki motivasi tinggi terhadap pekerjaan. Namun sebaliknya dapat menjadi boomerang bagi perusahaan bila memiliki karyawan yang bertolak belakang dari pernyataan sebelumnya. 
e. Kepemimpinan Transaksional

Kepemimpinan jenis ini cenderung terdapat aksi transaksi antara pemimpin dan bawahan dimana pemimpin akan memberikan reward ketika bawahan berhasil melaksanakan tugas yang telah diselesaikan sesuai kesepakatan. Pemimpin dan bawahan memiliki tujuan, kebutuhan dan kepentingan masing-masing.

f. Kepemimpinan Transformasional

Gaya kepemimpinan transformasional dapat menginspirasi perubahan positif pada mereka (anggota) yang mengikuti. Para pemimpin jenis ini memperhatikan dan terlibat langsung dalam proses termasuk dalam hal membantu para anggota kelompok untuk berhasil menyelesaikan tugas mereka. Pemimpin cenderung memiliki semangat yang positif untuk para bawahannya sehingga semangatnya tersebut dapat berpengaruh pada para anggotanya untuk lebih energik. Pemimpin akan sangat mempedulikan kesejahteraan dan kemajuan setiap anak buahnya.

g. Kepemimpinan Melayani (Servant)

Hubungan yang terjalin antara pemimpin yang melayani dengan para anggota berorientasi pada sifat melayani dengan standar moral spiritual. Pemimpin yang melayani lebih mengutamakan kebutuhan, kepentingan dan aspirasi dari para anggota daripada kepentingan pribadinya. 
h. Kepemimpinan Karismatik

Pemimpin yang karismatik memiliki pengaruh yang kuat atas para pengikut oleh karena karisma dan kepercayaan diri yang ditampilkan. Para pengikut cenderung mengikuti pemimpin karismatik karena kagum dan secara emosional percaya dan ingin berkontribusi bersama dengan pemimpin karismatik. Karisma tersebut timbul dari setiap kemampuan yang mempesona yang ia miliki terutama dalam meyakinkan setiap anggotanya untuk mengikuti setiap arahan yang ia inginkan.

i. Kepemimpinan Situasional

Pemimpin yang menerapkan jenis kepemimpinan situasional lebih sering menyesuaikan setiap gaya kepemimpinan yang ada dengan tahap perkembangan para anggota yakni sejauh mana kesiapan dari para anggota melaksanakan setiap tugas. Gaya kepemimpinan situasional mencoba mengkombinasikan proses kepemimpinan dengan situasi dan kondisi yang ada.

Setidaknya ada 4 gaya yang diterapkan oleh pemimpin jenis ini, diantaranya:

1. Telling-Directing (memberitahu, menunjukkan, memimpin, menetapkan),

2. Selling-Coaching (menjual, menjelaskan, memperjelas, membujuk),

3. Participating-Supporting (mengikutsertakan, memberi semangat, kerja sama),

4. Delegating (mendelegasi, pengamatan, mengawasi, penyelesaian). 


\section{BAB 2}

\section{Perilaku Individu dan Perilaku Kerja}

\section{A. Pengertian Perilaku Individu dan Perilaku Kerja}

1. Perilaku Individu

Pengertian Perilaku adalah tindakan atau aktivitas dari manusia itu sendiri yang mempunyai bentangan arti yang sangat luas antara lain : berjalan, berbicara, menangis, tertawa, bekerja, kuliah, menulis, membaca, dan sebagainya. Dari uraian tersebut bisa disimpulkan bahwa perilaku manusia adalah semua kegiatan atau aktivitas manusia, baik yang diamati langsung, maupun yang tidak dapat diamati oleh pihak luar (Notoatmodjo, 2003). Sedangkan dalam pengertian umum perilaku adalah segala perbuatan atau tindakan yang dilakukan oleh makhluk hidup. Pengertian perilaku dapat dibatasi sebagai keadaan jiwa untuk berpendapat, berfikir, bersikap, dan lain sebagainya yang merupakan refleksi dari berbagai macam aspek, baik fisik maupun non fisik.

Perilaku juga diartikan sebagai suatu reaksi psikis seseorang terhadap lingkungannya, reaksi yang dimaksud digolongkan menjadi dua, yakni :

a. bentuk pasif (tanpa tindakan nyata atau konkrit),

b. dalam bentuk aktif (dengan tindakan konkrit),

Tentunya banyak juga para ahli memiliki pandangan masing-masing tentang Pengertian perilaku ini, berikut daftar pengertian menurut para ahli di bidangnya: 
1. Menurut Ensiklopedi Amerika, perilaku diartikan sebagai suatu aksi dan reaksi organisme terhadap lingkungannya, hal ini berarti bahwa perilaku baru akan terwujud bila ada sesuatu yang diperlukan untuk menimbulkan tanggapan yang disebut rangsangan, dengan demikian maka suatu rangsangan tertentu akan menghasilkan perilaku tertentu pula. Robert Y. Kwick (1972)

2. menyatakan bahwa perilaku adalah tindakan atau perbuatan suatu organisme yang dapat diamati dan bahkan dipelajari.

3. Menurut Skinner, seperti yang dikutip oleh Notoatmodjo (2003), merumuskan bahwa perilaku merupakan respon atau reaksi seseorang terhadap stimulus atau rangsangan dari luar. Oleh karena perilaku ini terjadi melalui proses adanya stimulus terhadap organisme, dan kemudian organisme tersebut merespons, maka teori Skinner ini disebut teori "S-O-R" atau Stimulus - Organisme - Respon.

4. Menurut Heri Purwanto, perilaku adalah pandanganpandangan atau perasaan yang disertai kecendrungan untuk bertindak sesuai sikap objek tadi.

5. Menurut Petty Cocopio, perilaku adalah evaluasi umum yang dibuat manusia terhadap dirinya sendiri, obyek atau issue.

6. Menurut Chief, Bogardus, Lapierre, Mead Dan Gordon Allport, menurut kelompok pemikiran ini sikap merupakan semacam kesiapan untuk bereaksi terhadap suatu objek dengan cara-cara tertentu. Dapat dikatakan bahwa kesiapan yang dimaksudkan merupakan kecendrungan yang potensial untuk bereaksi dengan cara tertentu apabila 
individu dihadapkan pada suatu stimulus yang menghendaki adanya respon.

7. Menurut Louis Thurstone, Rensis Likert Dan Charles Osgood, menurut mereka perilaku adalah suatu bentuk evaluasi atau reaksi perasaan. Berarti sikap seseorang terhadap suatu objek adalah perasaan mendukung atau memihak (favorable) maupun perasaan tidak mendukung atau tidak memihak (unfavorable) pada objek tersebut.

8. Menurut Elton Mayo Studi Hawthorne di Western Electric Company, Chicago pada tahun 1927-1932 merupakan awal munculnya studi perilaku dalam organisasi Mayo seorang psikolog bersama Fritz Roetthlisberger dari Harvard University memandu penelitian tentang rancang ulang pekerjaan, perubahan panjang hari kerja dan waktu kerja dalam seminggu, pengenalan waktu istirahat, dan rencana upah individu dibandingkan dengan upah kelompok.

9. Menurut Reward Dan Reinforcement, menurut pendapat mereka tingkah laku seseorang senantiasa didasarkan pada kondisi, yaitu tindakan mengenal atau memikirkan seseorang terlibat langsung dalam situasi itu dan memperoleh insight untuk pemecahan masalah.

10. Menurut Chester Barnard, Barnard dalam karyanya The Functions of The Executive menekankan agar organisasi dan individu dapat berhasil, organisasi atau individu tersebut harus mengembangkan kerja sama. Barnard menekankan pentingnya pengakuan terhadap adanya organisasi formal, Barnard merupakan orang pertama yang memperlakukan organisasi sebagai suatu system. 
11. Menurut Parker Follet, keduanya memfokuskan studinya pada hubungan antara atasan dan bawahan, Follet meletakkan kelompok diatas individu. Melalui kelompok kemampuan individu dapat dimaksimalkan, organisasi ditentukan oleh kerjasama atasan dengan bawahan dengan meningkatkan partisipasi, komunikasi, kooordinasi, dan pembagian wewenang.

12. Menurut Frederick Herzberg, sama halnya seperti Maslow, Herzbeg dalam studinya juga mengembangkan konsepkonsep motivasi yang mana merupakan penentu utama munculnya motivasi yaitu kondisi tempat kerja, upah kualitas pengawasan dan pengakuan, promosi dan peningkatan profesionalisme.

\section{Perilaku Kerja}

1. Definisi

Perilaku kerja merupakan tindakan dan sikap yang ditunjukkan oleh orang-orang yang bekerja. Pengertian perilaku kerja menurut para ahli sebagai berikut:

1. Perilaku Kerja menurut Bond and Meyer (1987 : 40 )

Perilaku kerja yaitu kemampuan kerja dan perilaku-perilaku dimana hal tersebut sangat penting di setiap pekerjaan dan situasi kerja.

2. Perilaku Kerja menurut Robbins (2002:35 dan 39)

Perilaku kerja yaitu dimana orang-orang dalam lingkungan kerja dapat mengaktualisasikan dirinya 
melalui sikap dalam bekerja. (Robbins menekankan pada sikap yang diambil oleh pekerja untuk menentukan apa yang akan mereka lakukan di lingungan tempat kerja mereka).

3. Definisi yang lain menyebutkan bahwa perilaku kerja merupakan kemampuan kerja dan perilaku-perilaku darai para pekerja dimana mereka menunjukkan tindakan dalam melaksanakan tugas-tugas yang ada di tempat mereka bekerja.

2. Pentingnya Perilaku Kerja

Kerberhasilan di berbagai wilayah kehidupan ternyata ditentukan oleh perilaku manusia, terutama perilaku kerja. Sebagian orang menyebut perilaku kerja ini sebagai motivasi, kebiasaan (habit) dan budaya kerja. Oleh karena itu diupayakan untuk membentuk perilaku kerja yang konsisten dan positif. Menurut Sinamo (2002), ada delapan paradigma di tingkat perilaku kerja yang sanggup menjadi basis keberasilan baik di tingkat pribadi, organisasional maupun sosial, yaitu :
a. Bekerja Tulus,
b. Bekerja Tuntas,
c. Bekerja Benar,
d. Bekerja Keras,
e. Bekerja Serius,
f. Bekerja Kreatif,
g. Bekerja Unggul,
h. Bekerja Sempurna. 
3. Perilaku kerja menurut gender Menurut Gray (2002: 401), mengemukakan

bahwa antara pria dan wanita harus mengetahui bahwa perbedaan gender bisa mempengaruhi perilaku kerja mereka. Tanpa disadari oleh kaum pria dan wanita, banyak ucapan atau perilaku yang dianggap wajar oleh masingmasing gender dapat menyinggung perasaan dan harga diri lawan jenis. Hal ini tentu saja dapat mengakibatkan konflik yang ujung-ujungnya juga dapat mempengaruhi perilaku kerja serta mengganggu suasana kerja yang nyaman. Gray (2002: 403) untuk menciptakan perilaku kerja yang baik harus

memperhatikan:

1. Komunikasi pria dan wanita,

2. Perasaan di tempat bekerja,

3. Menetapkan batasan dalam tiap perilaku kerja,

4. Mengingatkan berbagai perbedaan yang ada

Kesimpulan:

Perilaku kerja antara pria dan wanita tidak sama. Dalam memahami perilaku kerja menurut gender dibutuhkan komunikasi dan pemahaman yang penuh, sehingga tidak mengakibatkan konflik dalam bekerj a.

4. Indikator Perilaku Kerja

1. Indikator menurut kamus Oxford (2000: 690) Indikator menurut kamus Oxford is a sign that shows you what something is like or how situation is changing. Yang artinya yaitu suatu petunjuk atau tanda yang menunjukkan 
bagaimanakah dengan suatu keadaan atau bagaimana suatu situasi berubah-ubah. Di dalam perilaku kerja juga terdapat indikatornya, dimana indikator tersebut juga merupakan hal-hal yang dapat mengukur sampai sejauh mana perilaku kerja dapat berperan di tempat kerja.

2. Indikator perilaku kerja menurut Anthony \& Jansen (1984: 41) Menurut Anthony \& Jansen ada indikator yang benar-benar mempengaruhi perilaku kerja,yaitu:

a. Getting along (keramahtamahan) Menurut kamus idiomatic NTC's (1993:291) yaitu (for people or other creatures) to be amiable with one another. Yang artinya ramah terhadap satu dengan yang lainnya. Contohnya yaitu seperti hubungan dengan antar para pekerja dan atasan. Hal ini berarti bahwa suatu hubungan yang ramah dapat mempengaruhi perilaku kerja antar pekerja dan atasan. (Harry W.C. Michon, Hans Kroon, Jaap Weeghel \& Aart H. Schene: 42).

b. Doing the job(melakukan pekerjaan, contoh : kualitas

pekerjaan)

Melakukan suatu pekerjaan harus dilakukan dengan baik agar dapat mengukur suatu kualitas pekerjaan yang sesuai dengan bidangnya. Harry W.C. Michon, Hans Kroon, Jaap Weeghel \& Aart H. Schene : 42).

c. Being dependable (dapat diandalkan, dalam hal ini contohnya ketepatan waktu) Menurut Oxford Dictionary "being dependable" is that can be relied on to do what you want or need. Yang artinya seorang pekerja harus bisa diandalkan. 
Contohnya seperti ketepatan waktu untuk mask kerja atau menghadiri rapat (Harry W.C. Michon, Hans Kroon, Jaap Weeghel \& Aart H. Schene :42).

3. Indikator kerja menurut Griffiths, Empat indikator kerja menurut Griffiths (1973:41 dan 42), yaitu :

a. Social relationships-response to supervision Seorang pekerja harus memiliki hubungan sosial yang baik dengan pekerja yang lain, dimana masingmasing pekerja harus mengawasi rekan kerja agar bertindak di jalan yang benar dan mengingatkan apabila ada kesalahan. (Harry W.C. Michon, Hans Kroon, Jaap Weeghel \& Aart H. Schene :42).

b. Task competence (kemampuan untuk melakukan pekerjaan)

Ada tanggung jawab dan kesadaran dari para pekerja dalam melaksanakan seluruh tugasnya karena mereka memiliki kemampuan untuk melakukan hal tersebut (Harry W.C. Michon, Hans Kroon, Jaap Weeghel \& Aart H. Schene :42).

c. Work motivation (motivasi kerja)

Adanya kemauan untuk bekerja untuk mencapai suatu tujuan tertentu (Harry W.C. Michon, Hans Kroon, Jaap Weeghel \& Aart H. Schene :42).

d. Initiative-confidence (inisiatif-percaya diri)

Menurut kamus Oxford $(2000,699)$ initiative is the ability to decide and act on your won without waiting for somebody to tell your what to do. Sedangkan menurut kamus Oxford (2000, 272) confidence is a belief in your own ability to do things 
and be succesfull. Keduanya dapat diartikan yaaitu dalam perilaku kerja yang baik harus memupuk rasa percaya diri yang penuh serta mengambil inisiatif bahwa semua pekerjaan dapat dilaksanakan sesuai dengan jobdesc yang ada.

4.Indikator perilaku kerja menurut Bryson et al (1997: 41 dan 42)

Empat indikator yang mempengaruhi perilaku kerja menurut Bryson et al, yaitu:

a. Cooperatives-social skills (kemampuan berhubungan sosial)

Menurut Oxford $(2000,270)$ cooperativeness is involving doing something together or working together with others towards a shared aim. Yang memiliki arti yaitu mengandalkan kemampuan sosial untuk bekerjasama dengan antar para pekerja untuk mencapai suatu tujuan bersama.

b. Work quality (kualitas pekerjaan)

Para pekerja harus menunjukkan kualitas kerja yang baik agar dapat diakuai dan dihargai (Harry W.C. Michon, Hans Kroon, Jaap Weeghel \& Aart H. Schene :42).

c. Work habits (kebiasaan kerja) Kebiasaan kerja dihubungkan dengan perilaku yang positif dan negatif di tempat kerja (Harry W.C. Michon, Hans Kroon, Jaap Weeghel \& Aart H. Schene :42). 
d. Personal presentation (pengendalian diri, contoh : tidak menjadi mudah marah dan agresif dan tidak berperilaku

Di tempat kerja harus dapat mengendalikan diri dan menunjukkan pribadi yang profesional dalam bekerja (Harry W.C. Michon, Hans Kroon, Jaap Weeghel \& Aart H. Schene :42).

5. Indikator perilaku kerja menurut Tsang \& Chiu (2000: 41 dan 42)

Tiga indikator penting yang mempengaruhi perilaku kerja, yaitu

a. Social behavior (hubungan sosial)

Dapat menunjukkan perilaku sosial yang sesuai dengan aturan dan norma yang ada di tempat kerja (Harry W.C. Michon, Hans Kroon, Jaap Weeghel \& Aart H. Schene :42).

b. Vocational skill (keahlian atau jemampuan berdasarkan kejuruan)

Menurut Oxford (2000: 1506) vocational skills is connected with the skills, knowledge. That you need to have in order to do a particular job. Yang artinya hal tersebut berhubungan dengan kemampuan atau pengetahuan. Dan hal tersebut dibutuhkan untuk melaksanakan sebuah pekerjaan.

Contohnya yaitu kemampuan kejuruan memasak dibutuhkan oleh seorang koko sehingga keahlian memasaknya yang sesuai dengan kejuruan yang diambil 
diperlukan di tempat ia bekerja.

c. General behavior (perilaku umum)

Perilaku umum yang ditunjukkan akan dapat diketahui untuk mendeteksi perilaku kerja para karyawan (Harry W.C. Michon, Hans Kroon, Jaap Weeghel \& Aart H. Schene :42).

5. Faktor-faktor perilaku kerja

Faktor-faktor yang dapat mempengaruhi perilaku kerja di tempat kerja, yaitu :

a. Lingkungan kerja

Di dalam suatu lingkungan kerja harus benar-benar memberikan rasa aman bagi para pekerja. Para pekerja atau karyawan menaruh perhatian yang besar terhadap lingkungan kerja, baik dari strategi kenyamanan pribadi maupun kemudahan untuk melakukan pekerjaan dengan baik. Lingkungan fisik yang aman, nyaman, bersih dan memiliki tingkat gangguan minimum sangat disukai oleh para pekerja (Robbins, 2002:36).

b. Konflik

Konflik dapat konstruktif atau destruktif terhadap fungsi dari suatu kelompok atau unit. Tapi sebagian besar konflik cenderung merusak perilaku kerja yang 
baik karena konflik akan menghambat pencapaian tujuan dari suatu pekerjaan (Robbins, 2002: 199).

c. Komunikasi

Dapat memahami perilaku kerja, komunikasi merupakan salah satu faktor terpenting yang berperan sebagai penyampaian dan pemahaman dari sebuah arti (Robbins, 2002: 146).

6. Bentuk-bentuk Perubahan Perilaku Individu

a. Perubahan Alamiah (Natural Change)

Perilaku manusia selalu berubah. Sebagian perubahan itu disebabkan karena kejadian alamiah. Contoh : perubahan perilaku yang disebabkan karena usia seseorang.

b. Perubahan terencana (Planned Change)

Perubahan perilaku ini terjadi karena memang direncanakan sendiri oleh subjek.contoh : perubahan perilaku seseorang karena tujuan tertentu atau ingin mendapatkan sesuatu yang bernilai baginya.

c. Kesediaan untuk berubah ( Readdiness to Change )

Apabila terjadi suatu inovasi atau program-program pembangunan di dalam organisasi, maka yang sering terjadi adalah sebagian orang sangat cepat untuk menerima inovasi atau perubahan tersebut, dan ada sebagian orang lagi sangat lambat untuk menerima inovasi atau perubahan tersebut. Contoh : perubahan teknologi pada suatu lembaga organisasi, misal dari mesin ketik manual ke mesin komputer, biasanya orang yang usianya tua sulit untuk menerima perubahan pemakaian teknologi tersebut. 


\section{B. Cara Mengelola Perilaku Individu}

1. Strategi Perubahan Perilaku Individu

Beberapa strategi untuk memperoleh perubahan perilaku, dikelompokkan menjadi tiga :

a. Menggunakan kekuatan/kekuasaan atau dorongan Misal : dengan adanya peraturan-peraturan / perundang-undangan yang harus dipatuhi oleh anggota masyarakat.

b. Strategi ini dapat berlangsung cepat akan tetapi belum tentu berlangsung lama karena perubahan perilaku terjadi tidak atau belum didasari oleh kesadaran sendiri.

c. Pemberian informasi

Dengan memberikan informasi-informasi tentang sesuatu hal yang berkaitan dengan hal tertentu.

d. Diskusi partisipasi

Cara ini adalah sebagai peningkatan cara yang kedua di atas yang dalam memberikan informasi-informasi tentang peraturan baru organisasi tidak bersifat searah saja tetapi dua arah.

2. Teori Tentang Perubahan Perilaku Individu

\section{Teori Kurt Lewin}

Kurt Lewin (1970) berpendapat bahwa perilaku manusia adalah suatu keadaan yang seimbang antara 
kekuatan-kekuatan pendorong (driving forces) dan kekuatan-kekuatan penahan (restrining forces). Perilaku ini dapat berubah apabila terjadi ketidakseimbangan antara kedua

kekuatan tersebut didalam diri seseorang.

Sehingga ada 3 kemungkinan terjadinya perubahan perilaku pada diri seseorang itu, yakni:

2. Kekuatan-kekuatan pendorong meningkat. Hal ini terjadi karena adanya stimulus-stimulus yang mendorong untuk terjadinya perubahanperubahan perilaku. Stimulus ini berupa informasi-informasi sehubungan dengan perilaku yang bersangkutan.

3. Kekuatan-kekuatan penahan menurun. Hal ini akan terjadi karena adanya stimulus-stimulus yang memperlemah kekuatan penahan tersebut.

4. Kekuatan pendorong meningkat, kekuatan penahan menurun. Dengan keadaan semacam ini jelas juga akan terjadi perubahan perilaku.

\section{Teori Stimulus-Organisme-Respons (SOR)}

Teori ini mendasarkan asumsi bahwa penyebab terjadinya perubahan perilaku tergantung kepada kualitas rangsang (stimulus) yang berkomunikasi dengan organisme. Artinya kualitas dari sumber komunikasi (sources) misalnya kredibilitas, kepemimpinan, gaya berbicara sangat menentukan keberhasilan perubahan perilaku seseorang, kelompok atau masyarakat. Hosland, et al (1953) mengatakan bahwa proses perubahan perilaku pada hakekatnya sama dengan proses belajar. Proses perubahan perilaku tersebut 
menggambarkan proses belajar pada individu yang terdiri dari :

a. Stimulus (rangsang) yang diberikan pada organisme dapat diterima atau ditolak. Apabila stimulus tersebut tidak diterima atau ditolak berarti stimulus itu tidak efektif mempengaruhi perhatian individu dan berhenti disini. Tetapi bila stimulus diterima oleh organisme berarti ada perhatian dari individu dan stimulus tersebut efektif.

b. Apabila stimulus telah mendapat perhatian dari organisme (diterima) maka ia mengerti stimulus ini dan dilanjutkan kepada proses berikutnya. Setelah itu organisme mengolah stimulus tersebut sehingga terjadi kesediaan untuk bertindak demi stimulus yang telah diterimanya (bersikap).

d. Akhirnya dengan dukungan fasilitas serta dorongan dari lingkungan maka stimulus tersebut mempunyai efek tindakan dari individu tersebut (perubahan perilaku).

\section{Teori Fungsi}

Teori ini berdasarkan anggapan bahwa perubahan perilaku individu itu tergantung kepada kebutuhan. Hal ini berarti bahwa stimulus yang dapat mengakibatkan perubahan perilaku seseorang apabila stimulus tersebut dapat dimengerti dalam konteks kebutuhan orang tersebut. Menurut Katz (1960) perilaku dilatarbelakangi oleh kebutuhan individu yang bersangkutan. Katz berasumsi bahwa : 
a. Perilaku itu memiliki fungsi instrumental, artinya dapat berfungsi dan memberikan pelayanan terhadap kebutuhan. Seseorang dapat bertindak (berperilaku) positif terhadap objek demi pemenuhan kebutuhannya. Sebaliknya bila objek tidak dapat memenuhi memenuhi kebutuhannya maka ia akan berperilaku negatif.

b. Perilaku dapat berfungsi sebagai defence mecanism atau sebagai pertahanan diri dalam menghadapi lingkungannya. Artinya dengan perilakunya, dengan tindakan-tindakannya, manusia dapat melindungi ancaman-ancaman yang datang dari luar.

c. Perilaku berfungsi sebagai penerima objek dan memberikan arti. Dalam peranannya dengan tindakannya itu, seseorang senantiasa menyesuaikan diri dengan lingkungannya. Dengan tindakan seharihari tersebut seseorang telah melakukan keputusankeputusan sehubungan dengan objek atau stimulus yang dihadapi. Pengambilan keputusan yang mengakibatkan tindakan-tindakan tersebut dilakukan secara spontan dan dalam waktu yang singkat.

d. Perilaku berfungsi sebagai nilai ekspresif dari diri seseorang dalam menjawab suatu situasi. Nilai ekspresif ini berasal dari konsep diri seseorang dan merupakan pencerminan dari hati sanubari. Oleh sebab itu perilaku itu dapat merupakan "layar" dimana segala ungkapan diri orang dapat dilihat. Misalnya orang yang sedang marah, senang, gusar, dan sebagainya dapat dilihat dari perilaku atau tindakannya. 
Teori ini berkeyakinan bahwa perilaku itu mempunyai fungsi untuk menghadapi dunia luar individu dan senantiasa menyesuaikan diri dengan lingkungannya menurut kebutuhannya. Oleh sebab itu didalam kehidupan manusia, perilaku itu tampak terus-menerus dan berubah secara relatif.

\section{Moh Surya (1997) mengemukakan ciri-ciri dari perubahan perilaku, yaitu :}

a. Perubahan yang disadari dan disengaja (intensional).

b. Perubahan perilaku yang terjadi merupakan usaha sadar dan disengaja dari individu yang bersangkutan. Begitu juga dengan hasil-hasilnya, individu yang bersangkutan menyadari bahwa dalam dirinya telah terjadi perubahan, misalnya pengetahuannya semakin bertambah atau keterampilannya semakin meningkat, dibandingkan sebelum dia mengikuti suatu proses belajar. Misalnya, seorang manajer sedang belajar tentang strategi bisnis. Dia menyadari bahwa dia sedang berusaha mempelajari tentang Strategi bisnis. Begitu juga, setelah belajar Strategi bisnis dia menyadari bahwa dalam dirinya telah terjadi perubahan perilaku, dengan memperoleh sejumlah pengetahuan, sikap dan keterampilan yang berhubungan dengan Strategi bisnis.1.Perubahan yang berkesinambungan (kontinyu).

c. Bertambahnya pengetahuan atau keterampilan yang dimiliki pada dasarnya merupakan kelanjutan dari pengetahuan dan keterampilan yang telah diperoleh sebelumnya. Begitu juga, pengetahuan, sikap dan keterampilan yang telah diperoleh itu, akan menjadi dasar 
bagi pengembangan pengetahuan, sikap dan keterampilan berikutnya.

d. Perubahan yang fungsional.Setiap perubahan perilaku yang terjadi dapat dimanfaatkan untuk kepentingan hidup individu yang bersangkutan, baik untuk kepentingan masa sekarang maupun masa mendatang.

e. Perubahan yang bersifat positif.

Perubahan perilaku yang terjadi bersifat normatif dan menujukkan ke arah kemajuan.

f. Perubahan yang bersifat aktif.

Untuk memperoleh perilaku baru, individu yang bersangkutan aktif berupaya melakukan perubahan. Misalnya, manajer ingin memperoleh pengetahuan baru tentang strategi bisnis, maka manajer tersebut aktif melakukan kegiatan membaca dan mengkaji buku-buku strategi bisnis, berdiskusi dengan manajer lain tentang strategi bisnis dan sebagainya.

g. Perubahan yang bersifat pemanen.

Perubahan perilaku yang diperoleh dari proses belajar cenderung menetap dan menjadi bagian yang melekat dalam dirinya. Misalnya, manajer belajar mengoperasikan program akuntansi, maka penguasaan keterampilan mengoperasikan komputer program akuntansi tersebut akan menetap dan melekat dalam diri mahasiswa tersebut.

h. Perubahan yang bertujuan dan terarah.

Individu melakukan kegiatan belajar pasti ada tujuan yang ingin dicapai, baik tujuan jangka pendek, jangka menengah maupun jangka panjang. Misal seorang manajer mewmpelajari strategi bisnis mempunyai tujuan jangka pendeknya untuk tahu tentang apa-apa yang akan 
dilakukan dalam dunia bisnis, sedangkan tujuan jangka panjangnya adalah untuk ahli dalam bisnis dan mungkin untuk opromosi ke jabatan yang lebih tinggi karena telah menguasai bidang tertentu.

i. Perubahan perilaku secara keseluruhan.

Perubahan perilaku belajar bukan hanya sekedar memperoleh pengetahuan semata, tetapi termasuk memperoleh pula perubahan dalam sikap dan keterampilannya.

3. Cara-cara Perubahan Perilaku Individu

a. Dengan Paksaaan. Ini bisa dengan : Mengeluarkan instruksi atau peraturan, dan ancaman huluman kalau tidak mentaati instruksi atau peraturan tersebut.

b. Dengan memberi imbalan : Imbalan bisa berupa materi seperti uang atau barang, tetapi blsa juga imbalan yang tidak berupa materi, seperti pujian, dan sebagainya.

c. Dengan membina hubungan baik : Kalau kita mempunyai hubungan yang baik dengan seseorang atau dalam organisasi. biasanya orang tersebut akan mengikuti anjuran kita untuk berbuat sesuatu.

d. Dengan menanamkan kesadaran dan motivasi pada individu sehingga individu akan berubah dengan kesadaran dirinya.

e. Dengan menunjukkan contoh-contoh pada individu dalam organisasi untuk melakukan tindakan tertentu yang diinginkan organisasi. 
4. Cara Memprakarsai Perubahan

Perubahan budaya organisasi sangat dimungkinkan mengingat budaya organisasi merupakan variabel yang dinamis, di sisi lan organisasi sebagai living organism selalu mengalami perubahan dan perkembangan. Kecocokan antara budaya organisasi dengan lingkungan eksternal juga merupakan salah satu pertimbangan perlu tidaknya perubahan budaya organisasi.

Merubah budaya bukanlah sesuatu hal yang mudah karena sekali budaya tersebut terkristalisasi ke dalam masing-masing anggota organisasi, maka anggota organisasi cenderung mempertahankannya tanpa memperhatikan bahwa budaya tersebut functional atau disfunctional terhadap kehidupan organisasi. Perubahan budaya bisa memakan waktu sampai 10 tahun.

John kotler, seorang pakar kepemimpinan dan manajemen perubahan, percaya bahwa perubahan organisasi khususnya akan gagal karena manajemen senior melakukan satu atau lebih kesalahan berikut ini :

a. Kegagalan untuk menetapkan suatu rasa kegentingan mengenai kebutuhan akan perubahan seperti mencairkan organisasi dengan menciptakan alasan yang memaksa mengapa perubahan diperlukan.

b. Kegagalan untuk menetapkan suatu koalisi yang cukup kuat untuk memberikan pedoman yang bertanggungjawab untuk memimpin dan mengelola perubahan. Deskripsinya seperti menciptakan orang- 
orang yang lintas fungsi dan lintas kelompok dengan kekuatan yang mencukupi untuk memimpin kelompok.

c. Kegagalan untuk menetapkan suatu visi yang memandu proses perubahan.

d. Kegagalan untuk mengkomunikasikan visi baru secara efektif.

e. Kegagalan untuk menghilangkan halangan yang merintangi pencapaian visi baru.

f. Kegagalan untuk secara sistematis merencanakan dan menciptakan kemenangan jangka pendek. Kemenangan jangka pendek mencerminkan pencapaian dari hasil atau tujuan penting.

g. Terlalu cepat mengumumkan kemenangan. Hal ini dapat menggelincirkan perubahan jangka panjang pada infrastruktur yang sering diperlukan untuk mencapai suatu visi.

h. Kegagalan untuk menjangkarkan perubahan pada budaya organisasi. Hal ini diperlukan waktu bertahun tahun untuk tertanam dalam budaya organisasi.

kotler merekomendasikan bahwa organisasi sebaiknya mengikuti delapan langkah yang saling berurutan untuk mengatasi masalah -masalah yang berasal dari tekanan kekuatan internal maupun kekuatan eksternal.

5. Tahap-tahap proses perubahan Proses perubahan meliputi enam tahapan :

a. Tekanan dan desakan. Proses mulai ketika manajemen puncak mulai merasa adanya kebutuhan atau tekanan akan perubahan, biasanya disebabkan berbagai masalah 
yang berarti, seperti penurunan pejualan atau penurunan laba secara tajam.

b. Intervensi dan reorientasi. Konsultan atau pengantar perubahan dari luar sering digunakan untuk merumuskan masalah dan memulai proses dengan membuat para organisasi untuk memusatkan perhatiannya pada masalah tersebut.

c. Diagnosa dan pengenalan masalah. Informasi dikumpulkan dan dianalisa oleh pengantar perubahan dan manajemen.

d. Penemuan dan komitmen pada penyelesaian. Pengantar perubahan hendaknya merangsang pemikiran dan mencoba untuk menghindari penggunaan metodemetode lama yang sama. Penyelesaian-penyelesaian diketemukan melalui pengembangan secara kreatif, alternatif - alternatif baru dan masuk akal.

e. Percobaan dan pencarian hasil-hasil. Penyelesaianpenyelesaian pada tahap empat biasanya diuji dalam program-program percobaan berkala dan hasil-hasilnya dianalisis.

f. Penguatan dan penerimaan. Bila serangkaian kekuatan telah diuji dan sesuai keinginan, harus diterima secara sukarela. Pelaksanaan kegiatan yang telah diterima harus menjadi sumber penguatan dan menimbulkan keterikatan terhadap perubahan

\section{Rancangan Pekerjaan dan Pekerjaan}

\section{Rancangan Perkerjaan}

Diantara banyak faktor yang akan mempengaruhi rancangan perkerjaan adalah 
a. nilai-nilai pesialisasi yang sudah terbukti dan operasi yang berulang-ulang,

b. perubahan teknologi,

c. kebijakan-kebijakan serikat buruh,

d. kemapuan karyawan yang ada sekarang,

e. persediaan calon karyawan yang ada,

f. persyaratan interaksi antar perkerjaan didalam system itu,

g. kebutuhan-kebutuhan psikologi dan social manusia yang dapat dipenuhi oleh perkerja.

Satu dari masalah hubungan antar manusia yang paling biasa dikutip dalam rancangan perkerjaan ini adalah ketidakpuasan karyawan dalam perkerjaan yang berulang-ulang, tidak variasi, tidak berarti, rutin.

\section{Perluasan Perkerjaan}

Pemerkayaan perkerjaan adalah pendekatan terhadap rancangan perkerjaan yang paling disarankan oleh para ahli perilaku dan akan dibicarakan dalam bagian berikut. Keanekaragaman dapat dihasilkan dengan menambah fungsi, sehingga mungkin mengurangi kemonotonan.

\section{Pemerkayaan Perkerjaan}

Para ahli perilaku berpendapat bahwa karyawan akan menjadi " bersemangat" terhadap perkerjaannya jika (1) perkerjaannya bermakna, (2) pekerja mengetahui perkerjaannya, (3) perkerja bertanggung jawab secara pribadi atas hasil kerjanya. Dalam penerapan teori ke praktek, orang menyanyakan 
tentang bagaiman lima dimensi inti perkerjaan dapat dirancang ke dalam suatu unit kerja.

Banyak orang merasa bahwa dimensi yang paling kritis adalah otonomi perkerjaan. Tentu saja hal itu adalah perbedaan kritis antara perluasan perkerjaan dan pemerkayaan perkerjaan. Otonomi diciptaka melalui suatu proses "pemuatan vertical" yaitu, perkerja diberikan hak-hak untuk mengelola sendiri banyak bidang.

\section{Pekerjaan}

Pekerjaan merupakan suatu kegiatan yang wajib dilakukan oleh setiap orang demi kelangsungan hidupnya atau untuk memenuhi berbagai macam kebutuhan hidupnya. Setiap orang malakukan pekerjaan salah satunya untuk memenuhi kebutuhan pokoknya, karena kebutuhan pokok merupakan kebutuhan yang harus dipenuhi dan tidak bisa di tunda-tunda. Kebutuhan tersebut misalnya pokok seperti makan, minum, pakaian, pendidikan dan lain-lain. Untuk mendapat memenuhi berbagai kebutuhannya makan manusia membutuhkan uang, dan umumnya uang di dapatkan dari bekerja, saat ini banyak sekali pekerjaan yang dilakukan manusia untuk menghasilkan uang.

Jadi yang dimaksud pekerjaan adalah aktivitas utama yang dilakukan manusia untuk memenuhi kebutuhan hidupnya. Dalam arti yang sempit pekerjaan yaitu suatu aktivitas yang dapat menghasilkan uang. Sedangkan dalam segi ekonomi pekerjaan yaitu semua aktivitas yang dilakukan manusia, baik itu dilakukan 
secara individu ataupun secara organisasi, baik secara tertutup ataupun secara terbuka kemudian dari pekerjaan tersebut dapat menghasilkan suatu produk atau jasa sehingga dapat mendapatkan uang dan dijadikan sebagai mata pencarian.

\section{Hal-hal Yang Dibutuhkan Dalam Pekerjaan}

Beberapa kemampuan yang di butuhkan untuk mendapatkan keberhasilan dalam bekerja, diantaranya seperti:

a. Skill

Skill adalah kemahiran yang di miliki setiap orang, skill umumnya bisa di peroleh melalui pelatihan dan pendidikan. Contoh keterampilan atau skill misalnya seseorang yang mampu menoprasikan komputer atau mesin produksi, seseorang yang mampu membuat program komputer dan memperbaiki komputer jika terjadi masalah atau bahkan memiliki kemampuan untuk memperbaiki mesin produksi jika terjadi masalah pada mesin tersebut.

b. Pengetahuan

Dapat di katakan pengetahuan merupakan pondasi dasar yang harus di miliki dalam bekerja, karena pengetahuan dapat membangun skill seseorang dalam bekerja dan tentunya pengetahuan juga dapat membantu menyelesaikan masalah yang sedang di hadapi.

c. Dapat bekerjasama 
Bisa bekerjasama dengan orang lain merupakan kemampuan yang dibutuhkan dalam bekerja, karena ada beberapa pekerjaan yang tidak dapat di selesaikan sendiri, jadi untuk menyelesaikan pekerjaan tersebut harus dilakukan dengan bekerja sama. Kemampuan bekerjasama juga harus di iringi dengan kemampuan berkomunikasi yang baik dan dapat menghargai pendapat orang lain dalam suatu tim. Karena dengan bekerjasama umumnya pekerjaan dapat di selesaikan dengan mudah dan lebih cepat.

d. Memiliki sikap jujur

Kejujuran sangat penting dalam bekerja, kenapa? karena dengan kejujuran kita dapat dipercayai oleh banyak orang dan tentunya orang yang jujur sangat di butuhkan oleh setiap perusahaan serta lebih di hormati dalam bekerja.

e. Sikap sopan santun

Sopan santun sangat perlu juga untuk mendapatkan keberhasilan kerja, karena dengan sikap ini seseorang akan selalu di hargai dalam bekerja.

f. Sikap pantang menyerah dan berdaya juang Sikap pantang menyerah atau sikap yang memiliki daya juang tinggi merupakan salah satu sikap yang perlu dimiliki dalam bekerja, karena sikap ini sangat penting sekali untuk mencapai keberhasilan kerja. Selalu ada permasalahan tidak hanya dapat di selesaikan dengan skill dan pengetahuan saja, tapi dalam menyelesaikan masalah harus di dukung juga dengan sikap pantang menyerah dan berdaya juang tinggi. 


\section{BAB 3}

\section{Persepsi, Atribut dan Emosi}

A. Konsep Pengertian, Persepsi Pengaruh Buruk, Stereotif Dan Distorsi

\section{Persepsi}

Persepsi adalah proses yang digunakan individu untuk mengelola dan menafsirkan kesan indera mereka dalam rangka memberikan makna kepada lingkungan mereka. Meski demikian, apa yang dipersepsikan seseorang dapat berbeda dari kenyataan obyektif. Tidak selalu berbeda, namun sering terdapat ketidaksepakatan.

Persepsi memiliki banyak sekali pengertian. Secara sederhana persepsi mengandung arti cara seseorang dalam memahami sesuatu atau bagaimana ia melihat suatu objek. Persepsi juga berarti proses pemahaman atau pemberian makna atas suatu informasi terhadap stimulus. Stimulus didapat dari proses penginderaan terhadaop objek, peristiwa, atau hubungan-hubungan antar gejala yang selanjutnya diproses oleh otak. Lewat persepsi lah, proses kognisi dimulai. 
Pengetian pesepsi menurut para ahli :

1. Bimo Walgito menyatakan bahwa persepsi merupakan proses yang terjadi di dalam diri individu yang dimulai dengan diterimanya rangsang, sampai rangsang itu disadari dan dimengerti oleh individu sehingga individu dapat mengenali dirinya sendiri dan keadaan di sekitarnya.

2. Davidoff berpendapat bahwa persepsi merupakan proses pengorganisasian dan penginterpretasian terhadap stimulus oleh organisme atau individu sehingga didapat sesuatu yang berarti dan merupakan aktivitas yang terintegrasi dalam diri individu.

3. Bower memberikan definisi yang hampir sama dengan kedua tokoh di atas bahwa persepsi adalah interpretasi tentang apa yang diinderakan atau dirasakan individu.

Persepsi dalam arti sempit : adalah penglihatan, bagaimana cara seseorang melihat sesuatu. Dalam arti luas : adalah pandangan atau pengertian , yaitu bagaimana seeseorang memandang atau mengartikan sesuatu.

Persepsi adalah suatu proses penggunaan pengetahuan yang telah dimiliki (yang disimpan didalam ingatan) untuk mendeteksi atau memperoleh dan 
menginterprestasi stimulus (rangsangan) yang diteriman oleh alat indera seperti mata, telinga, dan hidung (Matlin, 1989; Solso,1988). Secara singkat dapat dikatakan bahwa prsepsi merupakan suatu proses menginterprestasi atau menafsirkan informasi yang diperoleh melalui sistem indera manusia. Misalnya pada waktu seorang melihat sebuah gambar, membaca tulisan, atau mendengar suara tertentu, ia akan melakukan interprestasi berdasarkan pengetahuan yang dimilikinya dan relevan dengan hal-hal itu. Presepsi mencakup dua proses yaitu bottom-up atau data driven processing (aspek stimulus), dan top-down atau conceptually driven processing (aspek pengetahuan seseorang). Hasil persepsi seseorang mengenai sesuatu objek disamping dipengaruhi oleh penampilan objek itu sendiri, juga pengetahuan seseorang mengenai objek itu. Ada tiga aspek dalam presepsi yang dianggap sangat relevan dengan kognisi manusia, yaitu pencatatan indera, pengenalan pola, dan perhatian.

2. Faktor-faktor yang mempengaruhi persepsi

Faktor-faktor yang mempengaruhi persepsi pada dasarnya dibagi menjadi 2 yaitu Faktor Internal dan Faktor Eksternal.

a. Faktor Internal yang mempengaruhi persepsi, yaitu faktor-faktor yang 
terdapat dalam diri individu, yang mencakup beberapa hal antara lain :

1. Fisiologis. Informasi masuk melalui alat indera, selanjutnya informasi yang diperoleh ini akan mempengaruhi dan melengkapi usaha untuk memberikan arti terhadap lingkungan sekitarnya. Kapasitas indera untuk mempersepsi pada tiap orang berbeda-beda sehingga interpretasi terhadap lingkungan juga dapat berbeda.

2. Perhatian. Individu memerlukan sejumlah energi yang dikeluarkan untuk memperhatikan atau memfokuskan pada bentuk fisik dan fasilitas mental yang ada pada suatu obyek. Energi tiap orang berbedabeda sehingga perhatian seseorang terhadap obyek juga berbeda dan hal ini akan mempengaruhi persepsi terhadap suatu obyek.

3. Minat. Persepsi terhadap suatu obyek bervariasi tergantung pada seberapa banyak energi atau perceptual vigilance yang digerakkan untuk mempersepsi. Perceptual vigilance merupakan kecenderungan seseorang untuk memperhatikan tipe tertentu dari stimulus atau dapat dikatakan sebagai minat. 
4. Kebutuhan yang searah. Faktor ini dapat dilihat dari bagaimana kuatnya seseorang individu mencari obyekobyek atau pesan yang dapat memberikan jawaban sesuai dengan dirinya.

5. Pengalaman dan ingatan. Pengalaman dapat dikatakan tergantung pada ingatan dalam arti sejauh mana seseorang dapat mengingat kejadian-kejadian lampau untuk mengetahui suatu rangsang dalam pengertian luas.

6. Suasana hati. Keadaan emosi mempengaruhi perilaku seseorang, mood ini menunjukkan bagaimana perasaan seseorang pada waktu yang dapat mempengaruhi bagaimana seseorang dalam menerima, bereaksi dan mengingat.

b. Faktor Eksternal yang mempengaruhi persepsi, merupakan karakteristik dari linkungan dan obyek-obyek yang terlibat didalamnya. Elemen-elemen tersebut dapat mengubah sudut pandang seseorang terhadap dunia sekitarnya dan mempengaruhi bagaimana seseoarang merasakannya atau menerimanya. Sementara itu faktor-faktor eksternal yang mempengaruhi persepsi adalah : 
1. Ukuran dan penempatan dari obyek atau stimulus. Faktor ini menyatakan bahwa semakin besrnya hubungan suatu obyek, maka semakin mudah untuk dipahami. Bentuk ini akan mempengaruhi persepsi individu dan dengan melihat bentuk ukuran suatu obyek individu akan mudah untuk perhatian pada gilirannya membentuk persepsi.

2. Warna dari obyek-obyek. Obyek-obyek yang mempunyai cahaya lebih banyak, akan lebih mudah dipahami (to be perceived) dibandingkan dengan yang sedikit.

3. Keunikan dan kekontrasan stimulus. Stimulus luar yang penampilannya dengan latarbelakang dan sekelilingnya yang sama sekali di luar sangkaan individu yang lain akan banyak menarik perhatian.

4. Intensitas dan kekuatan dari stimulus. Stimulus dari luar akan memberi makna lebih bila lebih sering diperhatikan dibandingkan dengan yang hanya sekali dilihat. Kekuatan dari stimulus merupakan daya dari suatu obyek yang bisa mempengaruhi persepsi.

5. Motion atau gerakan. Individu akan banyak memberikan perhatian 
terhadap obyek yang memberikan gerakan dalam jangkauan pandangan dibandingkan obyek yang diam.

Factor lain yang mempengaruhi persepsi individu:

a. Primary Effect: Pentingnya Kesan Pertama

Kesan pertama merupakan faktor penting dalam proses persepsi manusia. Setiap orang dari kita pasti memiliki hari yang baik dan hari yang buruk dalam kehidupan kita, bahkan faktor baik dan buruk tersebut dapat mempengaruhi persepsi oranglain terhadap kita. Apakah ketika kita membuat kesan pertama kita pada hari yang baik atau yang buruk.

Informasi pertama yang kita dapat dari orang lain cenderung mempengaruhi pendapat kita terhadap mereka dibandingkan informasiinformasi selanjutnya. Inilah yang disebut primacy effect sebagai contoh : ketika Budi bertemu dengan Anto seorang yang sangat hebat di bidang Fisika, Budi melihat bahwa Anto ini adalah seorang siswa SMA yang jago Fisika dan menjadi juara kelas, serta ramah dengan siapapun. Kesan 
pertama Budi akan positif. Setelah itu ketika ia bertemu lagi dengan Anto di kafe, dimana ia duduk sendiri dan setengah mabuk, Budi melihat sisi lain dari Anton. Namun, karena kesan pertama bertemu adalah positif, Budi mengabaikan hal tersebut dan mengira bahwa dia berada di bar sendirian akrena adanya sesuatu yang negatif yang menimpanya. Dan Sebaliknya, ketika mereka bertemu, kesan pertama negatif. Dan ketika keesokan harinya mereka bertemu kesan yang terlihat cukup possitif, namun karena awalnya negatif. Maka kesan yang mendominasi justru yang negatif.

Efek Kesan pertama ( primacy effect) tidak selalu penting dan akan sangat berkurang dalam tiga kondisi sebagi berikut :

1. Prolonged expose ( paparan yang berkepanjangan)

Prolonged expose cenderung mengurangi pentingnya kesan pertama. Walaupun, membuat kesan pertama yang baik pada hari pertama bekerja sangat penting, namun anda tidak perlu kuatir karena rekan kerja 
anda akan mengetahui diri anda yang sebernarnya dengan mengumpulkan informasi dalam jangka panjang, sehingga hal tersebut dapat menghilangkan kesan pertama anda.

2. Passege of time (Berlalunya waktu)

Seperti yang lainnya, kesan pertama akan dilupakan seiring berjalannya waktu. Jika adanya jangka waktu yang panjang antara kesan pertama dengan kesan selanjutnya, kesan yang terbaru yang lebih mendominasi

3. Knowledge of primacy effects

Ketika seseorang telah diperingati untuk tidak terpengaruh dengan kesan pertama. Maka primacy effect dapat dikurangi. Dengan adanya Manager atau profesi lainnya yng mampu mempersepsi seseorang secara akurat dapat mengajarkan tentang bahayanya primacy effect, sehingga mengurangi pentingnya primacy effect dalam proses persepsi mereka. 
b. Proximity (kedekatan geografis)

Ini merupakan sebuah hal penting, namun tidak romantis yang menyebabkan ketertarikan. Sangatlah susah untuk jatuh cinta dengan seseroang yang jarang kita temui. Kedekatan fisik dan interpersonal yang dihasilkan sangat penting untuk perkembangan ketertarikan. Sebagai contoh : kamu akan lebih ramah dengan tetangga yang tinggal dekatmu daripada oranglain yang tinggal ditempat yang jauh darimu. Hal ini dikarenakan Proximity meningkatkan ketertarikan, dan pertemuan yang berulang-ulang terhadap seseorang akan meningkatkan rasa suka kita (Zajonc,1968).

c. Mutual liking

Manusia akan lebih tertarik pada orang yang menyukainya daripada orang yang tidak. Menyukai seseorang biasanya akan mengarah pada balasan perasaan yang sama. Mengapa demikian? Alasan pertamanya adalah ketika kita menyukai seseorang, kita akan terlihat lebih menarik secara fisik, khususnya apabila ada sedikit nafsu di dalamnya. 
Banyak orang yang berkata bahwa jatuh cinta membuat kamu terlihat lebih cantik dan itu benar. Matamu akan lebih menarik, pupil mata akan lebih terbuka ketika kamu melihat seseorang yang kamu anggap menarik secara seksual, dan orang lain akan melihat bahwa pupil yang terbuka sangat menarik secara seksual. Selain itu postur dan gerakan tubuh akan lebih menarik juga. Dengan kata lain, kamu akan lebih memikat secara fisik ketika kamu tertarik dengan seseorang. Alasan yang lain adalah ketika kamu menyukai seseorang, kamu akan bersikap lebih baik terhadap orang tersebut dan bersikap baik membuat kamu kelihatan lebih menarik. Beberapa penelitian menunjukkan bahwa kita cenderung menyukai orang yang memuji kita atau orang yang banyak membantu kita. Akan tetapi akan ada dampak negatif dari pujian dan perhatian yang terlalu banyak. Apabila terlalu berlebihan, khususnya ketika orang tersebut mengira kamu tidak ikhlas dan mempunyai motif yang egois dari pemberian, pujian, dan bantuanmu, hal itu tidak akan mengarahkan perasaannya ke rasa suka dan malah akan membencinya 
4. Proses persepsi

Salah satu pandangan yang dianut secara luas menyatakan bahwa psikologi, sebagai telaah ilmiah, berhubungan dengan unsur dan proses yang merupakan prantara rangsangan di luar organisme dengan tanggapan fisik organisme yang dapat diamati terhadap rangsangan. Menurut rumusan ini, yang dikenal dengan teori rangsanganrangasangan(stimulus-respons/SR), persepsi merupakan bagian dari keseluruhan proses yang menghasilkan tanggapan setelah rangsangan diterapkan keapada manusia. Subproses psikologi lainnya yang mungkin adalah pengenalan,prasaan, dan penalaran. persepsi dan kognisi diperlukan dalam semua kegiatan psikologis. Bahkan, diperlukan bagi orang yang paling sedikit terpengaruh atau sadar akan adanya rangsangan menerima dan dengan suatu cara menahan dampak dari rangsangan. Rasa dan nalar bukan merupakan bagian yang perlu dari setiap situasi rangsangatanggapan, sekalipun kebanyakan tanggapan individu yang sadar dan bebas terhadap satu rangsangan atau terhadap satu bidang rangsangan sampai tingkat tertentu dianggap dipengaruhi oleh akal atau emosi atau keduaduanya. 
Perpepsi, pengenalan, penalaran, dan perasaan kadang-kadang disebut variabel psikologis yang muncul di antara rangsangan dan tanggapan. Sudah tentu, ada pula cara lain untuk mengonsepsikan lapangan psikologi, namun rumus $S-R$ dikemukakan di sini karena telah diterima secara luas oleh para psikolog dan karena unsur-unsur dasarnya mudah dipahami dan digunakanoleh ilmu sosial lainnya (Hennessy, 1981:117)

Dari segi psikologi dikatakan bahwa tingkah laku seseorang merupakan fungsi dari cara dia memandang. Dalam proses persepsi, terdapat tiga komponan utama berikut:

1. Seleksi adalah proses penyaringan oleh indra terhadap rangsangan dari luar, intensitas dan jenisnya dapat banyak atau sedikit.

2. Interprestasi, yaitu proses mengorganisasikan informasi sehingga mempunyai arti bagi seseorang. Interprestasi dipengaruhi oleh berbagai faktor, seperti pengalaman masa lalu, sistem nilai yang dianut, motivasi, kepribadian, dan kecerdasan. Interprestasi juga bergantung pada kemampuan seseorang untuk mengadakan pengkatagoriaan informasi yang kompleks menjadi sarjana. 
3. Interprestasi dan persepsi kemudian ditrjemahkan dalam bentuk tingkah laku sebagai rekasi (Depdikbud, 1985), dalam Soelaeman, 1987). Jadi, proses persepsi adalah melakukan seleksi, interprestasi, dan pembulatan terhadap informasi yang sampai.

4. Jenis-jenis persepsi

Proses pemahaman terhadap rangsang atau stimulus yang diperoleh oleh indera menyebabkan persepsi terbagi menjadi beberapa jenis.

a. Persepsi visual

Untuk melihat contoh persepsi visual, silahkan lihat gambar-gambar disini. Persepsi visual didapatkan dari penglihatan. Penglihatan adalah kemampuan untuk mengenali cahaya dan menafsirkannya, salah satu dari indra. Alat tubuh yang digunakan untuk melihat adalah mata. Banyak binatang yang indra penglihatannya tidak terlalu tajam dan menggunakan indra lain untuk mengenali lingkungannya, misalnya pendengaran untuk kelelawar. Manusia yang daya penglihatannya menurun dapat menggunakan alat bantu atau menjalani operasi lasik untuk memperbaiki penglihatannya.

Persepsi ini adalah persepsi yang paling awal berkembang pada bayi, dan mempengaruhi 
bayi dan balita untuk memahami dunianya. Persepsi visual merupakan topik utama dari bahasan persepsi secara umum, sekaligus persepsi yang biasanya paling sering dibicarakan dalam konteks sehari-hari.

b. Persepsi auditori

Persepsi auditori didapatkan dari indera pendengaran yaitu telinga. Pendengaran adalah kemampuan untuk mengenali suara. Dalam manusia dan binatang bertulang belakang, hal ini dilakukan terutama oleh sistem pendengaran yang terdiri dari telinga, syaraf-syaraf, dan otak.

Tidak semua suara dapat dikenali oleh semua binatang. Beberapa spesies dapat mengenali amplitudo dan frekuensi tertentu. Manusia dapat mendengar dari $20 \mathrm{~Hz}$ sampai $20.000 \mathrm{~Hz}$. Bila dipaksa mendengar frekuensi yang terlalu tinggi terus menerus, sistem pendengaran dapat menjadi rusak

c. Persepsi perabaan

Persepsi perabaan didapatkan dari indera taktil yaitu kulit. Kulit dibagi menjadi 3 bagian, yaitu bagian epidermis, dermis, dan subkutis.

Kulit berfungsi sebagai alat pelindung bagian dalam, misalnya otot dan tulang; sebagai alat peraba dengan dilengkapi bermacam reseptor yang peka terhadap berbagai rangsangan; sebagai alat ekskresi; serta pengatur suhu tubuh. 
Sehubungan dengan fungsinya sebagai alat peraba, kulit dilengkapi dengan reseptor reseptor khusus. Reseptor untuk rasa sakit ujungnya menjorok masuk ke daerah epidermis. Reseptor untuk tekanan, ujungnya berada di dermis yang jauh dari epidermis. Reseptor untuk rangsang sentuhan dan panas, ujung reseptornya terletak di dekat epidermis.

d. Persepsi penciuman

Persepsi penciuman atau olfaktori didapatkan dari indera penciuman yaitu hidung. Penciuman, penghiduan, atau olfaksi, adalah penangkapan atau perasaan bau. Perasaan ini dimediasi oleh sel sensor tespesialisasi pada rongga hidung vertebrata, dan dengan analogi, sel sensor pada antena invertebrata. Untuk hewan penghirup udara, sistem olfaktori mendeteksi zat kimia asiri atau, pada kasus sistem olfaktori aksesori, fase cair. Pada organisme yang hidup di air, seperti ikan atau krustasea, zat kimia terkandung pada medium air di sekitarnya. Penciuman, seperti halnya pengecapan, adalah suatu bentuk kemosensor. Zat kimia yang mengaktifkan sistem olfaktori, biasanya dalam konsentrasi yang sangat kecil, disebut dengan bau.

e. Persepsi pengecapan

Persepsi pengecapan atau rasa didapatkan dari indera pengecapan yaitu lidah. Pengecapan 
atau gustasi adalah suatu bentuk kemoreseptor langsung dan merupakan satu dari lima indra tradisional. Indra ini merujuk pada kemampuan mendeteksi rasa suatu zat seperti makanan atau racun. Pada manusia dan banyak hewan vertebrata lain, indra pengecapan terkait dengan indra penciuman pada persepsi otak terhadap rasa. Sensasi pengecapan klasik mencakup manis, asin, masam, dan pahit. Belakangan, ahli-ahli psikofisik dan neurosains mengusulkan untuk menambahkan kategori lain, terutama rasa gurih (umami) dan asam lemak.

Pengecapan adalah fungsi sensoris sistem saraf pusat. Sel reseptor pengecapan pada manusia ditemukan pada permukaan lidah, langit-langit lunak, serta epitelium faring dan epiglotis.

5. Fenomena dalam persepsi

a. Persepsi bawah sadar (sublimical perception) Persepsi terhadap suatu objek dapat terjadi tanpa disengaja atau disadari oleh seseorang. Biasanya persepsi tersebut tertuju pada objek, gambar atau kata-kata yang ditampilkan di dalam waktu yang relatif singkat atau sedikit dalam rangkaian suatu peristiwa. Persepsi subliminal terjadi apabila stimulus yang tampaknya tidak diperhatikan atau tanpa disadari keberadaanya oleh seseorang namun secara diam-diam stimulus itu mempengaruhi perilaku orang yang bersangkutan dikemudian hari. 
Persepsi Subliminal terjadi ketika stimulus disajikan di bawah ambang batas atau Limen untuk kesadaran ditemukan untuk mempengaruhi pikiran, perasaan, atau tindakan . Istilah persepsi subliminal awalnya digunakan untuk menggambarkan situasi di mana rangsangan yang lemah dipandang tanpa kesadaran .

b. Ilusi atau kesalahan persepsi (error of perception) Kesalahan persepsi biasanya disebut ilusi (illusion) terjadi ketika seseorang mempersepsi suatu obje secara tidak tepat atau tidak sesuai dengan keadaan semestinya (realitas objektif).

1. Ilusi disebabkan faktor-faktor eksternal

Gambar pada cermin serta gaung suara adalah ilusi tipe ini. Gambar atau bayangan dicermin kelihatannya terletak dibelakang kaca, ini disebabkan dari arah itulah cahaya datang mengenai mata kita. Gaung datang dari arah yang berlawanan dengan posisi kita berdiri, karena di situ pula suara tidak masuk kedalam telinga kita.

2. Ilusi disebabkan kebiasaan

Rangsangan-rangsangan yang disajikan sesuai dengan kebiasaan kita dalam mengenali, kita akan lebih mudah menimbulkan ilusi bila otak kita bisa dengan pengindraan visual yang mengandalkan perspektif maka akan terjadi kesalahan. 
3. Ilusi karena kesiapan mental atau harapan tertentu

Jika kita kehilangan sesuatu dan ingin sekali menemukannya kembali. Anda akan sering melihat sesuatu yang mirip barang tersebut.

4. Ilusi karena kondisi rangsang terlalu kompleks

Bila rangsang yang diamati terlalu kompleks, maka rangsang tersebut dapat menutup-nutupi atau menyamarkan faktafakta objektif dari objek atau gejala tertentu.

c. Menghindar persepsi (perceptual defence) Fenomena menghindar atau menolak agar tidak terjadi suatu persepsi terhadap stimulus yang dihadirkan pada seseorang, Seringkali kita jumpai dalam kehidupan sehari-hari. Biasanya stimulus yang bermuatan emosi cenderung kurang siap untuk dipersepsikan daripada stimulus yang netral (Eysenck, 1984) contoh apabila kepada seseorang diucapkan kata tabu, cabul atau dapat membangkitkan kenangan masa lalu yang traumatis, maka ia cenderung akan menghindari untuk mempersepsi kata-kata itu. Biasanya dilakukan seseorang dengan menutup telinganya, memalingkan muka atau mengalihkan perhatiannya kepada pembicaraan yang lain untuk menghindari terjadinya persepsi terhadap ucapanucapan itu. Situasi ini mengakibatkan stimulus itu tidak berada dalam kesadaran penuh yang siap 
dipersepsikan oleh seseorang melainkan diambang kesadaran (threshold)

6. Pembedaan dengan sensasi

Istilah persepsi sering dikacaukan dengan sensasi. Sensasi hanya berupa kesan sesaat, saat stimulus baru diterima otak dan belum diorganisasikan dengan stimulus lainnya dan ingatan-ingatan yang berhubungan dengan stimulus tersebut. Misalnya meja yang terasa kasar, yang berarti sebuah sensasi dari rabaan terhadap meja.

Sebaliknya persepsi memiliki contoh meja yang tidak enak dipakai menulis, saat otak mendapat stimulus rabaan meja yang kasar, penglihatan atas meja yang banyak coretan, dan kenangan di masa lalu saat memakai meja yang mirip lalu tulisan menjadi jelek.

7. Dinamika Persepsi

Persepsi [perception] merupakan konsep yang sangat penting dalam psikologi, kalau bukan dikatakan yang paling penting. Melalui persepsilah manusia memandang dunianya. Apakah dunia terlihat "berwarna" cerah, pucat, atau hitam, semuanya adalah persepsi manusia yang bersangkutan. Persepsi harus dibedakan dengan sensasi [sensation]. Yang terakhir ini merupakan fungsi fisiologis, dan lebih banyak tergantung pada kematangan dan berfungsinya organorgan sensoris. Sensasi meliputi fungsi visual, audio, penciuman dan pengecapan, serta perabaan, 
keseimbangan dan kendali gerak. Kesemuanya inilah yang sering disebut indera.

Jadi, dapat dikatakan bahwa sensasi adalah proses manusia dalam dalam menerima informasi sensoris [energi fisik dari lingkungan] melalui penginderaan dan menerjemahkan informasi tersebut menjadi sinyal-sinyal "neural" yang bermakna. Misalnya, ketika seseorang melihat (menggunakan indera visual, yaitu mata) sebuah benda berwarna merah, maka ada gelombang cahaya dari benda itu yang ditangkap oleh organ mata, lalu diproses dan ditransformasikan menjadi sinyal-sinyal di otak, yang kemudian diinterpretasikan sebagai "warna merah".

Berbeda dengan sensasi, persepsi merupakan sebuah proses yang aktif dari manusia dalam memilah, mengelompokkan, serta memberikan makna pada informasi yang diterimanya. Benda berwarna merah akan memberikan sensasi warna merah, tapi orang tertentu akan merasa bersemangat ketika melihat warna merah itu, misalnya.

8. Determinasi Persepsi

Di samping faktor-faktor teknis seperti kejelasan stimulus [mis. suara yang jernih, gambar yang jelas], kekayaan sumber stimulus [mis. media multichannel seperti audio-visual], persepsi juga dipengaruhi oleh faktor-faktor psikologis. Faktor psikologis ini bahkan terkadang lebih menentukan bagaimana informasi/pesan/stimulus dipersepsikan. 
Faktor yang sangat dominan adalah faktor ekspektansi dari si penerima informasi sendiri. Ekspektansi ini memberikan kerangka berpikir atau perceptual set atau mental set tertentu yang menyiapkan seseorang untuk mempersepsi dengan cara tertentu. Mental set ini dipengaruhi oleh beberapa hal.

Ketersediaan informasi sebelumnya; ketiadaan informasi ketika seseorang menerima stimulus yang baru bagi dirinya akan menyebabkan kekacauan dalam mempersepsi. Oleh karena itu, dalam bidang pendidikan misalnya, ada materi pelajaran yang harus terlebih dahulu disampaikan sebelum materi tertentu. Seseorang yang datang di tengah-tengah diskusi, mungkin akan menangkap hal yang tidak tepat, lebih karena ia tidak memiliki informasi yang sama dengan peserta diskusi lainnya. Informasi juga dapat menjadi cues untuk mempersepsikan sesuatu.

Kebutuhan; seseorang akan cenderung mempersepsikan sesuatu berdasarkan kebutuhannya saat itu. Contoh sederhana, seseorang akan lebih peka mencium bau masakan ketika lapar daripada orang lain yang baru saja makan. Pengalaman masa lalu; sebagai hasil dari proses belajar, pengalaman akan sangat mempengaruhi bagaimana seseorang mempersepsikan sesuatu. Pengalaman yang menyakitkan ditipu oleh mantan pacar, akan mengarahkan seseorang untuk mempersepsikan orang lain yang mendekatinya dengan kecurigaan tertentu. Contoh lain yang lebih ekstrim, ada orang yang tidak bisa melihat warna merah [dia 
melihatnya sebagai warna gelap, entah hitam atau abuabu tua] karena pernah menyaksikan pembunuhan. Di sisi lain, ketika seseorang memiliki pengalaman yang baik dengan bos, dia akan cenderung mempersepsikan bosnya itu sebagai orang baik, walaupun semua anak buahnya yang lain tidak senang dengan si bos.

Faktor psikologis lain yang juga penting dalam persepsi adalah berturut-turut: emosi, impresi dan konteks.

a. Emosi; akan mempengaruhi seseorang dalam menerima dan mengolah informasi pada suatu saat, karena sebagian energi dan perhatiannya [menjadi figure] adalah emosinya tersebut. Seseorang yang sedang tertekan karena baru bertengkar dengan pacar dan mengalami kemacetan, mungkin akan mempersepsikan lelucon temannya sebagai penghinaan.

b. Impresi; stimulus yang salient / menonjol, akan lebih dahulu mempengaruhi persepsi seseorang. Gambar yang besar, warna kontras, atau suara yang kuat dengan pitch tertentu, akan lebih menarik seseorang untuk memperhatikan dan menjadi fokus dari persepsinya. Seseorang yang memperkenalkan diri dengan sopan dan berpenampilan menarik, akan lebih mudah dipersepsikan secara positif, dan persepsi ini akan mempengaruhi bagaimana ia dipandang selanjutnya

c. Konteks; walaupun faktor ini disebutkan terakhir, tapi tidak berarti kurang penting, malah mungkin 
yang paling penting. Konteks bisa secara sosial, budaya atau lingkungan fisik. Konteks memberikan ground yang sangat menentukan bagaimana figure dipandang. Fokus pada figure yang sama, tetapi dalam ground yang berbeda, mungkin akan memberikan makna yang berbeda.

9. Pengaruh Kebudayaan Terhadap Persepsi

Dalam pendekatan konvensional, persepsi masih dikaitkan dengan faktor-faktor saraf dan faalnya saja. Misalnya: persepsi tentang kedalaman (3 dimensi) di tentukan oleh pandangan dua mata (binokular) dimana terdapat perbedaan antara stimuli yang ditangkap antara retina kanan dan retina kiri (retinal disparity).

Contoh Pengaruh Kebudayaan Terhadap Persepsi

Pengaruh kebudayaan tersebut bisa kita lihat pada suku-suku Afrika primitif yang hanya terbiasa dengan lingkungan alamiah dimana karya-karya merekapun lebih banyak berbentuk lingkaran-lingkaran dan lengkungan-lengkungan, tidak akan mengalami gejala ilusi Muller-Lyer jika kepada meraka diperlihatkan kedua garis diatas karena persepsi mereka tidak dipengaruhi oleh kebiasaan melihat garisgaris dan sudut-sudut. Buat mereka, garis-garis pada gambar 1 dan 2 akan dipersepsikan sama panjang.

Pengaruh kebudayaan termasuk kebiasaan hidup, tampak juga dalam berbagai gejala hubungan manusia dengan lingkungan dalam kehudupan sehari- 
hari. Penduduk perkampungan kumuh di kotakota besar biasa menggunakan air kali untuk kepentingan mandi mencuci, dan kakus mempersepsikan air kali itu sebagai sesuatu hal yang masih dalam batas-batas optimal sehingga mereka menggunakan ai kali itu dengan enak saja. Sebaliknya orang biasa tinggal dipermukiman mewah, tidak mungkin akan menggunakan air kali itu. Dengan demikian ,jelaslah bahwa persepsi ditentukan oleh pengalaman dan pengalaman dipengaruhi oleh kebudayaan.

\section{B. Teori Atribusi}

\section{Pengertian}

Adapun pengertian atribusi menurut mereka adalah sebagai berikut (Malle, 2007 : 74) :

\section{Fritz Heider (1958)}

Fritz Heider adalah salah satu ahli psikologi yang pertama kali mendefinisikan istilah atribusi. Terdapat dua pengertian atribusi menurut Heider, yaitu atribusi sebagai proses persepsi dan atribusi sebagai penilaian kausalitas.

\section{a. Atribusi sebagai proses persepsi}

Menurut Heider, atribusi merupakan inti dari proses persepsi 
manusia. Lebih jauh Heider berpendapat bahwa manusia terikat dalam proses psikologis yang menghubungkan pengalaman subyektif mereka dengan berbagai obyek yang ada. Kemudian, berbagai obyek tersebut direkonstruksi secara kognitif agar menjadi sumbersumber akibat dari pengalaman perseptual. Sebaliknya, ketika orang mencoba untuk membayangkan sebuah obyek, maka mereka akan menghubungkan pengalaman tersebut ke dalam alam pikiran mereka. (Baca juga : Teori Perbandingan Sosial)

\section{b. Atribusi sebagai penilaian kausalitas}

Ketertarikan Heider pada kognisi sosial telah mengantarkannya pada perumusan atribusi selanjutnya. Menurutnya, kognisi sosial adalah proses dimana orang merasakan dan membuat penilaian tentang orang lain. Di sinilah kemudian muncul atribusi sebagai penilaian kausalitas yang menekankan pada penyebab orang berperilaku tertentu. 
Terdapat dua jenis atribusi kausalitas yaitu atribusi personal dan atribusi impersonal. Yang dimaksud dengan atribusi personal adalah penyebab personal atau pribadi yang merujuk pada kepercayaan, hasrat, dan intensi yang mengarahkan pada perilaku manusia yang memiliki tujuan. Sedangkan, atribusi impersonal adalah penyebab diluar pribadi yang bersangkutan yang merujuk pada kekuatan yang tidak melibatkan intensi atau tujuan. Untuk itu, dalam ranah persepsi sosial, orang akan berupaya untuk menjelaskan terjadinya sebuah perilaku. (Baca juga : Teori Sosial Kognitif)

\section{Edward E. Jones (1965)}

Edward E. Jones adalah salah seorang peneliti yang tertarik pada suatu penilaian yang terkadang diberikan oleh seseorang ketika mereka mengamati perilaku orang lain. Inferensi yang dibuat umumnya terkait dengan disposisi orang yang lebih stabil seperti sifat, sikap, dan nilai. Misalnya, kita melihat orang bertato dan bertampang seram dan kemudian kita 
langsung menyimpulkan bahwa orang tersebut adalah preman. Kita lebih suka membuat atribusi disposisi walaupun perilaku dalam situasi tertentu tidak menjamin simpulan yang dihasilkan.

\section{Para ahli psikologi sosial}

Para ahli psikologi sosial
menyatakan bahwa responsibility
attributions dan blame attributions
merupakan penilaian yang bersifat moral.
Ketika keluaran atau hasil negatif terjadi
maka orang akan mencoba untuk
menemukan siapa yang bertanggung
jawab terhadap keluaran tersebut dan
siapa yang harus disalahkan. Kerapkali,
responsibility attributions berhubungan
langsung dengan atribusi kausalitas
namun kadangkala lebih kompleks.
Responsibility attributions didasarkan
pada kausalitas dan apa yang seharusnya
dilakukan oleh seseorang.

\section{Asumsi Dasar}

Pada umumnya, teori atribusi menekankan pada bagaimana setiap individu menafsirkan berbagai kejadian dan bagaimana hal tersebut berkaitan dengan pemikiran dan perilaku mereka. Teori atribusi mengasumsikan bahwa orang mencoba untuk menentukan 
mengapa orang melakukan apa yang mereka lakukan. Orang akan berusaha untuk memahami mengapa orang lain melakukan sesuatu dan memberikan penyebab bagi perilaku.

Terkait dengan hal ini, Heider menyatakan bahwa orang dapat membuat dua atribusi yaitu atribusi internal dan atribusi eksternal. Atribusi internal adalah inferensi yang dibuat oleh seseorang tentang sikap, karakter, atau pribadi seseorang. Sementara itu, atribusi eksternal adalah inferensi yang dibuat seseorang terakit dengan situasi dimana ia berada.

\section{Teori-teori Atribusi}

Meskipun disebut sebagai teori atribusi, namun sejatinya teori atribusi meliputi beberapa macam teori atribusi yang telah dirumuskan oleh para ahli psikologi, diantaranya adalah teori atribusi Fritz Heider, teori atribusi Edward Jones dan Keith Davis, teori atribusi Harold Kelley, dan teori atribusi Bernard Weiner.

\section{a. Teori Atribusi Fritz Heider}

Fritz Heider adalah peneliti pertama yang mengenalkan teori atribusi saat teori-teori belajar dari pendekatan behaviorisme (contohnya teori operant 
conditioning), teori-teori memori dan teoriteori psikoanalisis mendominasi ranah psikologi akademis. Teori-teori tersebut jarang sekali digunakan untuk menjelaskan perilaku manusia. Sebaliknya, melalui teori atribusinya, Heider mencoba untuk menekankan bahwa mempelajari atribusi sangatlah penting karena atribusi memberikan pengaruh pada apa yang dirasakan dan apa yang dilakukan oleh manusia.

Heider juga merupakan peneliti pertama yang mengkaji tentang proses atribusi khususnya pada bagaimana seseorang membangun sebuah impresi atau kesan bagi orang lain. Menurutnya, impresi atau kesan ini dibangun melalui tuga tahapan proses yaitu pengamatan perilaku, menentukan apakah perilaku itu disengaja atau tidak, dan mengelempokkan perilaku ke dalam perilaku yang termotivasi secara internal atau eksternal. (Baca juga : Teori Interaksi Simbolik).

b. Teori Atribusi Edward Jones dan Keith Davis

Pada tahun 1965, Edward Jones dan Keith Davis mempublikasikan sebuah teori correspondent inference atau inferensi koresponden. Berdasarkan teori inferensi 
koresponden, kita cenderung menggunakan informasi tentang perilaku orang lain dan efeknya untuk menggambarkan sebuah inferensi koresponden dimana perilaku tersebut dikaitkan dengan karakteristik disposisi atau kepribadian. Hal ini dilakukan dengan cara-cara sebagai berikut :

1. Pertama, mengidentifikasi maksud dari efek perilaku seseorang. Kita cenderung untuk menarik inferensi koresponden jika perilaku tersebut muncul dengan disengaja dibandingkan dengan tidak disengaja

2. Kedua, kita cenderung memutuskan ada korespondensi bila dampak dari perilaku tersebut tidak diinginkan secara sosial.

Inferensi koresponden dipengaruhi oleh tiga faktor utama yaitu efek-efek yang tidak umum, keinginan sosial, dan kebebasan memilih.

1. Efek-efek tidak umum - berbagai elemen pola tindakan yang tidak dibagi dengan pola tindakan alternative.

2. Keinginan sosial - perilaku yang tidak diinginkan secara sosial dapat menuntun pada inferensi koresponden 
dibandingkan dengan perilaku yang diinginkan secara sosial.

3. Kebebasan memilih - semakin besar kebebasan memilih maka semakin besar pula inferensi koresponden.

Teori inferensi koresponden memiliki keterbatasan, diantaranya adalah :

1. Teori ini mengasumsikan bahwa pengamat memutuskan kesamaan efek dengan membandingkan perilaku aktual aktor dengan beberapa tindakan yang tidak dipilih. Sejatinya, pengamat jarang mempertimbangkan tindakan yang tidak dipilih.

2. Kesimpulan koresponden kerapkali digambarkan bahkan ketika kita menilai tindakan seseorang tidak disengaja.

3. Proses yang terlibat dalam menarik kesimpulan tentang perilaku orang lain lebih kompleks daripada yang disarankan dalam teori inferensi koresponden.

\section{c. Teori Atribusi Harold Kelley}

Harold Kelley adalah salah satu ahli yang mengembangkan teori atribusi lebih lanjut yang dikenal dengan model kovarians Kelley. Model ini merupakan teori atribusi dimana orang membuat kesimpulan sebab 
akibat untuk menjelaskan mengapa orang lain dan diri kita berperilaku dengan cara tertentu. Hal ini berkaitan dengan persepsi sosial dan persepsi diri.

Prinsip kovariasi menyatakan bahwa sebuah efek dikaitkan dengan salah satu penyebabnya yang mungkin dan berlebihan. Dalam artian bahwa perilaku tertentu dikaitkan dengan potensi penyebab yang muncul pada saat bersamaan. Prinsip ini berguna bila individu memiliki kesempatan untuk mengamati perilaku tersebut selama beberapa kali. Penyebab hasil dapat dikaitkan dengan orang (internal), stimulus (eksternal), keadaan, atau beberapa kombinasi dari faktor-faktor ini. Atribusi dibuat berdasarkan tiga kriteria, yaitu konsensus, keistimewaan, dan konsistensi.

1. Konsensus - menggambarkan bagaimana orang lain, dalam keadaan yang sama, akan berperilaku.

2. Konsistensi - merujuk pada apakah orang yang diamati akan berperilaku dengan cara yang sama, dalam situasi yang sama, setiap waktu.

3. Keistimewaan - merujuk pada berbagai variasi dalam mengamati perilaku orang lain dalam situasi yang berbeda. 


\section{d. Teori Atribusi Bernard Weiner}

Bernard Weiner mengembangkan sebuah kerangka kerja teoretis yang sangat berpengaruh dalam psikologi sosial hingga kini. Teori atribusi yang dikembangkan oleh Weiner lebih menekankan pada pencapaian. Menurut Weiner, faktor-faktor penting yang mempengaruhi atribusi adalah kemampuan, upaya atau usaha, kesulitasn tugas, dan keberuntungan. Atribusi dikelompokkan ke dalam tiga dimensi kausalitas, yaitu :

a. Locus of control - internal dan eksternal

b. Stability - apakah penyebab berubah setiap waktu atau tidak

c. Controllability - penyebab seseorang dapat mengendalikan keterampilan dan penyebab seseorang tidak dapat mengendalikan tindakan orang lain dan lain-lain

\section{Kesalahan dalam Atribusi}

Terdapat beberapa jenis kesalahan dalam atribusi, diantaranya adalah kesalahan atribusi yang mendasar, bias melayani diri sendiri, atribusi defensif, dan efek faktor pengamat.

\section{a. Kesalahan atribusi yang mendasar}


Kesalahan atribusi yang umum di mana orang terlalu menekankan perilaku personal atau disposisi (internal) perilaku negatif orang lain atau hasil buruk dan meremehkan faktor situasional (eksternal). Ketika menafsirkan tindakan atau hasil positif orang lain, bagaimanapun orang terlalu menekankan penyebab situasional dan meremehkan penyebab disposisi. Contoh kesalahan atribusi yang mendasar adalah "Jika kamu gagal, maka berarti kamu bodoh". Dari contoh tersebut terlihat bahwa terdapat kecenderungan untuk merendahkan peran disposisi atau faktor internal atau faktor-faktor pribadi. Merujuk apa yang dinyatakan oleh Heider bahwa orangorang adalah prototipe dari asal usulnya maka dengan memandang orang sebagai sebuah prototipe dari asal usulnya sejatinya menuntun kita pada kesalahan atribusi yang mendasar.

\section{b. Bisa melayani diri sendiri}

Kesalahan

dimana

individu

mengaitkan kesuksesan dan kegagalan mereka dengan faktor yang berbeda. Keberhasilan seseorang dan hasil positif dikaitkan dengan karakteristik internal dan disposisi sedangkan kegagalan seseorang atau hasil negatif dianggap berasal dari sebab eksternal dan situasional. 


\section{c. Atribusi defensif}

Kecenderungan untuk menyalahkan korban atas kemalangan mereka sendiri. Atribusi defensif dapat disebut sebagai pengembangan dari kesalahan atribusi yang mendasar.

\section{d. Efek aktor pengamat}

Karena adanya perbedaan perspektif dan perbedaan informasi tentang suatu kejadian dan partisipan. Setiap aktor memiliki informasi yang lebih tentang perilaku di masa lalu dan lebih waspada terhadap faktor-faktor situasional dibandingkan pengamat. Ketika pengamat memiliki informasi yang lebih tentang seseorang dan situasi, maka mereka akan menjadi kurang rawan terhadap kecenderungan tersebut.

\section{Kelebihan dan Kekurangan Teori Atribusi}

Teori atribusi pun dipandang memiliki kelebihan dan kekurangan. Adapun kelebihan dan kekurangan teori atribusi adalah sebagai berikut :

\section{a. Kelebihan teori atribusi}


1. Teori atribusi menyediakan kemampuan dalam memberikan prediksi guna membantu kita mengatasi semua yang ditawarkan oleh kehidupan.

2. Teori atribusi efektif dalam memprediksi perilaku ketika identifikasi penyebabnya dilakukan dengan benar.

\section{b. Kekurangan teori atribusi}

1. Kesimpulan yang tidak akurat dapat menyebabkan penilaian yang salah.

2. Dapat menimbulkan pengharapan adanya perilaku tertentu dari diri sendiri atau orang lain yang bisa saja tidak akan menjadi kenyataan.

3. Dalam teori atribusi, berbagai penyebab lain mungkin diabaikan.

4. Dalam teori atribusi, kesimpulan yang dibuat oleh seseorang kemungkinan besar menjadi bias karena cenderung melestarikan citra dirinya.

\section{Emosi}

\section{Pengertian}

Emosi (emotion) yakni perasaan intens yang diarahkan kepada seseorang atau sesuatu. Kebanyakan para ahli percaya bahwa emosi lebih cepat datang dan pergi 
dibandingkan suasana hati. Seperti kompleksitas program komputasi afektif, psikolog mencoba mengidentifikasi emosi dasar dengan mempelajari ekspresi wajah, tetapi mereka menemukan bahwa proses itu sulit.

Menurut Fred Luthans (2005):[3], Emosi merupakan reaksi terhadap sebuah objek, bukan suatu trait. Emosi ditujukan pada objek khusus, anda menunjukkan emosi saat senang terhadap sesuatu, marah pada seseorang, takut pada sesuatu. Menurut teori Darwin dalam psikologi evolusioner menyatakan, kita harus mengalami emosi; apakah emosi positif atau emosi negatif, karena hal ini berguna terhadap suatu tujuan.

\section{Ciri Emosi}

Terdapat empat ciri emosi, yakni:

a. Pengalaman emosi yang bersifat pribadi

b. Adanya perubahan aspek jasmani

c. Ekspresi

d. Motif

\section{Perkembangan Emosi}

Individu berkembang, dan perkembangannya meliputi semua aspek 
kepribadian termasuk emosi. Oleh sebab itu emosi juga dapat dipengaruhi oleh kebudayaan, dalam perkembangan emosi terdapat pola-pola ekspresi dan pengendalian emosi, seperti:

1. Spontanitas dan pengendalian

2. Pernyataan konstruksi dan penekanan

3. Ekspresi langsung dan tersembunyi

\section{Fungsi Emosi}

Banyak observasi yang menyatakan bahwa rasionalitas dan emosi saling bertolak belakang dan jika ditampilkan emosinya, anda akan bertindak tidak rasional. Perspektifperspektif ini menyatakan bahwa demonstrasi atau bahkan pengalaman emosi dapat menyebabkan kita terlihat lemah, rapuh atau tidak rasional. Meskipun demikian, riset semakin menunjukkan bahwa emosi sebenarnya penting untuk penalaran rasional.

\section{Pengaturan Emosi}

Pengaturan emosi (emotion regulation), merupakan kecerdasan emosional tetapi saat ini semakin dipelajari sebuah konsep terpisah. Para peneliti dari pengaturan emosi sering mempelajari strategi yang mungkin digunakan orang untuk mengubah 
emosi. Teknik lain dengan potensi atas pengaturan emosi yakni dengan pengakuan. 


\section{BAB 4}

\section{Evaluasi, Umpan Balik, Penghargaan}

\section{A. Konsep Evaluasi Kinerja}

1. Konsep evaluasi adalah:

a. Mengumpulkan informasi

b. Menggunakan standar atau kriteria dalam evaluasi

c. Menarik kesimpulan, menetapkan suatu keputusan yang berguna yang dapat diaplikasikan pada semua situasi yang dihadapkan pada pimpinan organisasi.

Evaluasi dalam konteks manajemen terutama digunakan untuk membantu memilih dan merancang kegiatan yang akan datang. Studi evaluasi dapat menilai atau menduga keadaan yang dihasilkan suatu kegiatan dalam hal ini perubahan organisasi (mencakup keluaran/output dan hasil/outcome) dan distribusi manfaat diantara berbagai kelompok sasaran, dan dapat menilai efektivitas biaya dari proyek dibanding dengan pilihan lainnya. Jika kegiatan tidak mempunyai sistem evaluasi yang efektif, bahaya akan meningkat untuk melanjutkan kegiatan yang tidak menghasilkan manfaat yang diinginkan. Evaluasi diperlukan untuk melihat kesenjangan antara "harapan dan kenyataan". Hal yang sangat dipentingkan dalam semua kegiatan evaluasi adalah kesempurnaan dan keakuratan data. Evaluasi pada dasarnya merupakan kajian yang merupakan 
kegiatan mencari faktor-faktor penyebab timbulnya permasalahan, bukan hanya sekedar gejala yang tampak dalam permukaan. Karena itu evaluasi merupakan kegiatan diagnostik, menjelaskan interpretasi hasil analisis data dan kesimpulan.

Ada sebuah ungkapan yang menyatakan bahwa dunia akan selalu berubah, masyarakat berubah, lingkungan berubah dan semuanya berubah. Pendek kata tidak ada yang abadi kecuali perubahan itu sendiri. Organisasi pemerintah sebagai sebuah organisasi terbuka suka atau tidak suka akan menghadapi perubahanperubahan tersebut. Untuk itu ia harus terus menerus menyesuaikan diri dengan perubahanperubahan yang terjadi dilingkungan strategisnya. Dalam rangka mewujudkan organisasi berkinerja tinggi, langkah akhir dalam proses yang harus dilakukan adalah tahap evaluasi terhadap kinerja organisasi, sebagai upaya menuju organisasi berkinerja tinggi.

Proses evaluasi terhadap kinerja organisasi ini penting dilakukan, karena tanpa evaluasi tidak akan diketahui sampai sejauhmana organisasi tersebut telah efektif melakukan perubahan menuju organisasi berkinerja tinggi. Bisa dikatakan bahwa evaluasi terhadap kinerja organisasi pada hakekatnya adalah sebuah usaha untuk mengetahui "di mana kita nyatanya berada" dan "di mana kita seharusnya berada". Dari hasil evaluasi bisa diketahui apa kekurangan dalam mewujudkan organisasi berkinerja tinggi dan kemudian 
dapat dilakukan langkah-langkah intervensi untuk memperbaiki kondisi yang ada.

Selanjutnya sebagai indikator organisasi berkinerja tinggi dapat diukur dari hasil kerja organisasi (kinerja) organisasi itu sendiri. Bila hasil evaluasi ternyata menunjukkan kinerja yang tinggi berarti organisasi tersebut telah berhasil melakukan perubahan menjadi organisasi berkinerja tinggi. Akan tetapi sebaliknya bila hasil evaluasi menunjukkan kinerja yang belum memuaskan, maka perlu dicari permasalahan apa yang menghambat terwujudnya organisasi berkinerja tinggi.

Untuk mengevaluasi kinerja sebuah organisasi bisa digunakan beberapa pendekatan. Pendekatan tersebut antara lain:

1. Pendekatan pencapaian tujuan

Pendekatan ini merupakan pendekatan yang paling umum digunakan dalam menilai kinerja organisasi, dimana output dan atau hasil yang ada/dicapai dibandingkan dengan hasil sebelumnya dan rencana/target yang telah ditetapkan. Dengan kriteria ini kinerja organisasi ditentukan dengan seberapa jauh pencapaian tujuan organisasi.

Untuk bisa menggunakan pendekatan ini, ada beberapa hal yang harus dipenuhi, antara lain: 
a. Organisasi mempunyai tujuan akhir yang jelas, yang tercermin dari visi dan misi yang dimiliki

b. Tujuan-tujuan tersebut diidentifikasi dan ditetapkan dengan baik agar dapat dimengerti

c. Tujuan-tujuan tersebut sedikit saja agar mudah dikelola

d. Ada konsensus untuk mencapai tujuan-tujuan tersebut.

e. Kemajuan kearah pencapaian tujuan tersebut dapat diukur.

2. Pendekatan Sistem/Proses Internal

Organisasi yang berkinerja tinggi harus memiliki proses internal "yang sehat". Organisasi memiliki proses internal yang sehat jika arus informasi berjalan baik, pegawai mempunyai loyalitas, komitmen, kepuasan kerja dan saling percaya. Kriteria yang lain adalah minimalnya konflik yang tidak perlu terjadi serta tidak ada manuver politik yang merusak dari para anggota. Selain itu, pendekatan ini lebih menekankan kriteria yang akan meningkatkan kelangsungan hidup jangka panjang dari organisasi, seperti memperoleh sumber daya, mempertahankan dirinya secara internal dan berintegrasi dengan lingkungan eksternalnya. Tujuan akhir tidak diabaikan, tetapi hanya dipandang sebagai satu elemen di dalam kumpulan kriteria yang lebih kompleks. Pendekatan ini lebih menekankan pada cara untuk mencapai tujuan. Hal-hal tersebut di atas didasarkan pada asumsiasumsi sebagai berikut : 
a. Organisasi terdiri dari sub-sub bagian yang saling berhubungan, dimana jika salah satu bagian mempunyai kinerja yang jelek akan berpengaruh terhadap keseluruhan organisasi.

b. Interaksi yang berhasil dengan lingkungan, sehingga manajemen tidak boleh gagal dalam mempertahankan hubungan baik dengan pelanggan, serikat pekerja, dan lainnya.

c. Kelangsungan hidup membutuhkan sumber daya, oleh karena itu harus dilakukan penggantian terus menerus terhadap bahan baku, lowongan/ kekurangan pegawai diisi, perubahan pelanggan diantisipasi dan sebagainya.

Pendekatan sistem ini akan sangat berguna jika ada hubungan yang jelas antara masukan (input) dan keluaran (out-put) dan sebaliknya ada beberapa kendala karena kesulitan mengembangkan alat ukur, misalnya untuk melihat kejelasan komunikasi intern.

3. Pendekatan Kepuasan Konstituen Strategis

Organisasi tergantung dan sekaligus mempengaruhi hidup orang-orang atau pihak di luar organisasi. Oleh karena itu tingkat kepuasan tiap-tiap pihak yang terlibat merupakan kriteria penting bagi kinerja organisasi. Dengan pendekatan ini organisasi pemerintah dikatakan efektif dan atau berkinerja tinggi jika dapat memenuhi tuntutan dari konstituen yang mendukung kelanjutan eksistensi organisasi tersebut. 
Yang dimaksud dengan konstituen disini adalah orang atau sekelompok orang yang mempunyai pengaruh terhadap kelangsungan hidup organisasi, seperti penyedia sumber daya, pelanggan dan sebagainya Dan hal tersebut penting kiranya bagi organisasi mempunyai kemampuan untuk mengidentifikasi konstituennya yang penting. Organisasi mampu menilai pola preferensi konstituen tersebut dan mampu memenuhi tuntutannya serta pada akhirnya organisasi harus mengejar sejumlah tujuan yang dipilih sebagai respon terhadap kelompok-kelompok kepentingan.

Pendekatan ini akan sangat berguna ketika konstituen mempunyai pengaruh yang kuat terhadap organisasi. Seperti yang terjadi sekarang ini dimana masyarakat, Lembaga Swadaya Masyarakat dan Dewan Perwakilan Rakyat begitu kuat tuntutannya kepada pemerintah (baca: organisasi pemerintah) untuk bisa memberikan pelayanan yang sebaikbaiknya. Karena adanya tuntutan tersebut organisasi pemerintah diharapkan menanggapi dan memenuhi tuntutan konstituen tersebut.

Ada beberapa kesulitan yang mungkin akan dihadapi ketika menggunakan pendekatan ini. Penentuan konstituen strategis pada lingkungan yang besar pada prakteknya sangat sulit, karena lingkungan berubah dengan cepat. Hal lain adalah pada masingmasing bagian/unit organisasi bisa saja mempunyai konstituen strategis yang berbeda. Dengan kondisi ini 
dengan sendirinya organisasi akan kesulitan menetapkan konstituen mana yang harus dipenuhi tuntutannya.

4. Pendekatan Faktor Bersaing

Pada pendekatan ini seluruh variabel yang mempengaruhi efektivitas organisasi diidentifikasi, kemudian menentukan bagaimana variabelvariabel tersebut saling berhubungan. Hal ini dilakukan karena menurut pendekatan ini, tidak ada pendekatan/kriteria yang paling baik untuk menilai kinerja organisasi. Tidak ada tujuan tunggal yang dapat disetujui semua orang dan tidak ada konsensus yang menetapkan tujuan mana yang harus didahulukan. Oleh karena itu berbagai pendekatan tersebut dikonsolidasikan/dikombinasikan sehingga membentuk kumpulan dasar nilai bersaing.

Dari kombinasi yang dilakukan didapat tiga kumpulan dasar nilai bersaing sebagai berikut :

a. Fleksibilitas versus kontrol. Dalam tiap organisasi dibutuhkan adanya fleksibilitas dan sekaligus kontrol yang merupakan dimensi yang saling berlawanan. Fleksibilitas menghargai inovasi, penyesuaian dan perubahan mengikuti perubahan dalam lingkungan, sedangkan kontrol lebih menyukai stabilitas, ketentraman dan kemungkinan prediksi. 
b. Kepentingan manusia versus kepentingan organisasi. Dalam tiap organisasi dimana didalamnya terdiri dari manusia, akan selalu ada persaingan dimana manusia (sebagai individu/kelompok kecil individu) mempunyai kepentingan yang terkadang berbenturan dengan kepentingan organisasi. Dari hal ter sebut ter jadi persaingan apakah penekanan lebih terhadap kebutuhan dan kesejahteraan manusia atau pengembangan dan produktivitas organisasi.

c. Cara/proses versus tujuan/hasil. Kondisi ideal dari tiap organisasi adalah cara/proses berjalan dengan baik dalam arti sinergi dari tiap orang/unit berjalan baik sehingga tujuan organisasi tercapai dengan baik.

Namun demikian ada kalanya kondisi ideal tersebut tidak terwujud sehingga organisasi perlu menentukan sikap, apakah memberi penekanan lebih terhadap cara/proses internal (jangka panjang) atau penekanan terhadap tujuan akhir (yang penting tujuan tercapai) dan jangka pendek. Ketiga kumpulan tersebut kemudian dikombinasikan sebagaimana terlihat pada Tabel 1 berikut :

2. Indikator dan Metode Evaluasi Kinerja Organisasi

Untuk melakukan evaluasi terhadap kinerja organisasi perlu ditentukan indikator yang akan diukur. Indikator ini bisa di break-down dari kombinasi pendekatanpendekatan yang telah dikemukakan 
sebelumnya. Selain itu indikator dapat pula dilihat dari beberapa metode pengukuran kinerja yang selama ini dikenal seperti Common Assessment Framework (CAF) dan Baldrige National Quality Program (BNQP).

1. Common Assessment Framework (CAF)

CAF merupakan alat untuk mengukur organisasi (self assessment) di sektor publik. CAF dikembangkan oleh Directors-General of Public Administration dari negara anggota Uni Eropa untuk mendukung pengenalan ide dan prinsip-prinsip total quality management (TQM) di bidang sektor publik di Uni Eropa dan sekitarnya.

CAF terdiri dari 9 kriteria evaluasi yang secara bersama-sama membentuk sebuah framework yang logis dan menyeluruh, dan memungkinkan untuk dilakukannya pengukuran pada kegiatan dan tindakan yang relevan, dan kinerja dari organisasi sektor publik. Empat kriteria digunakan untuk mengukur kinerja enabler (apa yang dilakukan organisasi untuk mencapai hasil yang ekselen). Kemudian, lima kriteria digunakan untuk mengukur results (hasil-hasil yang dicapai organisasi).

Kriteria yang masuk dalam kategori Enabler adalah : 
a. Kriteria 1: Kepemimpinan, yaitu bagaimana pimpinan dan manajer mengembangkan dan memfasilitasi pencapaian misi dan visi dari organisasi publik.

b. Kriteria 2: Kebijakan dan Strategi, yaitu bagaimana organisasi menerapkan misi dan visinya melalui strategi yang berfokus pada stakeholder yang jelas, didukung oleh kebijakan, tujuan yang telah direncanakan, target dan proses-proses yang relevan.

c. Kriteria 3: Manajemen Sumber Daya Manusia yaitu bagaimana organisasi mengelola, mengembangkan dan menyebarkan pengetahuan dan potensi orangorangnya secara maksimal pada tingkat individu, kelompok, maupun organisasi.

d. Kriteria 4: Sumber-sumber dan Kemitraan Eksternal, yaitu bagaimana organisasi merencanakan dan mengelola kemitraan eksternal dan sumber-sumber internalnya untuk mendukung kebijakan dan strateginya, dan proses operasinya yang efektif.

Kriteria yang masuk dalam kategori Results adalah :

a. Kriteria 5: Manajemen Proses dan Perubahan, yaitu bagaimana organisasi mendisain, mengelola dan meningkatkan prosesnya untuk mendukung kebijakan dan strateginya, dan secara penuh memuaskan para pengguna jasa dan stakeholdernya. 
b. Kriteria 6: Hasil-hasil yang berorientasi pada pengguna jasa/masyarakat, yaitu hasil apa yang dicapai organisasi dalam usahanya untuk memenuhi kebutuhan dan harapan para pengguna jasa dan masyarakat dengan hasil-hasil (out-comes) external-nya.

c. Kriteria 7: Hasil-hasil Manusia (Pegawai), yaitu hasilhasil yang dicapai organisasi dalam kaitannya dengan kepuasan para pegawainya.

d. Kriteria 8: Dampak pada masyarakat, yaitu apa yang dicapai organisasi dalam memuaskan kebutuhan dan harapan dari masyarakat pada tingkat lokal, nasional, dan internasional (sesuai dengan cakupan organisasi).

e. Kriteria 9: Hasil-hasil Kinerja Kunci, yaitu apa yang dicapai organisasi dalam hubungannya dengan mandat dan tujuan-tujuan khususnya dan dalam memuaskan kebutuhan dan harapan dari setiap orang.

2. Baldrige National Quality Program (BNQP) BNQP adalah sebuah program yang dilaksanakan oleh National Institute of Standards and Technology (NIST), sebuah lembaga federal dibawah Commerce Department's Technology Administration. Program ini ditujukan untuk meningkatkan tingkat kompetisi, kualitas, produktifitas dan kinerja organisasi-organisasi di Amerika Serikat. Adapun kriteria-kriteria yang dievaluasi melalui metode ini dibangun berdasarkan seperangkat nilai dan konsep yang saling berhubungan sebagai berikut: 
a. Visionary leadership, yaitu seorang pemimpin harus menyusun arah, sistim nilai yang jelas serta pengharapan yang tinggi bagi organisasinya. Arah, sistim nilai dan pengharapan harus seimbang terhadap keseluruhan kebutuhan stakeholder. Selain itu pemimpin harus bisa juga menjamin bahwa pada penyusunan strategi, sistem dan metode menunjang pencapaian hasil yang terbaik, mendorong inovasi serta membangun pengetahuan dan kemampuan pegawai.

b. Customer-driven excellence, yaitu sebuah konsep strategis dalam menghadapi keinginan customer serta pasar. Kualitas dan kinerja dinilai oleh customer organisasi. Oleh karena itu prinsip ini mempunyai dua komponen, yang pertama kemampuan memahami kemauan customer saat ini dan kedua, antisipasi terhadap kemauan customer dimasa depan serta perkembangan pasar.

c. Organizational and personal learning, yaitu dalam pencapaian level tertinggi dari kinerja organisasi dibutuhkan organizational and personal learning agar dapat mengikuti perubahan-perubahan yang terjadi di dalam organisasi.

d. Valuing employees and partners, yaitu peduli pada peningkatan pengetahuan, keahlian, kreativitas dan motivasi para pegawai dan relasi kerja.

e. Ability yaitu sebuah kemampuan untuk perubahan yang cepat dan fleksibilitas.

f. Focus on the future yaitu orientasi yang kuat akan masa depan dan kemauan membentuk komitmen jangka panjang dengan stakeholder. Perencanaan 
organisasi harus mempertimbangkan banyak faktor seperti harapan customer, peluang bisnis yang baru, globalisasi, perkembangan teknologi dan sebagainya.

g. Managing for innovation. Dengan prinsip ini inovasi adalah melakukan perubahan yang berarti untuk meningkatkan kualitas produk, servis dan proses yang memberi nilai tambah baru bagi seluruh stakeholder. Inovasi harus mampu membimbing organisasi menuju pada tingkat lain dari kinerja yang telah dicapai.

h. Management by fact, yaitu ketergantungan organisasi pada pengukuran dan analisis kinerja. Dengan analisa data dari hasil pengukuran kinerja dilakukan evaluasi dan perubahan untuk mendukung pencapaian tujuan.

i. Public responsibility and citizenship, yaitu penekanan tanggungjawab organisasi pada publik terkait dengan kesehatan dan keselamatan publik dan keselamatan lingkungan serta kemauan bertindak sebagai warga yang baik dengan mengutamakan tujuan-tujuan penting dimasyarakat seperti peningkatan pendidikan misalnya.

j. Focus on results and creating value yaitu pengukuran kinerja organisasi harus fokus pada pencapaian hasil. Pencapaian hasil digunakan sebagai penciptaan nilai tambah dan nilai penyeimbang antar stakeholder. Dengan menciptakan nilai tambah bagi para stakeholder, 
organisasi membangun loyalitas dan berkontribusi pada lingkungannya.

k. System perspective yaitu melihat organisasi sebagai suatu keseluruhan dari semua unsur-unsur yang ada untuk mencapai sukses yang diidamkan.

Bila dikaitkan dengan organisasi berkinerja tinggi, sebagaimana dikemukakan oleh Mark G. Popovich (1998), terdapat 8 karakteristik organisasi berkinerja tinggi diantaranya adalah :

a. Mempunyai misi yang jelas.

b. Menetapkan hasil yang akan dicapai dan berfokus pada pencapaian keberhasilan tersebut.

c. Memberdayakan para pegawainya.

d. Memotivasi individu-individu dalam organisasi untuk meraih sukses.

e. Bersifat fleksibel dan selalu dapat menyesuaikan diri dengan kondisi yang baru.

f. Selalu berkompetisi meningkatkan kinerja

g. Selalu menyempurnakan prosedur kerja demi untuk memenuhi kebutuhan pelanggan atau masyarakat.

h. Selalu berkomunikasi dengan stakeholders (pihak terkait dengan kinerja organisasi)

\section{B. Umpan Balik}

1. Pengertian Umpan Balik

Umpan balik adalah informasi tentang perilaku masa lalu, disampaikan pada saat ini dan dimungkinkan memengaruhi perilaku pada waktu 
yang akan datang. Penanggung jawab umpan balik adalah manajer dan pekerja, karena keduanya mendapat manfaat dari komunikasi (Schwartz,1999)

2. Fungsi Umpan Balik

a. Fungsi Instruksional: apabila mengklarifikasi atau memperjelas peran/perilaku baru. Contoh: manajer yang menegur bawahan karena tidak mampu memenuhi targetnya, dan selanjutnya memberi petunjuk tentang bagaimana memperbaiki kinerja bawahan.

b. Fungsi Motivasional: apabila digunakan sebagai alat pemberian penghargaan (reward).

3. Umpan Balik Nontradisional

Beberapa umpan balik nontradisional antara lain:

a. Upward feedback (Kreitner dan Kinicki)

b. 360-degree feedback (Greenberg dan Baron)

c. Terdapat 4 pendekatan umpan balik: 360- degree feedback, bidirectional evaluation,effectiveness enhancement systems dan using your head no system.

6 Alasan umpan balik nontradisional :

a. Sistem penilaian kinerja tradisional menciptakan ketidakpuasan yang sangat luas di kalangan pekerja, 
b. Struktur organisasi berbasis tim menggantikan struktur hierarki tradisional,

c. Sistem penilai jamak dinilai membuat umpan balik lebih sah (valid),

d. Teknologi jaringan komputer memfasilitasi sistem penilai jamak,

e. Umpan balik dari bawah ke atas berhubungan baik dengan kecenderungan manajemen partisipatif dan pemberdayaan pekerja,

f. Rekan kerja dan bawahan dinyatakan mengetahui lebih banyak tentang kekuatan dan keterbatasan manajer daripada pemimpin tertinggi.

Umpan Balik yang baik Kreitner dan Kinicki (2001) Umpan balik yang baik antara lain:

a. Menghubungkan umpan balik pada tujuan kinerja yang ada dan harapan yang jelas,

b. Memberikan umpan balik secara spesifik,

c. Menghubungkan umpan balik pada bidang yang menjadi hasil utama,

d. Memberikan umpan balik sesegera mungkin,

\section{Reinforcement}

Teori penguatan atau reinforcement theory of motivation dikemukakan oleh B. F. Skinner (1904-1990) dan rekanrekannya. Pandangan mereka menyatakan bahwa perilaku individu merupakan fungsi dari konsekuensikonsekuensinya (rangsangan-respons-konsekuensi). Teori ini didasarkan atas semacam hukum pengaruh dimana tingkah laku dengan konsekuensi positif cenderung untuk diulang, sementara tingkah laku dengan konsekuensi 
negatif cenderung untuk tidak diulang. Teori ini berfokus sepenuhnya pada apa yang terjadi pada seorang individu ketika ia bertindak. Teori ini adalah alat yang kuat untuk menganalisis mekanisme pengendalian untuk perilaku individu. Namun, tidak fokus pada penyebab perilaku individu.

Menurut Skinner, lingkungan eksternal organisasi harus dirancang secara efektif dan positif sehingga dapat memotivasi karyawan. Model penguatan Skinner adalah interval (tetap atau variabel) dan rasio (tetap atau variabel).

1. Penguatan terus menerus

Pemberian secara konstan penguatan terhadap tindakan, dimana setiap kali tindakan tertentu dilakukan diberikan terhadap subjek secara langsung dan selalu menerima penguatan. Metode ini tidak praktis untuk digunakan, dan perilaku diperkuat rentan terhadap kepunahan.

2. Interval (fixed / variabel) penguatan tetap

Penguatan mengikuti respon pertama setelah durasi yang ditetapkan. Variabel-waktu yang harus dilalui sebelum respon menghasilkan penguatan tidak diatur, tetapi bervariasi di sekitar nilai rata-rata.

3. Rasio (tetap atau variabel) penguatan tetap - sejumlah tanggapan harus terjadi sebelum ada penguatan. Variabel-jumlah tanggapan sebelum penguatan disampaikan berbeda dari yang terakhir, namun memiliki nilai rata-rata.

Menurut management study guide, manajer menggunakan metode berikut untuk mengendalikan perilaku karyawan:

1. Penguatan Positif 
Ini berarti ada pemberian tanggapan positif ketika seorang individu menunjukkan perilaku positif yang dibutuhkan. Misalnya memuji karyawan untuk datang lebih awal. Ini akan meningkatkan kemungkinan perilaku yang akan terjadi lagi. Reward adalah positif untuk memperkuat, tapi belum tentu demikian, jika dan hanya jika perilaku karyawan membaik, hadiah dapat dikatakan sebagai dorongan yang positif. Penguatan positif merangsang terjadinya perilaku.

2. Penguatan Negatif

Ini berarti menghargai karyawan dengan menghapus konsekuensi negatif/tidak diinginkan. Baik penguatan positif dan negatif dapat digunakan untuk meningkatkan perilaku yang diinginkan/diperlukan.

3. Hukuman

Ini berarti menghapus konsekuensi positif sehingga dapat menurunkan kemungkinan mengulangi perilaku yang tidak diinginkan di masa depan. Dengan kata lain, hukuman berarti menerapkan konsekuensi yang tidak diinginkan untuk menampilkan perilaku yang tidak diinginkan. Misalnya - Menangguhkan seorang karyawan untuk melanggar aturan organisasi. Hukuman bisa disamakan oleh penguatan positif dari sumber alternatif.

4. Kepunahan

Kepunahan berarti menurunkan kemungkinan perilaku yang tidak diinginkan dengan menghilangkan hadiah untuk perilaku seperti itu.

5. Implikasi Teori

Mirip dengan teori keseimbangan yang membangun kesadaran yang lebih luas terhadap dimensi penilaian 
masing-masing individu sebagai manifestasi keadilan, teori ini juga memandang bahwa penghargaan terhadap karyawan tidak bisa dipukul rata bahwa manajemen harus menghargai semua karyawan secara bersamaan, melainkan harus memberitahu karyawan apa yang perlu dilakukan dengan benar. Karyawan diberitahukan bagaimana mereka dapat mencapai penguatan positif. Teori Penguatan menjelaskan secara rinci bagaimana seseorang belajar berperilaku.

D. Penghargaan

a. Pengertian Penghargaan (reaward)

Penghargaan adalah ganjaran yang diberika n untuk memotivasi para karyawan agar produktivitasnya tinggi (Tohardi, 200 2). Penghargaan adalah insentif yang mengaitkan bayaran atas dasar untuk dapat meningkatkan

produktivitas para karyawan guna mencapai keung gulan yang kompetitif (Henri Simamora, 2004). Penghargaan adalah reward dalam bentuk uang yang diberikan

kepada mereka yang dapat bekerja melampaui stan dar yang telah ditentukan.

(Mahmudi, 2005). Schuster (1985), Byras da n Rue (1997) mendefenisikan penghargaan sebagai berikut : 
a. Penghargaan Intrinsik

Penghargaan intrinsik berisi pengharga an yang berasal dari respon individu terhadap pekerjaan itu sendiri, yaitu berasal dari transaksi antara

seorang individu dengan tugasnya tanpa ikut $s$ ertanya (campur tangan) pihak ketiga. Penghargaan intrinsik ditentukan oleh individu dalam interaksinya dengan pekerjaannya. Contoh, pe nghargaan intrinsik dapat berupa rasa tanggung jawab, rasa tertantang, rasa unggul, rasa mengontrol, rasa berpartisipasi, dan sebagainya. Manajeme $\mathrm{n}$ harus merancang pekerjaan sedemikian rupa sehingga pengharg aan intrinsik dapat dicapai oleh karyawan yang memenuhinya.

b. Penghargaan Ekstrinsik

Penghargaan ekstrinsik adalah kompensa si yang secara langsung disampaikan dan dikontrol oleh organisasi (pihak ketiga) serta bersifat lebih kasat mata (mudah dilihat). Sistem penghargaan ekstrinsik mengacu pada semua penghargaan di luar pekerjaan itu sendiri.

Dengan demikian, sistem penghargaan ekstrinsik mencakup baik $p$ enghargaan finansial maupun nonfinansial yang diberikan oleh organisasi dalam $u$ sahanya untuk merespon kinerja karyawan, baik secara kualitas maupun kuantitas. 
b. Tujuan Penghargaan

Pada prinsipnya penghargaan merupakan program wajib perusahaan yang menginginkan karyawan berprestasi dan mampu $b$ ekerja melebihi target

perusahaan (Mahmudi, 2005). Maka jelas pengharg aan organisasional adalah semua yang dihargai dan diinginkan sumber daya manusia yang mampu dan mau

diberikan perusahaan sebagai ganti atas kontribusi yang diberikan sumber daya manusia tersebut. Didalamnya terbagi lagi menjadi berbagai penghargaan finansial dan non-finanasial.

Penghargaan dapat menjembatani gap anta ra tujuan perusahaan dengan harapan dan aspirasi individual (Sedamaryanti, 2001). Sedamaryanti (2001) juga menjelaskan bahwa penghargaan berfu ngsi

sebagai motivasi untuk mengulangi perilaku yang $d$ isetujui secara sosial, juga untuk memperkuat perilaku yang disetujui secara sosial. Maksud dan tujuan

dari

penghargaan adalah agar karyawan menjadi lebih $\mathrm{g}$ iat lagi usahanya untuk

memperbaiki atau mempertinggi prestasi yang tela h dicapainya. Jadi dalam sisi

yang lebih luas, penghargaan dirancang agar mam pu menarik perhatian, mempertahankan dan mendorong karyawan agar bekerja lebih produktif, di mana penghargaan harus mencerminkan win-win 
result, bagi karyawan dan perusahaan. Secara luas penghargaan diciptakan untuk menarik, menahan, dan memotivasi kinerja karyawan.

Namun tujuan yang lebih penting didalamn ya adalah keadilan atas persamaan yang bisa dicapai dengan setidaknya tiga dimensi berikut:

a. Kesamaan Internal: berdasarkan harga dari apa yang diberikan karyawan bagi perusahaan.

b. Kesamaan Eksternal: disesuaikan dengan pemb ayaran raya-rata perusahaan lainnya.

c. Kesamaan Individual: pembayaran yang adil se sama individu yang melakukan pekerjaan yang sama atau serupa.

c. Faktor-faktor yang Mempengaruhi Penghargaan

Terdapat 4 faktor yang harus dijadikan das ar dalam

mempertimbangkan kebijakan penghargaan (reward) menurut Nawawi (1999),

yaitu Internal Consistency (konsistensi internal), Ext ernal Compentitiveness

(persaingan/ kompetensi eksternal), Employee cont ributions (kontribusi karyawan), dan Administration (administrasi).

d. Komponen Penghargaan

Komponen-komponen penghargaan tersebut dapat dijelaskan sebagai berikut:

1. Gaji, adalah balas jasa yang dibayar secara periodik kepada karyawan tetap serta mempunyai jaminan

yang 
(Hasibuan, 2003). Maksudnya gaji akan tetap di bayarkan karyawan

walaupun pekerja tersebut tidak masuk kerja.

2. Bonus,

Ruky (2001) mendefinisikan bonus sebagai pem berian pendapatan tambahan bagi karyawan/pekerja yang hanya diberikan setahun sekali bila syaratsyarat tertentu dipenuhi. Pertama, bonus hanya dapat diberikan bila perusahaan memperoleh laba selama tahun fiskal yang telah berlalu. Karena bonus biasanya diambil dari keuntungan bersih yang diperoleh perusahaan. Kedua, bonus tidak diberikan secara merata kep ada semua karyawan. Artinya, besarnya bonus harus dikaitkan dengan prestasi kerja individu.

3. Insentif, adalah imbalan langsung yang diberikan kepada karyawan

karena kinerjanya melebihi standar yang ditentu kan (Panggabean, 2002).

Pada prakteknya, insentif adalah alat untuk me mbangun, memelihara dan memperkuat harapan karyawan, sehingga dengan demikian dapat kual itas kerja dari suatu keadaan tertentu menuju arah maksimal.

4. Promosi, dapat terjadi apabila seorang karyawan dipindahkan dari

satu pekerjaan ke pekerjaan lain yang lebih ting gi dalam pembayaran, tanggung jawab dan atau level (Indrawan, 2005 
). Promosi memberikan

peran penting bagi setiap karyawan, bahkan $m$ enjadi idaman yang selalu dinantinantikan. Dengan promosi berarti ada kepercay aan dan pengakuan mengenai kemampuan serta kecakapan karyawan yang bersangkutan untuk menduduki suatu jabatan yang lebih tinggi. Dengan demikian, promosi akan memberikan status sosial, wewenang (authority), tanggung jawab (responsibility) serta penghasilan (outcomes) ya ng semakin besar bagi karyawan.

e. Prinsip-prinsip Pemberian Penghargaan

Lia Kanjeng Ais (2010) menjelaskan prinsipprinsip pemberian penghargaan sebagai berikut :

1. Penilaian didasarkan pada "perilaku" bukan "pelaku".

2. Pemberian penghargaan atau hadiah harus ada batasnya.

3. Pemberian penghargaan dapat berupa perhatian lebih atau perhatian intensif.

4. Pemberian penghargaan distandarkan pada $\mathrm{pr}$ oses, bukan hasil.

f. Hukuman (punishment)

1. Pengertian Hukuman (punishment)

Hukuman (punishment) adalah sebuah cara untuk mengarahkan sebuah tingkah laku agar sesuai dengan tingkah laku yang berlaku secara 
umum. Dalam hal ini, hukuman diberikan ketika sebuah tingkah laku yang tidak diharapkan ditampilkan oleh orang yang bersangkutan atau orang yang bersangkutan tidak memberikan respon atau tidak menampilkan sebuah tingkah laku yang diharapkan.

2. Fungsi Hukuman

Ada tiga fungsi penting dari hukuman yang berperan besar bagi pembentukan tingkah laku yang diharapkan:

a. Membatasi perilaku. Hukuman menghalangi terjadinya pengulangan tingkah laku yang tidak diharapkan.

b. Bersifat mendidik.

c. Memperkuat motivasi untuk menghindarkan diri dari tingkah laku yang tidak diharapkan.

g. Masalah yang muncul dalam Perusahaan mengenai Reward dan Punishment.

Dalam lingkungan perusahaan aturan yang berlaku pada setiap elemen yang berada dalam suatu perusahaan atau organisasi memiliki tanggung jawab yang sama atas tugasnya masing-masing. Seperti halnya pegawai dan manajer, pegawai bertanggung jawab atas tugasnya sebagai oprasional dalam suatu perusahaan. Dan manajer bertanggung jawab sebagai pengendali operasional, dengan tingkat propesional tertentu yang telah memiliki tugasnya masing-masing, tanpa harus mencampuri tugas dari pegawai sebagai operasional. Dengan hal itu berdirinya suatu 
perusahaan tidak lepas dari pemikiran para pendiri perusahaan yang telah mengetahui kekurangan dan kelebihan perusahaannya, pemimpin perusahaan harus bisa memanage pegawainya dengan aturan yang diberlakukan. Karenanya pemimpin perusahaan harus memiliki konsep untuk memberikan penghargaan maupun hukuman kepada anggotanya. Dimana penghargaan tersebut dimaksudkan untuk memberikan motivasi kepada pegawainya dengan sama rata, dan hukuman diberikan dengan maksud untuk memberikan perhatian kepada pegawainya agar bekerja secara aktif professional. Namun pada prakteknya, para pemimpin perusahaan tidak terlalu mengertikan pegawainya bekerja sesuai waktu dan komposisinya. Kasus seperti inilah yang sekarang sering terjadi dalam lingkungan perusahaan, yang membuat anggota perusahaan tersebut mengambil resiko keluar dari aturan perusahaan tanpa memikirkan hukuman yang akan menimpanya.

h. Tata cara mengurangi penyalahgunaan Reward dan Punishment

Ada beberapa cara yang dapat mengurangi tingkat kesalahan pegawai, maupun pemimpin dalam system pemberian penghargaan dan hukuman. Cara mengurangi tingkat kesalahan pegawai yang dapat dilakukan oleh pemimpin perusahaan:

1. Pemimpin perusahaan memberikan peringatan lisan kepada pegawainya yang melakukan kesalahan. 
2. Teguran keras diberikan jika pegawainya tetap melakukan kesalahan yang sama.

3. Memberikan peringatan tertulis

4. Pengurangan tanggung jawab

5. Pergantian posisi jabatan

6. Penurunan pangkat

7. Penundaan peningkatan gaji/promosi jabatan

8. Serta pemberhentian kerja. 


\section{BAB 5}

\section{Motivasi}

A. Komponen Pembentuk Motivasi

1. Pengertian Motivasi

Motivasi adalah keseluruhan proses pemberian motivasi bekerja kepada bawahan sedemikian rupa sehingga mereka mau bekerja dengan ikhlas demi tercapainya tujuan organisasi dengan efisien dan ekonomis (Siagian, 1994:128). Menurut George $R$. Terry, motivasi adalah keinginan yang terdapat pada seorang individu yang merangsangnya melakukan tindakan. Selanjutnya menurut Greenberg dan Baron (1993:114) adalah suatu proses yang mendorong, mengarahkan dan memelihara perilaku manusia kearah pencapaian tujuan.

Berdasarkan beberapa pengertian diatas maka dapat diambil kesimpulan bahwa motivasi adalah suatu proses seorang individu dalam berperilaku sedemikian rupa sehingga mau bekerja atau bertindak demi tercapainya tujuan organisasi.

2. Pentingnya Motivasi dalam Organisasi

Motivasi organisasi adalah suatu keahlian, dalam mengarahkan pegawai dan organisasi agar mau bekerja. Berdasarkan tujuan yang ingin dicapai, manusia akan termotivasi oleh kebutuhan yang dimilikinya. Pendapat ini sejalan dengan Robin yang mengemukakan bahwa motivasi organisasi adalah kesediaan untuk mengeluarkan tingkat upaya yang tinggi untuk tujuan organisasi yang di kondisikan oleh 
kemampuan upaya itu dalam memenuhi beberapa kebutuhan individual.1[3] Motivasi ini dapat pula dikatakan sebagai energi untuk membangkitkan dorongan dalam diri. Terkait dengan motivasi organisasi lima fungsi utama manajemen adalah planning, organizing, staffing, leading, dan controlling, Pada pelaksanaanya, setelah rencana dibuat, organisasi dibentuk, dan disusun personalianya, langkah berikutnya adalah menugaskan atau mengarahkan anggota menuju ke arah tujuan yang telah di tentukan. Fungsi pengarahan ini secara sederhana membuat anggota melakukan sesuatu sesuai dengan apa yang diinginkan dan harus mereka lakukan. Memotivasi organisasi merupakan kegiatan kepemimpinan yang termasuk di dalam fungsi ini. Kemampuan ketua organisasi untuk memotivasi anggotanya akan sangat menentukan efektifitas ketua. Ketua harus dapat memotivasi para anggotanya agar pelaksanaan kegiatan dan kepuasan kerja mereka meningkat. Jika ketua membiarkan anggotanya berjalan tanpa motivasi, maka bisa di pastikan kinerja organisasi yang memburuk, menemukan kegagalan program kerja bahkan terancam bubar. Menurut Atkinson, suatu organisme (dalam diri manusia dan hewan) yang dimotvasi akan terjuan ke dalam suatu aktivitas secara lebih giat dan lebih efisien daripada yang tidak di motivasi. Motivasi organisasi sebisa mungkin memahami masalah anggotanya, sehingga bisa 
memecahkan masalah secara formal maupun informal . Baik secara organisatoris maupun pendekatan secara personal. Sebagai pimpinan organisasi , sebisa mungkin memahami masalah anggotanya sehingga bisa memecahkan masalah secara bersama. Peran evaluasi sangat penting dalam hal ini. Sehingga tidak ada anggota yang merasa terpaksa menjalankan roda organisasi. Apalagi jika organisasi bersifat sukarela, alias tidak ada upah kerja untuk anggotanya.

3. Proses Timbulnya Motivasi dalam Organisasi

Proses motivasi terdiri beberapa tahapan proses (Indriyo Gitosudarmo, 1997) sebagai berikut:

a. Apabila dalam diri manusia itu timbul suatu kebutuhan tertentu dan kebutuhan tersebut belum terpenuhi maka akan menyebabkan lahirnya dorongan untuk berusaha melakukan kegiatan.

b. Apabila kebutuhan belum terpenuhi maka seseorang kemudian akan mencari jalan bagaimana caranya untuk memenuhi keinginannya

c. Untuk mencapai tujuan prestasi yang diharapkan maka seseorang harus didukung oleh kemampuan, keterampilan maupun pengalaman dalam memenuhi segala kebutuhannya.

d. Melakukan evaluasi prestasi secara formal tentang keberhasilan dalam mencapai tujuan yang dilakukan secara bertahap

e. Seseorang akan bekerja lebih baik apabila mereka merasa bahwa apa yang mereka lakukan dihargai dan diberikan suatu imbalan atau ganjaran 
f. Dari gaji atau imbalan yang diterima kemudian seseorang tersebut dapat mempertimbangkan seberapa besar kebutuhan yang bisa terpenuhi dari gaji atau imbalan yang mereka terima.

4. Faktor-Faktor yang Mempengaruhi Motivasi

Motivasi sebagai proses psikologis dalam diri seseorang akan dipengaruhi oleh beberapa faktor. Faktor-faktor tersebut dapat dibedakan atas faktor intern dan ekstern yang berasal dari karyawan.

1. Faktor Internal

Faktor Intern yang dapat mempengaruhi pemberian motivasi pada seseorang antara lain:

a. Keinginan untuk dapat hidup;

b. Keinginan untuk dapat memiliki;

c. Keinginan untuk memperoleh penghargaan;

d. Keinginan untuk memperoleh pengakuan;

e. Keinginan untuk berkuasa.

2. Faktor Eksternal

Faktor ekstern juga tidak kalah peranannya dalam melemahkan motivasi kerja seseorang. Faktor-faktor ekstern itu adalah:

a. Kondisi lingkungan kerja;

b. Kompensasi yang memadai;

c. Supervise yang baik;

d. Adanya jaminan pekerjaan;

e. Status dan tanggung jawab;

f. Peraturan yang fleksibel. 
B. Teori Motivasi

Teori motivasi dikelompokkan menjadi dua kelompok, yaitu teori kepuasan (content theory) dan teori proses (process theory).

1. Teori Motivasi Kepuasan (Content Theory)

Pada dasarnya Teori ini lebih didekatkan pada factor - factor kebutuhan dan kepuasan individu yang menyebabkannya bertindak dan berperilaku dengan cara tertentu.2[3] Pada teori kepuasan ini didukung juga oleh para pakar diantaranya:
a. Teori Hirarki Kebutuhan (A. Maslow)
b. Teori Tiga Motif Sosial (D. McClelland)
c. Teori Dua Faktor (Frederick Herzberg)
d. Teori E-R-G (Clayton Alderfer)

2. Teori Motivasi proses (process theory)

Teori ini berusaha agar setiap pekerja giat sesuai dengan harapan organisasi perusahaan. Daya penggeraknya adalah harapan akan diperoleh si pekerja. Dalam hal ini teori motivasi proses yang dikenal seperti :

a. Teori Harapan (Expectancy Theory), komponennya adalah: Harapan, Nilai (Value), dan Pertautan (Instrumentality). Tokoh dalam teori ini adalah Victor Vroom.

b. Teori Keadilan (Equity Theory), hal ini didasarkan tindakan keadilan diseluruh lapisan serta obyektif di 
dalam lingkungan perusahaannya. Tokoh dalam teori ini adalah S. Adams.

c. Teori Pengukuhan (Reinfocement Theory), hal ini didasarkan pada hubungan sebab-akibat dari pelaku dengan pemberian kompensasi. Tokoh dalam teori ini adalah B.F. Skinner. 


\section{BAB 6}

\section{Kelompok dan Tim}

\section{A. Konsep Dan Perbedaan Kelompok Dan Tim}

\section{Mendefinisikan dan Mengklasifikasikan Kelompok}

Kelompok (group) menurut Robbins (1996) mendefinisikan kelompok sebagai dua individu atau lebih, yang berinteraksi dan saling bergantung, yang saling bergabung untuk mencapai sasaran-sasaran tertentu. Kelompok-kelompok di dalam organisasi secara sengaja direncanakan atau sengaja dibiarkan terbentuk oleh manajemen selaku bagian dari struktur organisasi formal. Kendati begitu, kelompok juga kerap muncul melalui proses sosial dan organisasi informal. Organisasi informal muncul lewat interaksi antar pekerja di dalam organisasi dan perkembangan kelompok jika interaksi tersebut berhubungan dengan norma perilaku mereka sendiri, kendati tidak digariskan lewat struktur formal organisasi. Dengan demikian, terdapat perbedaan antara kelompok formal dan informal.

\section{a. Kelompok Formal}

Kelompok ini dibangun selaku akibat dari pola struktur organisasi dan pembagian kerja yang ditandai untuk menegakkan tugas - tugas. Kebutuhan dan proses organisasi menimbulkan formulasi tipe - tipe kelompok yang berbedabeda. Khususnya ada dua tipe kelompok formal, di antaranya : 


\section{Kelompok Komando (Command Group)}

Kelompok komando ditentukan oleh bagan organisasi. Kelompok terdiri dari bawahan yang melapor langsung kepada seorang supervisor tertentu. Hubungan wewenang antara manajer departemen dengan supervisor, atau antara seorang perawat senior dan bawahannya, merupakan kelompok komado.

\section{Kelompok Tugas (Task Group)}

Kelompok tugas terdiri dari para karyawan yang bekerja - sama untuk menyelesaikan suatu tugas atau proyek tertentu. Misalnya, kegiatan para karyawan administrasi dalam perusahaan asuransi pada waktu orang mengajukan tuntutan kecelakaan, merupakan tugas yang harus dilaksanakan.

\section{b. Kelompok Informal}

\section{Kelompok}

pengelompokan secara wajar dari orang - orang dalam situasi kerja untuk memenuhi kebutuhan sosial. Dengan perkataan lain, kelompok informal tidak muncul karena dibentuk dengan sengaja, tetapi muncul secara wajar. 
Orang mengenal dua macam kelompok informal khusus diantaranya:

\section{Kelompok Kepentingan (Interest Group)}

Orang yang mungkin tidak merupakan anggota dari kelompok komando atau kelompok tugas yang sama, mungkin bergabung untuk mencapai sesuatu sasaran bersama. Para karyawan yang bersama - sama bergabung dalam kelompok untuk membentuk front yang terpadu menghadapi manajemen untuk mendapatkan manfaat yang lebih banyak dan pelayan wanita yang mengumpulkan uang persen mereka merupakan contoh dari kelompok kepentingan. Perlu diketahui juga tujuan kelompok semacam itu tidak berhubungan dengan tujuan organisasi, tetapi tujuan itu bersifat khusus bagi tiap - tiap kelompok.

\section{Kelompok Persahabatan (Friendship Group)}

Banyak kelompok dibentuk karena para anggotanya mempunyai sesuatu kesamaan, misalnya usia, kepercayaan politis, atau latar belakang etnis. Kelompok persahabatan ini seringkali melebarkan interaksi dan komunikasi mereka sampai pada kegiatan diluar pekerjaan.

Jika Pola gabungan karyawan dicatat, maka akan segera menjadi jelas bahwa mereka termasuk dalam berbagai macam kelompok yang sering bersamaan. Maka diadakan 
perbedaan diantara dua klasifikassi kelompok yang luar: kelompok formal dan informal. Perbedaan utama antara keduanya adalah bahwa kelompok formal ( kelompok komando dan kelompok tugas) dibentuk oleh organisasi formal dan merupakan alat untuk mencapai tujuan, sedangkan kelompok informal (kelompok kepentingan dan kelompok persahabatan) adalah penting untuk keperluan mereka sendiri ( artinya, mereka memenuhi kebutuhan pokok akan berkelompok).

\section{Struktur dan Perilaku Dalam Kelompok}

Struktur suatu kelompok dapat terlihat dari pola hubungan yang berlaku tetap antara anggota kelompok yang bersangkutan. Pola hubungan ini menimbulkan kecenderungan pada tiap anggota untuk menempatkan diri mereka masing-masing pada tempat yang menurut mereka merupakan tempat yang tepat untuk mereka.

\section{Hubungan Antar-Status}

Susunan status atau urutan sosial dapat berkembang karena berbagai sebab. Namun secara umum dapat dikatakan bahwa status bergantung pada berapa besar seseorang memberikan sumbangannya bagi tercapainya tujuan. Seseorang yang merasa mempunyai 'jasa' terbesar cenderung berusaha mendapatkan status yang tinggi. Susunan status dalam suatu kelompok, dan juga dalam suatu organisasi, selalu tampil dalam dua wujud, yaitu berupa status formal dan status sosial. 


\section{Status dan Pola Interaksi Manusia}

Fisek dan Ofshe mengemukakan bahwa tingkah laku atau cara berinteraksi suatu kelompok sering sekali memberikan suatu gambaran mengenai struktur status dalam kelompok tersebut. Hasil penelitian menunjukkan bahwa seseorang yang banyak mendapatkan interaksi dari yang lain biasanya merupakan pimpinan kelompok.

\section{Konsep Tentang Tim Kerja}

a. Pengertian Tim Kerja

Tim kerja adalah kelompok yang usahausaha individualnya menghasilkan kinerja lebih tinggi daripada jumlah masukan individual (Stephen, Timothy2008:406). Hal ini memiliki pengertian bahwa kinerja yang dicapai oleh sebuah tim lebih baik daripada kinerja per individu disuatu organsasi.

\section{b. Perbedaan Tim Kerja dengan kelompok kerja}

Tim adalah suatu unit yang terdiri atas dua orang atau lebih yang berinteraksi dan mengkoordinasi kerja mereka untuk tujuan tertentu. Definisi ini memiliki tiga komponen. Pertama, dibutuhkan dua orang atau lebih. Kedua, orang - orang dalam sebuah tim memiliki interaksi regular. Ketiga, orang - orang dalam sebuah tim memiliki tujuan kinerja yang sama. Kelompok tidak sama dengan tim. Kelompok didefinisikan sebagai dua individu atau lebih, yang berinteraksi dan saling bergantung, yang bergabung bersamasama untuk mencapai sasaran. Suatu kelompok 
kerja adalah kelompok yang terutama berinteraksi untuk berbagi informasi dan mengambil keputusan untuk membantu tiap anggota berkinerja dalam bidang tanggung jawabnya. Kelompok kerja tidak perlu untuk melakukan kerja kolektif yang menuntut upaya gabungan. Jadi kinerja mereka sekedar jumlah kinerja sumbangan individual dari tiap anggota kelompok. Tidak ada sinergi positif yang akan menciptakan suatu tingkat keseluruhan kinerja yang lebih besar daripada jumlah masukan.

Kerja tim ialah kerja berkelompok dengan keterampilan yang saling melengkapi untuk mencapai tujuan bersama secara efektif dan efisien. Kerja tim dapat memberikan manfaat antara lain:

1. Pekerjaan menjadi lebih ringan karena dilakukan bersama

2. Dapat menimbulkan semangat kebersamaan.

3. Lebih efektif dan efisien dibandingkan dikerjakan sendiri-sendiri.

4. Kinerja organisasi lebih meningkat.

\section{c. Tipe/Jenis-jenis Tim}

Tim dapat diklasifisikan berdasarkan sasarannya. Bentuk yang paling umum digunakan dalam organisasi atau perusahaan adalah :

\section{Tim Pemecah Masalah}


Tim ini terdiri dari 5 sampai 12 karyawan jam-jaman dari suatu departemen yang bertemu selama beberapa jam tiap pekan untuk membahas perbaikan kualitas, efisiensi dan lingkungan kerja. Dalam tim pemecah masalah, anggota bernagi gagasan atau menawarkan saran mengenai bagaimana proses dan metode kerja dapat diperbaiki. Tetapi jarang tim-tim diberi wewenang untuk melaksanakan secara sepihak setiap tindakan mereka yang disarankan.

\section{Tim Kerja Pengelola Diri}

Tim kerja pengelola diri adalah kelompok karyawan (biasanya 10 sampai 15 orang) yang memikul tanggung jawab dari mantan penyelia mereka. Tim ini mencakup kerja tentang perencanaan dan penjadwalan kerja, kontrol kolektif atas langkah kerja, membuat keputusan operasi dan mengambil tindakan atas permasalahan. Tim ini bahkan memilih anggotanya sendiri dan menyuruh anggota itu untuk saling menilai kinerja.

\section{Tim Lintas Fungsional.}

Tim lintas fungsional adalah tenaga kerja dari tingkat hirarki yang sama, tetapi dari tempat pekerjaan yang berbeda. Tim 
lintas fungsional merupakan cara efektif yang memungkinkan orang-orang dari aneka bidang dalam suatu organisasi (atau bahkan antar organisasi) untuk bertukar informasi, mengembangkan gagasan baru dan memecahkan masalah, serta mengkoordinasikan proyek yang rumit.

\section{Tim Virtual}

Tim Virtual adalah tim yang menggunakan teknologi komputer untuk mengikat secara fisik secara bersama membagi anggota untuk mencapai tujuan bersama. Mereka mengizinkan orang untuk bergabung secara langsung dengan menggunakan komunikasi langsung diantaranya seperti lokasi jaringan kerja, video konfrensi dan e-mail. Tim virtual terdiri atas anggota - anggota yang tersebar secara geografis dan organisasional yang terikat terutama oleh kemajuan teknologi informasi dan telekomunikasi. Tim virtual sering meliputi para pekerja lepas, anggota organisasi rekanan, pelanggan, pemasok, konsultan, atau pihak - pihak luar lainnya. Salah satu keuntungan utama tim virtual adalah kemampuan untuk dengan cepat mengumpulkan kelompok orang yang paling tepat untuk menyelesaikan proyek yang kompleks, memecahkan masalah tertentu, 
atau mengekploitasi peluang strategis tertentu.

\section{d. Membentuk Tim Kerja yang Efektif}

Efektifitas tim kerja didasarkan pada dua hasil, hasil produktif dan kepuasan pribadi. Kepuasan berkenaan dengan kemampuan tim untuk memenuhi kebutuhan pribadi para anggotanya dan kemudian mempertahankan keanggotaan serta komitmen mereka. Hasil produktif berkenaan dengan kualitas dan kuantitas hasil kerja seperti yang didefinisikan oleh tujuan - tujuan tim. Faktor - faktor yang mempengaruhi efektifitas tim yaitu konteks organisasional, struktur, strategi, lingkungan budaya, dan system penghargaan. Karakter tim yang penting adalah jenis, struktur, dan komposisi tim. Karakteristik - karakteristik tim ini mempengaruhi proses internal tim, yang kemudian mempengaruhi hasil dan kepuasan. Para pemimpin harus memahami dan mengatur tingkat - tingkat perkembangan, kekompakan, norma - norma, dan konflik supaya dapat membangun tim yang efektif. Ciri-ciri tim yang efektif :

\section{Tujuan yang sama}

Jika semua anggota tim mendayung ke arah yang sama, pasti kapal yang didayung akan lebih cepat sampai ke tempat tujuan, dari pada jika ada anggota tim yang 
mendayung ke arah yang berbeda, berlawanan, ataupun tidak mendayung sama sekali karena bingung ke arah mana harus mendayung. Jadi, pastikan bahwa tim memiliki tujuan dan semua anggota tim Anda tahu benar tujuan yang hendak dicapai bersama, sehingga mereka yakin ke arah mana harus mendayung.

a. Antusiasme yang tinggi.

b. Peran dan tanggung jawab yang jelas.

c. Komunikasi yang efektif.

\section{Resolusi Konflik.}

Peace is not the absence of conflict, but the presence of justice. Ini merupakan pendapat Martin Luther King. Rasanya hal ini berlaku pula pada pencapaian sebuah tujuan. Dalam mencapai tujuan mungkin saja ada konflik yang harus dihadapi. Tetapi konflik ini tidak harus menjadi sumber kehancuran tim. Sebaliknya, konflik ini yang dapat dikelola dengan baik bisa dijadikan senjata ampuh untuk melihat satu masalah dari berbagai aspek yang berbeda sehingga bisa diperoleh cara baru, inovasi baru, ataupun perubahan yang memang diperlukan untuk melaju lebih cepat ke arah tujuan. Jika terjadi konflik, jangan didiamkan ataupun dihindari. Konflik yang tidak ditangani secara langsung akan menjadi seperti kanker yang menggerogoti 
semangat tim. Jadi, konflik yang ada perlu segera dikendalikan.

\section{Shared power.}

Jika ada anggota tim yang terlalu dominan, sehingga segala sesuatu dilakukan sendiri, atau sebaliknya, jika ada anggota tim yang terlalu banyak menganggur, maka pasti ada ketidak beresan dalam tim yang lambat laun akan membuat tim menjadi tidak efektif. Jadi, tiap anggota tim perlu diberikan kesempatan untuk menjadi "pemimpin", menunjukkan "kekuasaannya" di bidang yang menjadi keahlian dan tanggung jawab mereka masing-masing. Sehingga mereka merasa ikut bertanggung jawab untuk kesuksesan tercapainya tujuan bersama.

\section{e. Rancangan pekerjaan}

Keefektifan tim membutuhkan kerjasama dan menempatkan tanggung jawab bersama untuk melaksanakan tugas penting. Kelompok rancangan kerja meliputi variabel-variabel seperti kebebasan dan otonomi, keuntungan pada kegunaan keahlian berbeda dan talenta, kemampuan untuk menyelesaikan dan mengidentifikasi semua tugas atau produk, dan bekerja dalam tugas atau proyek yang berpengaruh secara substansial dengan yang lain. Rancangan kerja ini menggambarkan motivasi karena meningkatkan rasa tanggung jawab 
anggota dan pemilik pada pekerjaan dan karena membuat pekerjaan lebih menarik untuk dikerjakan.

\section{f. Komposisi}

Kategori ini memasukkan variabel yang terkait bagimana tim dapat dibentuk menjadi staf. Komposisi tim yang efektif terdiri dari :

1. Kemampuan anggota

Untuk bekerja dengan efektif, suatu tim menuntut tiga tipe keterampilan yang berbeda. Pertama, tim perlu orang-orang dengan keahlian teknis. Kedua, perlu orang dengan keterampilan pemecah masalah dan pengambilan keputusan agar mampu mengidentifikasi masalah, membangkitkan alternatif, mengevaluasi alternatif, dan membuat pilihan yang kompeten. Ketiga, tim memerlukan orang dengan keterampilan mendengarkan dengan baik, umpan balik, penyelesaian konflik, dan keterampilan antar pribadi lainnya.

2. Personalitas

Personalitas mempengaruhi individu dalam perilaku. Macam-macam karakter personal dalam tim akan mempengaruhi kinerja tim secara keseluruhan.

3. Mengalokasikan peran dan menggalakkan keanekaragaman

Tim yang berkinerja tinggi benarbenar mencocokkan orang dengan berbagai 
peran. Terdapat sembilan peran potensial dalam tim yaitu; penghubung, pencipta, promosi, penaksir, pengorganisasi, penghasil, pengontrol, pemelihara, dan penasehat. Tim kerja yang berhasil adalah tim yang memiliki orang-orang untuk mengisi semua peran dan menyeleksi orang-orang untuk bermain dalam peran-peran ini berdasarkan pada keterampilan dan pilihan meraka.

4. Ukuran Tim kerja

Tim kerja terbaik cenderung lebih kecil. Bila anggotanya lebih dari 10 sampai 12 , menjadi sulit bagi mereka untuk menyelesaikan banyak hal. Jadi dalam merancang tim yang efektif, para manajer harus menjaga agar anggotanya berkisar antara 5 sampai 12 orang.

5. Kefleksibelan anggota

Tim menciptakan kefleksibelan individual, memiliki anggota yang dapat menyelesaikan tugas yang lainnya. Ini adalah hal positif bagi tim, karena merupakan perbaikan besar bagi penyesuaian dan membuat kurang percaya bagi anggota tunggal.

6. Pilihan anggota

Tidak semua anggota merupakan pemain tim. berikan pilihan, beberapa pekerja akan menyeleksi secara sendirinya keluar dari parstisipasi tim. kinerja tim yang 
tinggi seperti menggabungkan orang yang senang bekerja sebagai bagian dalam tim.

\section{g. Mengubah individu menjadi pemain tim}

\section{Tantangan}

Penghalang besar dalam menggunakan tim kerja adalah penolakan individual. Sukses seorang karyawan tidak lagi didefinisikan dalam kinerja individu.untuk berkinerja baik sebagai anggota tim, individuindividu harus mampu berkomunikasi secara terbuka dan jujur; menghadapi perbedaanperbedaan dan memecahkan konflik-konflik; serta menghaluskan tujuan pribadi untuk kebaikan tim. Tantangan menciptakan pemain tim akan paling besar jika ; budaya nasional sangat individualistik dan tim itu akan dimasukkan ke dalam suatu organisasi yang mapan yang secara historis menghargai prestasi individual.

\section{Membentuk pemain tim}

Berikut ini beberapa cara yang dapat dilakukan untuk mengubah individu menjadi pemain tim :

a. Seleksi

Beberapa orang telah memiliki keterampilan antar pribadi untuk menjadi pemain tim yang efektif. Ketika mempekerjakan anggota tim, disamping 
keterampilan teknis yang diperlukan untuk mengisi pekerjaan itu, harus dipastikan pula bahwa calon dapat memenuhi peran tim mereka maupun persyaratan teknis. Banyak calon yang melamar pekerjaan tidak mempunyai keterampilan tim. Bila menghadapi calon semacam ini, pada dasarnya para manajer atau pimpinan mempunyai tiga pilihan :

1. Calon dapat menjalani pelatihan untuk membuat mereka menjadi pemain tim.

2. Mentransfer individu itu ke unit lain didalam organisasi tanpa tim.

3. Tidak mempekerjakan calon itu.

b. Pelatihan

Sebagian besar orang yang dibesarkan pada lingkungan yang mementingkan prestasi individual dapat dilatih untuk menjadi pemaian tim. Spesialis pelatihan menjalankan latihanlatihan yang memungkinkan karyawan untuk mengalami kepuasan yang dapat diberikan oleh kerja tim.

c. Ganjaran

Sistem ganjaran perlu diperbaiki untuk mendorong upaya kooperatif bukannya kompetitif. Promosi, kenaikan 
upah dan bentuk-bentuk pengakuan lain hendaknya diberikan kepada individu untuk keefektifan mereka sebagai seorang anggota tim yang kolaboratif.

3. Tim dan keanekaragaman angkatan kerja

Mengelola keanekaragaman pada tim adalah suatu tindakan yang menyeimbangkan. Keanekaragaman memberikan perspektif segar mengenai isu-isu, tetapi hal itu membuat lebih sukar untuk mempersatukan tim dan mencapai kesepakatan.

\section{B. Karakteristik Kelompok}

1. Terdiri dari dua orang atau lebih dalam interaksi sosial baik secara verbal maupun non verbal.

2. Anggota kelompok harus mempunyai pengaruh satu sama lain supaya dapat diakui menjadi anggota suatu kelompok

3. Mempunyai struktur hubungan yang stabil sehingga dapat menjaga anggota kelompok secara bersama dan berfungsi sebagai suatu unit

4. Anggota kelompok adalah orang yang mempunyai tujuan atau minat yang sama. 
5. Individu yang tergabung dalam kelompok, saling mengenal satu sama lain serta dapat membedakan orang-orang yang bukan anggota kelompoknya.

\section{b. Jenis-Jenis Kelompok}

Berdasarkan jumlah anggota, sifat hubungan antaranggota, dan tujuannya, kelompok yang ada dalam masyarakat dapat dibedakan menjadi:

\section{Kelompok primer}

Kelompok primer adalah kelompok yang jumlah anggotanya sedikit, walaupun tidak setiap kelompok yang anggotariya sedikit adalah kelompok primer. Hubungan antaranggota bersifat personal (saling kenal secara pribadi) dan mendalam, diwarnai oleh kerja sama, sering bertatap muka dalam waktu lama, sehingga terbangun keterlibatan perasaan yang dalam.

Tujuan berkelompok adalah membangun hubungan personal itu sendiri. Walaupun kadang terjadi konflik, namun masing-masing anggota kelompok primer menunjukkan perhatian yang tulus terhadap kesejahteraan sesama anggota. Jadi, hubungan dalam kelompok primer bersifat informal, intim/akrab, personal, dan total.

\section{Contoh kelompok primer adalah}

- Keluarga 
- Kelompok teman

- Sepermainan.

\section{Kelompok sekunder}

Kelompok sekunder adalah kelompok yang jumlah anggotanya banyak. Hubungan antaranggota bersifat impersonal (tidak saling kenal secara pribadi), lebih diwarnai oleh kompetisi, jarang bertatap muka dalam waktu lama, sehingga tidak terbangun hubungan yang emosional. Hubungan yang ada lebih bersifat fungsional, artinya orang bukan dilihat dan segi "siapanya" melainkan lebih dilihat dan segi "apa kegunaannya" bagi pencapaian tujuan kelompok. Tujuan berkelompok adalah untuk mencapai tujuan tertentu, sehingga kelompok lebih berperan sebagai sarana bukan tujuan. Hubungan dalam kelompok sekunder bersifat formal, impersonal, parsial, dan dilandaskan pada kemanfaatan kelompok semata.

Contoh kelompok sekunder adalah

- organisasi buruh,

- universitas,

- sekolah,

- dan lain-lain. 
Sementara itu, berdasarkan cara pandang seseorang terhadap berbagai kelompok yang melingkupi hidupnya, kelompok dibedakan menjadi:

\section{a. In-group}

Semua kelompok di mana seseorang merasa menjadi anggotanya dan mengharapkan pengakuan, kesetiaan, dan pertolongan.

b. Out-group

Semua kelompok di mana seseorang merasa bukan sebagai anggotanya dan mungkin akan menunjukkan permusuhan, kompetisi damai, atau sekedar merasa berbeda.

In-group dan out-group terpisahkan dalam hubungan permusuhan. Individu anggota in-group menyebut diri "kami", dan menyebut individu anggota outgroup sebagai "mereka". Permusuhan antara in group dan out group cenderung bersuasana kultural (budaya). Misalnya,antara pendatang dengan penduduk asli, antargeng, sampai permushan yang bernuansa SARA. 


\section{Perbandingan Antara Kelompok Primer dan Sekunder}

\begin{tabular}{|c|c|}
\hline Kelompok Primer & Kelompok Sekunder \\
\hline $\begin{array}{l}\text { - Umumnya kecil } \\
\text { - Relatif memiliki interaksi } \\
\text { jangka panjang } \\
\text { - Memiliki hubungan yang } \\
\text { akrab dan sering ber- } \\
\text { temu } \\
\text { - Memiliki kedalaman hu- } \\
\text { bungan emosi } \\
\text { - Mudah bekerja sama } \\
\text { dan personal }\end{array}$ & $\begin{array}{l}\text { - Biasanya besar } \\
\text { - Interaksinya sebentar } \\
\text { (sama rata) } \\
\text { - Keakraban sosial atau } \\
\text { rasa saling pengertian- } \\
\text { nya kurang } \\
\text { - Hubungannya biasanya } \\
\text { hanya di permukaan } \\
\text { - Lebih formal dan imper- } \\
\text { sonal }\end{array}$ \\
\hline
\end{tabular}

\section{c. Tahap Pembentukan Kelompok}

\section{Model Lima Tahap}

Kelompok biasanya berkembang melalui sebuah urutan terstandar dalam evolusi. Model lima tahap perkembangan kelompok (five - stage group development model) menyebutkan karekteristik tahapan perkembangan kelompok dalam lima tahap yang berbeda, diantaranya:

c. Tahap Pembentukan (forming), memiliki karakteristik besarnya ketidakpastian atas tujuan, struktur, dan kepimimpinan kelompok tersebut. Para anggotanya " menguji kedalaman air " untuk menentukan jenis - jenis perilaku yang dapat diterima. Tahap ini selesai ketika para anggotanya mulai menganggap diri mereka sebagai bagian dari kelompok. 
d. Tahap Timbulnya konflik (storming stage) adalah satu dari konflik intrakelompok. Para anggotanya menerima keberadaan kelompok tersebut, tetapi terdapat penolakan terhadap batasan - batasan yang diterapkan kelompok terhadap setiap individu. Ketika tahap ini selesai, terdapat sebuah hierarki yang relatif jelas atas kepemimpinan dalam kelompok tersebut.

e. Tahap Normalisasi ( norming stage) adalah tahap di mana hubungan yang dekat terbentuk dan kelompok tersebut menunjukkan kekohesifan. Dalam tahap ini terbentuk sebuah rasa yang kuat akan identitas kelompok dan persahabatan. Tahap ini selesai ketika struktur kelompok tersebut menjadi solid dan kelompok telah mengasimilasi serangkaian ekspektasiumum definisi yang benar atas perilaku organisasi.

f. Tahap Berkinerja (performing) adalah tahap di mana struktur telah sepehunya fungsional dan diterima. Energi kelompok telah berpindah dari saling mengenal dan memahami menjadi mengerjakan tugas yang ada.

g. Tahap Pembubaran(adjourning stage). Dalam tahap ini, kelompok tersebut mempersiapkan diri untuk pembubarannya. Kinerja tugas yang tinggi tidak lagi menjadi prioritas tertinggi kelompok. Sebagai gantinya, perhatian diarahkan untuk menyelesaikan aktivitas - aktivitas.

2. Hal-hal mengenai Kelompok: Peran, Norma, Status, Ukuran dan Kekohesifan 


\section{a. Peran}

Istilah ini dimaksudkan sebagai serangkaian pola perilaku yang dikaitkan erat dengan seseorang yang menempati sebuah posisi tertentu dalam sebuah unit sosial. Pemahaman atas perilaku peran akan secara dramatis disederhanakan jika masingmasing dari kita memilih satuperan dan memainkannya secara teratur dan konsisten. Sayangnya, kita diharuskan memainkan sejumlah ragam peran, baik dalam pekerjaan maupun di luar pekerjaan kita.

\section{b. Norma}

Norma adalah standar-standar perilaku yang dapat diterima dalam sebuah kelompok yang dianut oleh para anggota kelompok. Norma memberi tahu apa yang harus dan tidak harus dilakukan di bawah keadaan-keadaan tertentu. Dari sudur seorang individu, norma-norma tersebut memberi tahu apa yang diharapkan dari seorang Anda dalam situasisituasi tertentu. Ketika disetujui dan diterima oleh kelompok, norma berlaku sebagai cara untuk memengaruhi perlaku dari anggota kelompok dengan kontrol eksternal yang minimum. Norma berbeda antar kelompok, komunitas, dan masyarakat, tetapi mereka semua memilikinya.

\section{c. Status}

Status adalah sebuah posisi atau pangkat yang didefinisikan secara sosial yang diberikan kepada kelompok atau anggota kelompok oleh 
orang lain-meresap dalam setiap masyarakat. Meskipun telah ada banyak usaha, kita hanya mendapat sedikit kemajuan menuju sebuah masyarakat tanpa kelas. Bahkan kelompok yang paling kecil akan mengembangkan peran-peran, hak-hak, dan ritual-ritual untuk membedakan para anggotanya. Status adalah faktor penting dalam memahami perilaku manusia karena hal ini adalah sebuah motivator signifikan dan memiliki kensekuensi-konsekuensi perilaku besar ketika individu-individu menerima perbedaan antara apa yang mereka percaya sebagai status dna apa yang dirasakan oleh orang lain.

\section{d. Ukuran}

Apakah ukuran dari sebuah kelompok memengaruhi perilaku kelompok secara keseluruhan? Jawaban atas pertanyaan ini pastinya adalah Ya, tetapi pengaruhnya bergantung pada variabel yang Anda lihat. Sebagai contoh, bukti yang ada mengindikasikan bahwa kelompok yang lebih kecil lebih cepat dalam menyelesaikan tugas daripada kelompok yang lebih besar, dan bahwa individu-individu berkinerja lebih baik dalam kelompok yang lebih kecil. Tetapi, jika kelompok tersebut terlibat dalam pemecahan masalah, kelompok besar secara konsisten mendapat nilai yang lebih baik dibandingkan yang lebih kecil.

Salah satu penemuan paling penting yang berhubungan dengan ukuran sebuah kelompok telah diberi label kemalasan sosial (social loafing). Kemalasan sosial adalah sebuah 
kecenderungan para individu untuk mengeluarkan usaha yang lebih sedikit ketika bekerja secara kolektif daripada ketika bekerja secara individual. Hal tersebut secara langsung bertentangan dengan logika bahwa produktivitas dari sebuah kelompok sebagai keseluruhan setidaknya harus seimbang dengan jumlah produktivitas setiap individu dalam kelompok tersebut.

\section{e. Kekohesifan}

Kelompok-kelompok berbeda dalam kekohesifan mereka, yaitu, tingkat di mana para anggotanya saling tertarik dan termotivasi untuk tinggal dalam kelompok tersebut. Misalnya, beberapa kelompok kerja menjadi kohesif karena para anggotanya telah menghabiskan banyak waktu bersama, atau ukuran kelompok yang kecil memfasilitasi adanya interaksi yang tinggi, atau kelompok tersebut telah mengalami ancamanancaman eksternal yang menjadikan mereka lebih dekat. Kekohesifan penting karena berhubungan dengan produktivitas kelompok.

Berbagai penelitian secara konsisten menunjukkan bahwa hubungan kekohesifan dan produktivitas bergantung pada norma-norma terkait kinerja yang ditetapkan oleh kelompok. Jika norma-norma terkait kinerja tinggi, kelompok kohesif akan lebih produktif dibandingkan dengan kelompok yang kurang kohesif. Namun jika kekohesifan tinggi dan norma kinerja rendah, produktivitas akan rendah. Jika kekohesifan rendah dan norma kinerja tinggi, produktivitas meningkat, 
tetapi lebih sedikit bila dibandingkan pada situasi kekohesifan tinggi/norma tinggi. 


\section{BAB 7}

\section{Mengelola Konflik}

\section{A. Jenis-Jenis Konflik}

Menurut Robbins, Pengertian Konflik adalah suatu proses yang dimulai bila satu pihak merasakan bahwa pihak lain telah memengaruhi secara negatif atau akan segera memengaruhi secara negatif pihak lain.

1. Pengertian Konflik menurut Alabaness adalah kondisi yang dipersepsikan ada di antara pihak-pihak atau lebih merasakan adanya ketidaksesuaian antara tujuan dan peluang untuk mencampuri usaha pencapaian tujuan pihak lain.

Dari kedua definisi konflik yang diungkapkan di atas, dapat disimpulkan bahwa Pengertian Konflik adalah proses yang dinamis dan keberadaannya lebih banyak menyangkut persepsi dan orang atau pihak yang merasakan dan mengalaminya. Jika suatu keadaan tidak dirasakan sebagai konflik, maka pada dasarnya konflik tersebut tidak ada dan begitupun sebaliknya.

\section{Jenis Jenis Konflik}

Jenis jenis konflik dibedakan dalam beberapa perspektif. antara lain :

a. Konflik intraindividu. Konflik ini dialami oleh individu dengan dirinya sendiri karena adanya 
tekanan peran dan ekpektasi di luar berbeda dengan keinginan atau harapannya.

b. Konflik antarindividu. Konflik yang terjadi antarindividu yang berada dalam suatu kelompok atau antarindividu pada kelompok yang berbeda

c. Konflik antarkelompok. Konflik yang bersifat kolektif antara satu kelompok dengan kelompok lain.

d. Konflik organisasi. Konflik yang terjadi antara unit organisasi yang bersifat struktural maupun fungsional. Contoh : konflik antara bagian pemasaran dengan bagian produksi.

3. Jenis Jenis konflik ditinjau dari jenisnya, yaitu :

a. Konflik Konstruktif

Pengertian Konflik konstruktif adalah konflik yang memiliki nilai positif bagi pengembangan organisasi.

b. Konflik Destruktif

Pengertian Konflik Destruktif ialah konflik yang berdampak negatif bagi pengembangan organisasi.

4. Jenis Jenis Konflik dari segi instansionalnya, yaitu :

a. Konflik kebutuhan individu dengan peran yang dimainkan dalam organisasinya. Tidak jarang kebutuhan dan keinginan karyawan bertentangan atau tidak sejalan dengan kebutuhan dan kepentingan organisasi. Hal ini dapat memunculkan konflik. 
b. Konflik peranan dengan peranan. Setiap karyawan dari organisasi memiliki peran yang berbeda-beda dan ada kalanya perbedaan peran tiap individu tersebut memunculkan konflik karena setiap individu berusaha untuk memainkan peran tersebut dengan sebaik-baiknya.

c. Konflik individu dengan individu lainnya. Konflik ini seringkali muncul apabila seorang individu berinteraksi dengan individu lain, disebabkan oleh latarbelakang, pola tindak, pola pikir, kepribadian, persepsi, minat dan sejumlah karakteristik yang berbeda antara satu dengan yang lain.

5. Jenis Jenis Konflik ditinjau dari segi materi atau masalah yang menjadi sumber konflik, yaitu :

a. Konflik tujuan. Adanya perbedaan tujuan antarindividu, kelompok maupun organisasi bisa memunculkan konflik.

b. Konflik peranan. Setiap manusia memiliki peran lebih dari satu. Peran yang dimainkan dengan jumlah yang banyak tersebut, seringkali memunculkan konflik.

c. Konflik nilai. Nilai yang dianut seseorang seringkali tidak sejalan dengan sistem nilai yang diatur oleh organisasi atau kelompok. Hal ini dapat berpotensi untuk memunculkan konflik

d. Konflik kebijakan. Konflik ini muncul karena seorang individu atau kelompok tidak sependapat dengan kebijakan yang ditetapkan organisasi. 


\section{Jenis Jenis Konflik menurut Mastenbroek ada 4, yaitu}

a. Instrumental Conflicts

Konflik ini terjadi oleh karena ketidaksepahaman antarkomponen dalam organisasi dan proses pengoperasiannya.

b. Socio-emotional Conflicts

Konflik ini berkaitan dengan masalah identitas, kandungan emosi, citra diri, prasangka, kepercayaan, keterikatan, identifikasi terhadap kelompok, lembaga dan lambang-lambang tertentu, sistem nilai dan reaksi individu dengan yang lainnya.

c. Negotiating Conflicts

Konflik negosiasi adalah keteganganketegangan yang dirasakan pada waktu proses negosiasi terjadi, baik antara individu dengan individu atau kelompok dengan kelompok.

d. Power and Dependency Conflicts

Konflik kekuasaan dan ketergantungan berkaitan dengan persaingan dalam organisasi. Contoh : pengamanan dan penguatan kedudukan yang strategis.

\section{Ada tiga pandangan mengenai konflik, yaitu :}

a. Pandangan Tradisional

Pandangan tradisional menyatakan bahwa konflik harus dihindari karena akan menimbulkan kerugian. Aliran ini memandang konflik sebagai sesuatu hal yang buruk, tidak menguntungkan dan juga selalu merugikan 
organisasi. Oleh karena itu konflik ini harus dicegah dan juga dihindari sebisa mungkin dengan mencari akan permasalahannya.

b. Pandangan Hubungan Kemanusiaan

Pandangan aliran behavioral ini menyatakan bahwa konflik merupakan sesuatu yang wajar, alamiah dan tidak dapat dihindarkan dalam setiap kelompok manusia. Konflik ini sebenarnya tidak selalu buruk karena memiliki potensi kekuatan yang positif di dalam menentukan kinerja kelompok. Konflik tidak selamanya hanya merugikan, bahkan bisa menguntungkan, yang oleh karena itu konflik harus dikelola dengan baik.

c. Pandangan Interaksionis

Pandangan ini menyatakan bahwa konflik bukan sekedar sesuatu kekuatan positif dalam suatu kelompok, namun juga mutlak diperlukan untuk suatu kelompok agar dapat berkinerja secara positif. Oleh karena itu konflik harus diciptakan. Pandangan ini berdasarkan pada keyakinan bahwa organisasi yang tenang, damai dan harmonis ini justru akan membuat organisasi itu menjadi statis, stagnan dan juga tidak inovatif. Dampaknya yaitu pada kinerja organisasi menjadi lemah.

\section{B. Penyebab Konflik Antar Kelompok}

Banyak orang berpendapat bahwa faktor-faktor penyebab konflik sosial terjadi karena adanya perebutan 
sesuatu yang jumlahnya terbatas. Adapula yang berpendapat bahwa konflik muncul karena adanya ketimpangan-ketimpangan dalam masyarakat, terutama antara kelas atas dan kelas bawah. Selain itu juga karena adanya perbedaan-perbedaan kepentingan, kebutuhan, dan tujuan dari masing masing anggota masyarakat. Sementara itu, Soerjono Soekanto mengemukakan bahwa sebab sebab terjadinya konflik antara lain sebagai berikut.

\section{Perbedaan Antar perorangan}

Perbedaan ini dapat berupa perbedaan perasaan, pendirian, atau pendapat. Hal ini mengingat bahwa manusia adalah individu yang unik atau istimewa, karena tidak pernah ada kesamaan yang baku antara yang satu dengan yang lain. Perbedaanperbedaan inilah yang dapat menjadi salah satu penyebab terjadinya konflik sosial, sebab dalam menjalani sebuah pola interaksi sosial, tidak mungkin seseorang akan selalu sejalan dengan individu yang lain. Misalnya dalam suatu diskusi kelas, kamu bersama kelompokmu kebetulan sebagai penyaji makalah.Pada satu kesempatan, ada temanmu yang mencoba untuk mengacaukan jalannya diskusi dengan menanyakan hal-hal yang sebetulnya tidak perlu dibahas dalam diskusi tersebut. Kamu yang bertindak selaku moderator melakukan interupsi dan mencoba meluruskan pertanyaan untuk kembali ke permasalahan pokok. Namun temanmu (si penanya) tadi menganggap kelompokmu payah dan tidak siap untuk menjawab pertanyaan. Perbedaan pandangan 
dan pendirian tersebut akan menimbulkan perasaan amarah dan benci yang apabila tidak ada kontrol terhadap emosional kelompok akan terjadi konflik.

\section{Perbedaan Kebudayaan}

Perbedaan kebudayaan mempengaruhi pola pemikiran dan tingkah laku perseorangan dalam kelompok kebudayaan yang bersangkutan. Selain perbedaan dalam tataran individual, kebudayaan dalam masing-masing kelompok juga tidak sama. Setiap individu dibesarkan dalam lingkungan kebudayaan yang berbeda-beda. Dalam lingkungan kelompok masyarakat yang samapun tidak menutup kemungkinan akan terjadi perbedaan kebudayaan, karena kebudayaan lingkungan keluarga yang membesarkannya tidak sama. Yang jelas, dalam tataran kebudayaan ini akan terjadi perbedaan nilai dan norma yang ada dalam lingkungan masyarakat. Ukuran yang dipakai oleh satu kelompok atau masyarakat tidak akan sama dengan yang dipakai oleh kelompok atau masyarakat lain.

Apabila tidak terdapat rasa saling pengertian dan menghormati perbedaan tersebut, tidak menutup kemungkinan faktor ini akan menimbulkan terjadinya konflik sosial. Contohnya seseorang yang dibesarkan pada lingkungan kebudayaan yang bersifat individualis dihadapkan pada pergaulan kelompok yang bersifat sosial. Dia akan mengalami kesulitan apabila suatu saat ia ditunjuk selaku pembuat kebijakan kelompok. Ada 
kecenderungan dia akan melakukan pemaksaan kehendak sehingga kebijakan yang diambil hanya menguntungkan satu pihak saja. Kebijakan semacam ini akan di tentang oleh kelompok besar dan yang pasti kebijakan tersebut tidak akan diterima sebagai kesepakatan bersama. Padahal dalam kelompok harus mengedepankan kepentingan bersama. Di sinilah letak timbulnya pertentangan yang disebabkan perbedaan kebudayaan. Contoh lainnya adalah seseorang yang berasal dari etnis $A$ yang memiliki kebudayaan $A$, pindah ke wilayah $B$ dengan kebudayaan $B$. Jika orang tersebut tetap membawa kebudayaan asal dengan konservatif, tentu saja ia tidak akan diterima dengan baik di wilayah barunya. Dengan kata lain meskipun orang tersebut memiliki pengaruh yang kuat, alangkah lebih baik jika tetap melakukan penyesuaian terhadap kebudayaan tempat tinggalnya yang baru.

\section{Bentrokan Kepentingan}

Bentrokan kepentingan dapat terjadi di bidang ekonomi, politik, dan sebagainya. Hal ini karena setiap individu memiliki kebutuhan dan kepentingan yang berbeda dalam melihat atau mengerjakan sesuatu. Demikian pula halnya dengan suatu kelompok tentu juga akan memiliki kebutuhan dan kepentingan yang tidak sama dengan kelompok lain. Misalnya kebijakan mengirimkan pemenang Putri Indonesia untuk mengikuti kontes 'Ratu Sejagat' atau 'Miss Universe'. Dalam hal ini pemerintah menyetujui pengiriman tersebut, karena dipandang sebagai kepentingan untuk 
promosi kepariwisataan dan kebudayaan. Di sisi lain kaum agamis menolak pengiriman itu karena dipandang bertentangan dengan norma atau adat ketimuran (bangsa Indonesia). Bangsa Indonesia yang selama ini dianggap sebagai suatu bangsa yang menjunjung tinggi budaya timur yang santun, justru merelakan wakilnya untuk mengikuti kontes yang ternyata di dalamnya ada salah satu persyaratan yang mengharuskan untuk berfoto menggunakan swim suit (pakaian untuk berenang).

\section{Perubahan Sosial yang Terlalu Cepat di dalam Masyarakat}

Perubahan tersebut dapat menyebabkan terjadinya disorganisasi dan perbedaan pendirian mengenai reorganisasi dari sistem nilai yang baru. Perubahan-perubahan yang terjadi secara cepat dan mendadak akan membuat keguncangan prosesprosessosial di dalam masyarakat, bahkan akan terjadi upaya penolakan terhadap semua bentuk perubahan karena dianggap mengacaukan tatanan kehidupan masyarakat yang telah ada. Sebenarnya perubahan adalah sesuatu yang wajar terjadi, namun jika terjadinya secara cepat akan menyebabkan gejolak sosial, karena adanya ketidaksiapan dan keterkejutan masyarakat, yang pada akhirnya akan menyebabkan terjadinya konflik sosial. Contohnya kenaikan BBM, termasuk perubahan yang begitu cepat. Masyarakat banyak yang kurang siap dan kemudian menimbulkan aksi penolakan terhadap perubahan tersebut. Selain 
yang disebutkan di atas, proses sosial dalam masyarakat ada juga yang menyebabkan atau berpeluang menimbulkan konflik adalah persaingan dan kontravensi.

\section{a. Persaingan (Competition)}

Dalam persaingan individu atau kelompok berusaha mencari keuntungan melalui bidangbidang kehidupan yang pada suatu masa tertentu menjadi pusat perhatian umum. Cara yang dilakukan untuk mencapai tujuan itu adalah dengan menarik perhatian atau mempertajam prasangka yang telah ada tanpa menggunakan ancaman atau kekerasan. Jika dikelompokkan, ada dua macam persaingan, yaitu persaingan yang bersifat pribadi dan tidak pribadi atau kelompok. Persaingan pribadi merupakan persaingan yang dilakukan orang per orang atau individu untuk memperoleh kedudukan dalam organisasi. Persaingan kelompok, misalnya terjadi antara dua macam perusahaan dengan produk yang sama untuk memperebutkan pasar di suatu wilayah. Persaingan pribadi dan kelompok menghasilkan beberapa bentuk persaingan, antara lain persaingan di bidang ekonomi, kebudayaan, kedudukan dan peranan, dan persaingan ras. 
1. Persaingan di Bidang Kebudayaan

Persaingan di bidang kebudayaan merupakan persaingan antara dua kebudayaan untuk memperebutkan pengaruh di suatu wilayah. Persaingan kebudayaan misalnya terjadi antara kebudayaan pendatang dengan kebudayaan penduduk asli. Bangsa pendatang akan berusaha agar kebudayaannya dipakai di wilayah di mana ia datang. Begitu pula sebaliknya, penduduk asli akan berusaha agar bangsa pendatang menggunakan kebudayaannya dalam kehidupan.

2. Persaingan Kedudukan dan Peranan

Apabila dalam diri seseorang atau kelompok terdapat keinginan-keinginan untuk diakui sebagai orang atau kelompok yang mempunyai kedudukan dan peranan terpandang maka terjadilah persaingan. Kedudukan dan peranan yang dikejar tergantung pada apa yang paling dihargai oleh masyarakat pada suatu masa tertentu.

3. Persaingan Ras

Persaingan ras sebenarnya juga merupakan persaingan di bidang kebudayaan. Perbedaan ras baik perbedaan 
warna kulit, bentuk tubuh, maupun corak rambut hanya merupakan suatu perlambang kesadaran dan sikap atau perbedaanperbedaan dalam kebudayaan. Persaingan dalam batas-batas tertentu memiliki fungsi.

\section{b. Fungsi Persaingan}

Berikut ini adalah beberapa fungsi persaingan:

1. Alat untuk mengadakan seleksi atas dasar jenis kelamin dan sosial;

2. Menyalurkan keinginan individu atau kelompok yang bersifat kompetitif;

3. Jalan untuk menyalurkan keinginan, kepentingan, serta nilai-nilai yang pada suatu masa tertentu menjadi pusat perhatian sehingga tersalurkan dengan baik oleh mereka yang bersaing;

4. Alat untuk menyaring para warga golongan fungsional sehingga menghasilkan pembagian kerja yang efektif.

Persaingan dalam segala bentuknya akan menghasilkan hal-hal yang bersifat positif maupun negatif. Hal-hal positif yang dihasilkan dengan adanya persaingan, antara lain makin kuatnya solidaritas kelompok, dicapainya kemajuan, dan terbentuknya kepribadian seseorang (baca juga: mengenal sifat pluralisme budaya). 
1. Makin Kuatnya Solidaritas Kelompok

Persaingan yang dilakukan dengan jujur akan menyebabkan individu saling menyesuaikan diri dalam hubungan sosialnya. Dengan demikian, keserasian dalam kelompok akan tercapai. Hal itu bisa tercapai apabila persaingan dilakukan dengan jujur.

\section{Dicapainya Kemajuan}

Persaingan akan lebih banyak dijumpai pada masyarakat yang maju dan berkembang pesat. Untuk itu, individu yang berada dalam masyarakat tersebut harus mampu menyesuaikan diri dengan keadaan tersebut. Persaingan akan menyebabkan seseorang terdorong untuk bekerja keras supaya dapat berperan dalam masyarakat.

3. Terbentuknya Kepribadian Seseorang

Persaingan yang dilakukan dengan jujur dapat menimbulkan tumbuhnya rasa sosial dalam diri seseorang. Namun sebaliknya, persaingan juga bisa menimbulkan hal yang negatif, yaitu terciptanya disorganisasi. Adanya disorganisasi karena masyarakat hampir tidak diberi kesempatan untuk menyesuaikan diri dan 
melakukan reorganisasi saat terjadi perubahan. Hal itu disebabkan karena perubahan yang terjadi bersifat cepat atau revolusi.

\section{c. Kontravensi}

Kontravensi berasal dari bahasa Latin, contra dan venire yang berarti menghalangi atau menantang. Kontravensi merupakan usaha untuk menghalang-halangi pihak lain dalam mencapai tujuan. Tujuan utama tindakan dalam kontravensi adalah menggagalkan tercapainya tujuan pihak lain. Hal itu dilakukan karena rasa tidak senang atas keberhasilan pihak lain yang dirasa merugikan. Namun demikian, dalam kontravensi tidak ada maksud untuk menghancurkan pihak lain.

Menurut Leopold von Wiese dan Howard Becker ada lima macam bentuk kontravensi.

a. Kontravensi umum, antara lain dilakukan dengan penolakan, keengganan, perlawanan, perbuatan menghalanghalangi, protes, gangguangangguan, dan kekerasan.

b. Kontravensi sederhana, antara lain dilakukan dengan menyangkal pernyataan pihak lain di depan umum, memakimaki 
orang lain melalui selebaran, mencerca, dan memfitnah.

c. Kontravensi intensif, antara lain dilakukan dengan menghasut, menyebarkan desasdesus, dan mengecewakan pihak lain.

d. Kontravensi rahasia, antara lain dilakukan dengan pengkhianatan dan mengumumkan rahasia pihak lain.

e. Kontravensi taktis, antara lain dilakukan dengan mengejutkan lawan dan mengganggu pihak lain.

\section{Cara Mengelola Konflik}

1. Akibat-akibat Konflik Konflik dapat berakibat negatif maupun positif tergantung pada cara mengelola konflik tersebut. Akibat negatif

- Menghambat komunikasi.

- Mengganggu kohesi (keeratan hubungan).

- Mengganggu kerjasama atau "team work".

- Mengganggu proses produksi, bahkan dapat menurunkan produksi.

- Menumbuhkan ketidakpuasan terhadap pekerjaan.

- Individu atau personil menga-lami tekanan (stress), mengganggu konsentrasi, menimbulkan kecemasan, mangkir, menarik diri, frustrasi, dan apatisme. 
Akibat Positif dari konflik:

- Membuat organisasi tetap hidup dan harmonis.

- Berusaha menyesuaikan diri dengan lingkungan.

- Melakukan adaptasi, sehingga dapat terjadi perubahan dan per-baikan dalam sistem dan prosedur, mekanisme, program, bahkan tujuan organisasi.

- Memunculkan keputusan-keputusan yang bersifat inovatif.

- Memunculkan persepsi yang lebih kritis terhadap perbedaan pendapat.

2. Cara atau Taktik Mengatasi Konflik

Mengatasi dan menyelesaikan suatu konflik bukanlah suatu yang sederhana. Cepat-tidaknya suatu konflik dapat diatasi tergantung pada kesediaan dan keterbukaan pihak-pihak yang bersengketa untuk menyelesaikan konflik, berat ringannya bobot atau tingkat konflik tersebut serta kemampuan campur tangan (intervensi) pihak ketiga yang turut berusaha mengatasi konflik yang muncul.

Diatasi oleh pihak-pihak yang bersengketa:

a. Rujuk: Merupakan suatu usaha pendekatan dan hasrat untuk kerja-sama dan menjalani hubungan yang lebih baik, demi kepentingan bersama.

b. Persuasi: Usaha mengubah po-sisi pihak lain, dengan menunjukkan kerugian yang mungkin timbul, dengan bukti faktual serta dengan 
menunjukkan bahwa usul kita menguntungkan dan konsisten dengan norma dan standar keadilan yang berlaku.

c. Tawar-menawar: Suatu penyelesaian yang dapat diterima kedua pihak, dengan saling mempertukarkan konsesi yang dapat diterima. Dalam cara ini dapat digunakan komunikasi tidak langsung, tanpa mengemukakan janji secara eksplisit.

d. Pemecahan masalah terpadu: Usaha menyelesaikan masalah dengan memadukan kebutuhan kedua pihak. Proses pertukaran informasi, fakta, perasaan, dan kebutuhan berlangsung secara terbuka dan jujur. Menimbulkan rasa saling percaya dengan merumuskan alternatif pemecahan secara bersama dengan keuntungan yang berimbang bagi kedua pihak.

e. Penarikan diri: Suatu penyelesaian masalah, yaitu salah satu atau kedua pihak menarik diri dari hubungan. Cara ini efektif apabila dalam tugas kedua pihak tidak perlu berinteraksi dan tidak efektif apabila tugas saling bergantung satu sama lain.

f. Pemaksaan dan penekanan: Cara ini memaksa dan menekan pihak lain agar menyerah; akan lebih efektif bila salah satu pihak mempunyai wewenang formal atas pihak lain. Apabila tidak terdapat perbedaan wewenang, dapat dipergunakan ancaman atau bentuk-bentuk intimidasi lainnya. Cara ini sering kurang efektif 
karena salah satu pihak hams mengalah dan menyerah secara

terpaksa.

\section{Intervensi (campur tangan) pihak ketiga:}

Apabila pihak yang bersengketa tidak bersedia berunding atau usaha kedua pihak menemui jalan buntu, maka pihak ketiga dapat dilibatkan dalam penyelesaian konflik.

a. Arbitrase (arbitration): Pihak ketiga mendengarkan keluhan kedua pihak dan berfungsi sebagai "hakim" yang mencari pemecahan mengikat. Cara ini mungkin tidak menguntungkan kedua pihak secara sama, tetapi dianggap lebih baik daripada terjadi muncul perilaku saling agresi atau tindakan destruktif.

b. Penengahan (mediation): Menggunakan mediator yang diundang untuk menengahi sengketa. Mediator dapat membantu mengumpulkan fakta, menjalin komunikasi yang terputus, menjernihkan dan memperjelas masalah serta mela-pangkan jalan untuk pemecahan masalah secara terpadu. Efektivitas penengahan tergantung juga pada bakat dan ciri perilaku mediator.

c. Konsultasi: Tujuannya untuk memperbaiki hubungan antar kedua pihak serta mengembangkan kemampuan mereka sendiri untuk menyelesaikan konflik. Konsultan tidak mempunyai wewenang untuk memutuskan dan tidak berusaha 
untuk menengahi. la menggunakan berbagai teknik untuk meningkatkan persepsi dan kesadaran bahwa tingkah laku kedua pihak terganggu dan tidak berfungsi, sehingga menghambat proses penyelesaian masalah yang menjadi pokok sengketa.

3. Hal-hal yang Perlu Diperhati-kan Dalam Mengatasi Konflik:

a. Ciptakan sistem dan pelaksanaan komunikasi yang efektif.

b. Cegahlah konflik yang destruktif sebelum terjadi.

c. Tetapkan peraturan dan prosedur yang baku terutama yang menyangkut hak karyawan.

d. Atasan mempunyai peranan penting dalam menyelesaikan konflik yang muncul.

e. Ciptakanlah iklim dan suasana kerja yang harmonis.

f. Bentuklah team work dan kerja-sama yang baik antar kelompok/ unit kerja.

g. Semua pihak hendaknya sadar bahwa semua unit/eselon merupakan mata rantai organisasi yang saling mendukung, jangan ada yang merasa paling hebat.

h. Bina dan kembangkan rasa solidaritas, toleransi, dan saling pengertian antar unit/departemen/ eselon. 


\section{BAB 8}

\section{Kekuasaan Politik dan Pemberdayaan}

\section{A. Konsep Kekuasaan}

Gagasan tradisional tentang kekuasaan memfokuskan pada individu dan pelaksanaan kekuasaannya. French dan Raven mendasarkan kekuasaan A terhadap B pada lima jenis kekuasaan yaitu:

1. Kekuasaan memberi ganjaran,(Reward Power), dapatkah A memberikan ganjaran yang dapat dirasakan oleh B.

2. Kekuasaan yang memaksa,(Coersive Power), dapatkah A memberikan sesuatu hukuman yang dianggap hukuman oleh B.

3. Kekuasaan yang sah,(Legitimate Power),Apakah B percaya bahwa $A$ memiliki hak untuk mempengaruhi $B$ dan $B$ harus menerimanya,mungkin penerimaan terhadap struktur sosial atau nilai-nilai budaya.

4. Kekuasaan referen,(Referent Power), Apakah B mengenal A, apakah B ingin seperti A, apakah B memiliki keinginan merasakan satu kesatuan dengan $A$.

5. Kekuasaan ahli, (Expert Power), Apakah B percaya bahwa A memiliki pengetahuan atau keahlian khusus yang berguna atau diperlukan untuk kebaikan atau untuk memenuhi harapan $\mathrm{B}$.

Organisasi dan kekuasaan hendaknya memiliki interaksi yang sangat erat. Sama halnya dengan struktur organisasi,kekuasaan tidak dapat mempertahankan dirinya 
tanpa orang-orang yang mengesahkan dirinya melalui perilaku,sementara itu orang di dalam organisasi melakukan usaha untuk mencapai tujuan organisasi diperlukan sebuah kekuasaan.

Jadi dapat dikatakan bahwa dalam dinamika organisasi, kekuasaan sangat diperlukan. Boulding menemukan ada 3 jenis kekuasaan dalam mempertahankan organisasi yaitu:

1. Kekuasaan bersifat menghancurkan,menghasilkan, dan menyatukan.Kekuasaan destruktif adalah kekuasaan untuk potensi menghancurkan dan mengancam.

2. Kekuasaan produktif atau menghasilkan bersifat ekonomik dan meliputi kekuasaan untuk menghasilkan dan menjual.

3. Kekuasaan integrative berarti mendorong kesetiaan,menyatukan orang bersama dan mampu menggerakan orang ke arah tujuan bersama.Menurut Boulding kekuasaan integratif adalah bentuk kekuasaan yang paling dominan.

Komunikasi dipakai untuk maksud tertentu seperti memberi instruksi, membujuk atau memperoleh kekuasaan. Komunikasi dipandang sebagai mekanisme kekuasaan,dalam konteks organisasi komunikasi digunakan untuk menentukan tujuan, norma dan perilaku organisasi. organisasi dapat dipandang sebagai suatu sarana kekuasaan. Manusia memiliki kekuasaan,melaksanakannya melalui komunikasi dan menciptakan tindakan yang 
terorganisir. Komunikasi juga dipandang sebagai kekuasaan karena kemampuannya untuk menentukan hasil, pengetahuan, keyakinan, dan tindakan. Manusia bertindak berdasarkan informasi yang ada serta pilihan atau alternatif yang disediakan oleh informasi tersebut. Kekuasaan digunakan melalui alternatif yang disediakan dan cara alternatif tersebut diberikan. Sebagai contoh misalnya organisasi memberikan kesempatan anggotanya membuat keputusan tetapi tidak bebas samasekali melainkan memberikan pedoman atau kriteria yang harus dipenuhi dalam setiap pengambilan keputusan tersebut.

\section{B. Pemberdayaan}

Istilah pemberdayaan telah menjadi bagian dari bahasa sehari-hari manajemen. Strategi lain yang digunakan oleh organisasi untuk mengembangkan karyawan dalam menghadapi permasalahan organsasi adalah dengan cara memberdayakan karyawan. Pemberdayaan merupakan otoritas dalam membuat keputusan di area tanggung jawab seseorang tanpa meminta persetujuan orang lain. Istilah "pemberdayaan" umumnya digunakan untuk merujuk kepada sebuah bentuk keterlibatan karyawan inisiatif yang meluas dari tahun 1980-an dan memusatkan perhatian pada tugas berbasis keterlibatan dan perubahan sikap.

Pendapat lain menyatakan bahwa pemberdayaan merupakan salah satu cara pengembangan karyawan melalui employee involvement yaitu dengan memberi wewenang tanggung jawab yang cukup untuk menyelesaikan tugas dan pengambilan keputusan. (Chaudron, 1995). Penerapan pemberdayaan dalam 
organisasi, terdapat hubungan antara kekuasaan dengan kepercayaan diri, otoritas manajerial, dan pengharapan terhadap komitmen kontributor. Walaupun pemberdayaan sama dengan delegasi wewenang, ada dua karakteristik yang menjadikannya unik. Pertama, karyawan didukung untuk memakai inisiatif mereka sendiri. Kedua, pemberdayaan karyawan tidak hanya memberi otoritas, tetapi juga sumber daya sehingga mereka mampu membuat keputusan dan memiliki kekuasaan untuk diimplementasikan. Pemberdayaan bermaksud meniadakan segala peraturan, prosedur, perintah, dan lainlain yang tidak perlu, yang merintangi organisasi untuk mencapai tujuannya. Pemberdayaan bertujuan menghapuskan hambatan-hambatan sebanyak mungkin guna membebaskan organisasi dan orang-orang yang bekerja di dalamnya, melepaskan mereka dari halanganhalangan yang hanya memperlamban reaksi dan merintangi aksi mereka (Stewart, 1998). Dalam pemberdayaan karyawan dianggap bersedia menerima tanggung jawab dan bersedia meningkatkan pekerjaan serta relasi seharihari. (Arthur, 1994).

Partisipasi dalam pengambilan keputusan berkisar mulai dari manager menanyakan pendapat segelintir pekerja sampai sang manager melibatkan semua pekerja dalam pengambilan keputusan suatu kelompok. Sebuah studi dari partisipasi pegawai (pemberdayaan) dalam promosi, evaluasi pekerjaan konten, teknologi berubah, bekerja standar, kebijakan keuangan, biaya kontrol, struktur organisasi, ukuran angkatan kerja, programprogram keselamatan, metode kerja, dan harga. Seperti 
halnya yang dikemukakan oleh Kanter (1977) bahwa model pemberdayaan organisasi menawarkan kerangka untuk menciptakan lingkungan kerja yang bermakna bagi karyawan yang profesional. Kanter menggambarkan pemberdayaan sebagai sebuah kekuatasn listrik. Bila daya telah "menyala", maka karyawan memiliki akses ke saluran informasi, dukungan, sumber daya, dan kesempatan untuk belajar dan berkembang. Ketika "saluran" atau sumber dari daya tersebut tidak tersedia, maka daya akan mati dan efektifitas kerja adalah mustahil. Suatu komponen penting dalam proses pemberdayaan adalah saling percaya. Bila lingkungan kerja adalah memberdayakan dan karyawan melihat iklim keadilan, menghargai, dan mempercayai, adalah wajar untuk mengharapkan karyawan lebih mengalami kepuasan kerja dan komitmen organisasi. Secara psikologis pemberdayaan ini memungkinkan karyawan untuk menanggulangi stress kerja, sehingga akan dapat meningkatkan loyalitas karyawan pada organisasi. Pemberdayaan karyawan telah memberikan beberapa karyawan beberapa tingkat tanggung jawab dan otonomi untuk membuat keputusan terkait dengan tugas-tugas spesifik dari organisasi. Hal ini juga memungkinkan bahwa keputusan dibuat di tingkat yang lebih rendah dari organisasi di mana karyawan melihat masalah dengan cara yang unik dan tidak memiliki masalah saat menghadapi permasalahan pada organisasi mereka pada tingkat tertentu setelah satu titik. 
Kelebihan Pemberdayaan Karyawan

Kekurangan Pemberdayaan Karyawan

Meningkatkan

produktifitas dan Menyalahgunakan kekuasaan

mengurangi biaya

Memiliki layanan yang

lebih baik

Berkurangnya hubungan interpersonal

Dapat

menerima

perubahan

Biaya pelatihan menjadi bertambah

Meningkatkan kualitas

kerja

Arogansi karyawan

Kolaborasi

Turnover rendah

Resiko keamanan dan kerahasiaan

Program pemberdayaan karyawan memiliki kelebihan dan kelemahan. Karyawan yang diberdayakan diberikan fleksibilitas dan kebebasan untuk membantu membuat perubahan dalam lingkungan kerjanya. Karyawan yang merasa diberdayakan akan menghasilkan karya dengan kualitas sangat tinggi, mereka mampu menciptakan 
perasaan layanan pelanggan yang benar yang akan menghasilkan loyalitas pelanggan.

Sebagian besar karyawan yang diberdayakan cenderung menyalahgunakan kekuasaan mereka ketika mereka diberi kekuasaan untuk membuat keputusan sesuai keinginan mereka. Konflik dan kesalahpahaman antara karyawan dan manajer mereka bisa saja terjadi karena karyawan yang diberdayakan memiliki hirarki yang tinggi dan kaku.

Secara struktural, pemberdayaan berfokus pada praktik manajemen seperti pendelegasian pengambilan keputusan dari atas untuk menurunkan tingkat organisasi dan peningkatan akses terhadap informasi dan sumber daya di antara individu-individu pada tingkat yang lebih rendah. Pada tataran pemberdayaan ini dibutuhkan komitmen yang jelas dari manajemen perusahaan untuk benar-benar memberikan delegasi wewenang kepada pemegang jabatan, dan bukan hanya sekedar boneka belaka. Diperlukan pula integritas yang tinggi bagi pemegang jabatan untuk dapat menjaga kepercayaan yang telah diberikan oleh atasan sebagai suatu "amanah", sehingga tugas dapat berjalan dengan baik.

\section{Strategi Dan Taktik Politik}

\section{Strategi}

Definisi Strategi - Strategi adalah Rencana yang disatukan, luas dan berintegrasi yang menghubungkan keunggulan strategis perusahaan dengan tantangan lingkungan, yang dirancang untuk memastikan bahwa 
tujuan utama dari perusahaan dapat dicapai melalui pelaksanaan yang tepat oleh organisasi (Glueck dan Jauch, 1989). Kata strategi berasal dari bahasa Yunani "strategia" yang diartikan sebagai "the art of the general" atau seni seorang panglima yang biasanya digunakan dalam peperangan. definisi strategi secara umum dan khusus sebagai berikut:

a. Definisi Umum

Strategi adalah proses penentuan rencana para pemimpin puncak yang berfokus pada tujuan jangka panjang organisasi, disertai penyusunan suatu cara atau upaya bagaimana agar tujuan tersebut dapat dicapai.

b. Definisi khusus

Strategi merupakan tindakan yang bersifat incremental (senantiasa meningkat) dan terusmenerus, serta dilakukan berdasarkan sudut pandang tentang apa yang diharapkan oleh para pelanggan di masa depan. Dengan demikian, strategi hampir selalu dimulai dari apa yang dapat terjadi dan bukan dimulai dari apa yang terjadi. Terjadinya kecepatan inovasi pasar yang baru dan perubahan pola konsumen memerlukan kompetensi inti (core competencies). Perusahaan perlu mencari kompetensi inti di dalam bisnis yang dilakukan.

c. Perumusan Strategi

Perumusan strategi merupakan proses penyusunan langkah-langkah ke depan yang dimaksudkan untuk 
membangun visi dan misi organisasi, menetapkan tujuan strategis dan keuangan perusahaan, serta merancang strategi untuk mencapai tujuan tersebut dalam rangka menyediakan customer value terbaik.

Beberapa langkah yang perlu dilakukan perusahaan dalam merumuskan strategi, yaitu:

1. Mengidentifikasi lingkungan yang akan dimasuki oleh perusahaan di masa depan dan menentukan misi perusahaan untuk mencapai visi yang dicita-citakan dalam lingkungan tersebut.

2. Melakukan analisis lingkungan internal dan eksternal untuk mengukur kekuatan dan kelemahan serta peluang dan ancaman yang akan dihadapi oleh perusahaan dalam menjalankan misinya.

3. Merumuskan faktor-faktor ukuran keberhasilan (key success factors) dari strategi-strategi yang dirancang berdasarkan analisis sebelumnya.

4. Menentukan tujuan dan target terukur, mengevaluasi berbagai alternatif strategi dengan mempertimbangkan sumberdaya yang dimiliki dan kondisi eksternal yang dihadapi.

5. Memilih strategi yang paling sesuai untuk mencapai tujuan jangka pendek dan jangka panjang. (Hariadi, 2005).

d. Tingkat-tingkat Strategi

Dengan merujuk pada pandangan Dan Schendel dan Charles Hofer, Higgins (1985) menjelaskan adanya empat tingkatan strategi. Keseluruhannya 
disebut Master Strategy, yaitu: enterprise strategy, corporate strategy, business strategy dan functional strategy.

1. Enterprise Strategi

Strategi ini berkaitan dengan respons masyarakat. Setiap organisasi mempunyai hubungan dengan masyarakat. Masyarakat adalah kelompok yang berada di luar organisasi yang tidak dapat dikontrol. Di dalam masyarakat yang tidak terkendali itu, ada pemerintah dan berbagai kelompok lain seperti kelompok penekan, kelompok politik dan kelompok sosial lainnya. Jadi dalam strategi enterprise terlihat relasi antara organisasi dan masyarakat luar, sejauh interaksi itu akan dilakukan sehingga dapat menguntungkan organisasi. Strategi itu juga menampakkan bahwa organisasi sungguh-sungguh bekerja dan berusaha untuk memberi pelayanan yang baik terhadap tuntutan dan kebutuhan masyarakat.

2. Corporate Strategy

Strategi ini berkaitan dengan misi organisasi, sehingga sering disebut Grand Strategy yang meliputi bidang yang digeluti oleh suatu organisasi. Pertanyaan apa yang menjadi bisnis atau urusan kita dan bagaimana kita mengendalikan bisnis itu, tidak semata-mata untuk dijawab oleh organisasi bisnis, tetapi juga oleh setiap organisasi pemerintahan dan organisasi nonprofit. Apakah misi universitas yang utama? Apakah misi yayasan ini, yayasan 
itu, apakah misi lembaga ini, lembaga itu? Apakah misi utama direktorat jenderal ini, direktorat jenderal itu? Apakah misi badan ini, badan itu? Begitu seterusnya. Jawaban terhadap pertanyaan-pertanyaan itu sangat penting dan kalau keliru dijawab bisa fatal. Misalnya, kalau jawaban terhadap misi universitas ialah terjun kedalam dunia bisnis agar menjadi kaya maka akibatnya bisa menjadi buruk, baik terhadap anak didiknya, terhadap pemerintah, maupun terhadap bangsa dan negaranya. Bagaimana misi itu dijalankan juga penting. Ini memerlukan keputusan-keputusan stratejik dan perencanaan stratejik yang selayaknya juga disiapkan oleh setiap organisasi.

3. Business Strategy

Strategi pada tingkat ini menjabarkan bagaimana merebut pasaran di tengah masyarakat. Bagaimana menempatkan organisasi di hati para penguasa, para pengusaha, para donor dan sebagainya. Semua itu dimaksudkan untuk dapat memperoleh keuntungan-keuntungan stratejik yang sekaligus mampu menunjang berkembangnya organisasi ke tingkat yang lebih baik.

4. Functional Strategy

Strategi ini merupakan strategi pendukung dan untuk menunjang suksesnya strategi lain. Ada tiga jenis strategi functional yaitu: 
a. Strategi functional ekonomi yaitu mencakup fungsi-fungsi yang memungkinkan organisasi hidup sebagai satu kesatuan ekonomi yang sehat, antara lain yang berkaitan dengan keuangan, pemasaran, sumber daya, penelitian dan pengembangan.

b. Strategi functional manajemen, mencakup fungsi-fungsi manajemen yaitu planning, organizing, implementating, controlling, staffing, leading, motivating, communicating, decision making, representing, dan integrating.

c. Strategi isu stratejik, fungsi utamanya ialah mengontrol lingkungan, baik situasi lingkungan yang sudah diketahui maupun situasi yang belum diketahui atau yang selalu berubah (J. Salusu, p 101, 1996). Tingkat-tingkat strategi itu merupakan kesatuan yang bulat dan menjadi isyarat bagi setiap pengambil keputusan tertinggi bahwa mengelola organisasi tidak boleh dilihat dari sudut kerapian administratif semata, tetapi juga hendaknya memperhitungkan soal "kesehatan" organisasi dari sudut ekonomi (J. Salusu, $p$ 104, 1996).

e. Jenis-jenis Strategi

Banyak organisasi menjalankan dua strategi atau lebih secara bersamaan, namun strategi kombinasi dapat sangat beresiko jika dijalankan terlalu jauh. Di 
perusahaan yang besar dan terdiversifikasi, strategi kombinasi biasanya digunakan ketika divisi-divisi yang berlainan menjalankan strategi yang berbeda. Juga, organisasi yang berjuang untuk tetap hidup mungkin menggunakan gabungan dari sejumlah strategi defensif, seperti divestasi, likuidasi, dan rasionalisasi biaya secara bersamaan. Jenis-jenis strategi adalah sebagai berikut:

1. Strategi Integrasi

Integrasi ke depan, integrasi ke belakang, integrasi horizontal kadang semuanya disebut sebagai integrasi vertikal. Strategi integrasi vertikal memungkinkan perusahaan dapat mengendalikan para distributor, pemasok, dan / atau pesaing.

2. Strategi Intensif

Penetrasi pasar, dan pengembangan produk kadang disebut sebagai strategi intensif karena semuanya memerlukan usaha-usaha intensif jika posisi persaingan perusahaan dengan produk yang ada hendak ditingkatkan.

3. Strategi Diversifikasi

Terdapat tiga jenis strategi diversifikasi, yaitu diversifikasi konsentrik, horizontal, dan konglomerat. Menambah produk atau jasa baru, namun masih terkait biasanya disebut diversifikasi konsentrik. Menambah produk atau jasa baru yang tidak terkait untuk pelanggan yang sudah ada disebut diversifikasi horizontal. Menambah produk atau jasa baru yang tidak disebut diversifikasi konglomerat. 


\section{Strategi Defensi}

Disamping strategi integrative, intensif, dan diversifikasi, organisasi juga dapat menjalankan strategi rasionalisasi biaya, divestasi, atau likuidasi.

Rasionalisasi Biaya, terjadi ketika suatu organisasi melakukan restrukturisasi melalui penghematan biaya dan aset untuk meningkatkan kembali penjualan dan laba yang sedang menurun. Kadang disebut sebagai strategi berbalik (turnaround) atau reorganisasi, rasionalisasi biaya dirancang untuk memperkuat kompetensi pembeda dasar organisasi. Selama proses rasionalisasi biaya, perencana strategi bekerja dengan sumber daya terbatas dan menghadapi tekanan dari para pemegang saham, karyawan dan media. Divestasi adalah menjual suatu divisi atau bagian dari organisasi. Divestasi sering digunakan untuk meningkatkan modal yang selanjutnya akan digunakan untuk akusisi atau investasi strategis lebih lanjut. Divestasi dapat menjadi bagian dari strategi rasionalisasi biaya menyeluruh untuk melepaskan organisasi dari bisnis yang tidak menguntungkan, yang memerlukan modal terlalu besar, atau tidak cocok dengan aktivitas lainnya dalam perusahaan. Likuidasi adalah menjual semua aset sebuah perusahaan secara bertahap sesuai nilai nyata aset tersebut. Likuidasi merupakan pengakuan kekalahan dan akibatnya bisa 
merupakan strategi yang secara emosional sulit dilakukan. Namun, barangkali lebih baik berhenti beroperasi daripada terus menderita kerugian dalam jumlah besar.

5. Strategi Umum Michael Porter

Menurut Porter, ada tiga landasan strategi yang dapat membantu organisasi memperoleh keunggulan kompetitif, yaitu keunggulan biaya, diferensiasi, dan fokus. Porter menamakan ketiganya strategi umum. Keunggulan biaya menekankan pada pembuatan produk standar dengan biaya per unit sangat rendah untuk konsumen yang peka terhadap perubahan harga. Diferensiasi adalah strategi dengan tujuan membuat produk dan menyediakan jasa yang dianggap unik di seluruh industri dan ditujukan kepada konsumen yang relatif tidak terlalu peduli terhadap perubahan harga. Fokus berarti membuat produk dan menyediakan jasa yang memenuhi keperluan sejumlah kelompok kecil konsumen.

2. Taktik Politik

Taktik adalah bagian dari strategi. Karenanya taktik baru tunduk dan mengabdi kepada strategi. Rencana perjuangan (strategi) meliputi perjuangan secara menyeluruh baik dalam hubungan daerah, nasional dan internasional maupun mengenai semua segi penghidupan dan kehidupan masyarakat/Negara, ekonomi, hankam, kebudayaan, agama dan lain-lain.

a. Kedudukan Stratak dalam Perjuangan Ideologi 
Stratak tidaklah berdiri sendiri melainkan hanya merupakan alat pelaksana untuk mencapai tujuan (ideology. Karenanya stratak harus mengabdi kepada perjuangan untuk mencapai tujuan odeologi.

b. Tugas Utama Strategi dan Taktik

Sebagai cara menggunakan organisasi untuk mencapai rencana perjuangan dalam jangka waktu tertentu, serta sebagai cara berjuang menentukan sikap pada saat tertentu menghadapi masalah politik tertentu, maka tugas stratak adalah menciptakan, memelihara, dan menambah syarat-syarat yang akan membawa kepada tujuan. Syarat-syarat yang meliputi kekuatan fisik berupa tenaga manusia, kekuatan mental, kekuatan materil serta posisi didalam Negara dan masyarakat. Tegasnya tugas stratak adalah untuk machts-vorming dan machtanwending.

Macht : power $=$ kekuasaan

Kracht : force kekuatan

Power : force + position

Macht $=$ kracht + posisi

Kekuasaan $=$ kekuatan + posisi

Position without force $=$ nekad position

Force without position nekad force

Posisi tanpa kekuatan = posisi mentah

Kekautan tanpa posisi = kekuatan mentah

Position - force without ideologi $=$ nekad power 
Posisi tidak dapat dipisahkan dengan kekuatan. Posisi yang baik = separuh kekuatan . Posisi strategis adalah menentukan berhasil tidaknya rencana perjuangan (strategi). Posisi taktis menentukan berhasil tidaknya langkahlangkah taktik. Machts-vorming dan machtsanwending yang menjadi tugas stratak tidak lain tujuannya melainkan apa yang disebut Mao Tse Tung: bahwa tugas stratak ialah untuk mempertahankan/menambah kekuatan dan atau posisi sendiri serta menghancurkan atau mengurangi kekuatan dan atau posisi lawan. Baik buruknya suatu staratak ditentukan oleh berhasil tidaknya mempertahankan kekuatan sendiri atau mengurangi kekuatan lawan. Demikian pula baik buruknya leadership tidak terletak pada tegas atau tidaknya, berani atau tidak, populer atau tidak melainkan kepada hasil kepemimpinannya dan hasil dalam kepemimpinan ialah apa saja yang dapat mempertahankan kekuatan/posisi sendiri serta yang dapat mengurangi kekuatan atau posisi lawan.

\section{Etika, Kekuasaan Dan Politik}

\section{Etika}

Etika (Yunani Kuno: "ethikos", berarti "timbul dari kebiasaan") adalah sebuah sesuatu di mana dan bagaimana cabang utama filsafat yang mempelajari nilai atau kualitas yang menjadi studi mengenai standar dan penilaian moral Etika mencakup analisis dan 
penerapan konsep seperti benar, salah, baik, buruk, dan tanggung jawab. St. John of Damascus (abad ke-7 Masehi) menempatkan etika di dalam kajian filsafat praktis (practical philosophy).

Etika dimulai bila manusia merefleksikan unsur-unsur etis dalam pendapat-pendapat spontan kita. Kebutuhan akan refleksi itu akan kita rasakan, antara lain karena pendapat etis kita tidak jarang berbeda dengan pendapat orang lain. ${ }^{[1]}$ Untuk itulah diperlukan etika, yaitu untuk mencari tahu apa yang seharusnya dilakukan oleh manusia.

Secara metodologis, tidak setiap hal menilai perbuatan dapat dikatakan sebagai etika. Etika memerlukan sikap kritis, metodis, dan sistematis dalam melakukan refleksi. Karena itulah etika merupakan suatu ilmu. Sebagai suatu ilmu, objek dari etika adalah tingkah laku manusia. Akan tetapi berbeda dengan ilmu-ilmu lain yang meneliti juga tingkah laku manusia, etika memiliki sudut pandang normatif. Maksudnya etika melihat dari sudut baik dan buruk terhadap perbuatan manusia.

Etika terbagi menjadi tiga bagian utama: meta-etika (studi konsep etika), etika normatif (studi penentuan nilai etika), dan etika terapan (studi penggunaan nilainilai etika). 


\section{a. Jenis ETIKA}

\section{Etika Filosofis}

Etika filosofis secara harfiah dapat dikatakan sebagai etika yang berasal dari kegiatan berfilsafat atau berpikir, yang dilakukan oleh manusia. Karena itu, etika sebenarnya adalah bagian dari filsafat; etika lahir dari filsafat. Etika termasuk dalam filsafat, karena itu berbicara etika tidak dapat dilepaskan dari filsafat. Karena itu, bila ingin mengetahui unsur-unsur etika maka kita harus bertanya juga mengenai unsur-unsur filsafat. Berikut akan dijelaskan dua sifat etika:

a. Non-empiris

Filsafat digolongkan sebagai ilmu non-empiris. Ilmu empiris adalah ilmu yang didasarkan pada fakta atau yang konkret. Namun filsafat tidaklah demikian, filsafat berusaha melampaui yang konkret dengan seolah-olah menanyakan apa di balik gejala-gejala konkret. Demikian pula dengan etika. Etika tidak hanya berhenti pada apa yang konkret yang secara faktual dilakukan, tetapi bertanya tentang apa yang 
seharusnya dilakukan atau tidak boleh dilakukan.

b. Praktis

Cabang-cabang filsafat berbicara mengenai sesuatu "yang ada". Misalnya filsafat hukum mempelajari apa itu hukum. Akan tetapi etika tidak terbatas pada itu, melainkan bertanya tentang "apa yang harus dilakukan". Dengan demikian etika sebagai cabang filsafat bersifat praktis karena langsung berhubungan dengan apa yang boleh dan tidak boleh dilakukan manusia. Tetapi ingat bahwa etika bukan praktis dalam arti menyajikan resep-resep siap pakai. Etika tidak bersifat teknis melainkan reflektif. Maksudnya etika hanya menganalisis tema-tema pokok seperti hati nurani, kebebasan, hak dan kewajiban, dsb, sambil melihat teori-teori etika masa lalu untuk menyelidiki kekuatan dan kelemahannya. Diharapakan kita mampu menyusun sendiri argumentasi yang tahan uji.

\section{Etika Teologis}

Ada dua hal yang perlu diingat berkaitan dengan etika teologis. Pertama, etika 
teologis bukan hanya milik agama tertentu, melainkan setiap agama dapat memiliki etika teologisnya masing-masing. Kedua, etika teologis merupakan bagian dari etika secara umum, karena itu banyak unsur-unsur di dalamnya yang terdapat dalam etika secara umum, dan dapat dimengerti setelah memahami etika secara umum.

Secara umum, etika teologis dapat didefinisikan sebagai etika yang bertitik tolak dari presuposisi-presuposisi teologis. Definisi tersebut menjadi kriteria pembeda antara etika filosofis dan etika teologis. Di dalam etika Kristen, misalnya, etika teologis adalah etika yang bertitik tolak dari presuposisi-presuposisi tentang Allah atau Yang llahi, serta memandang kesusilaan bersumber dari dalam kepercayaan terhadap Allah atau Yang Ilahi. Karena itu, etika teologis disebut juga oleh Jongeneel sebagai etika transenden dan etika teosentris. Etika teologis Kristen memiliki objek yang sama dengan etika secara umum, yaitu tingkah laku manusia. Akan tetapi, tujuan yang hendak dicapainya sedikit berbeda, yaitu mencari apa yang seharusnya dilakukan manusia, dalam hal baik atau buruk, sesuai dengan kehendak Allah. Setiap agama dapat memiliki etika teologisnya yang unik berdasarkan apa yang diyakini dan menjadi sistem nilai-nilai yang dianutnya. Dalam hal ini, 
antara agama yang satu dengan yang lain dapat memiliki perbedaan di dalam merumuskan etika teologisnya.

3. Relasi Etika Filosofis dan Etika Teologis[sunting I sunting sumber]

Terdapat perdebatan mengenai posisi etika filosofis dan etika teologis di dalam ranah etika. Sepanjang sejarah pertemuan antara kedua etika ini, ada tiga jawaban menonjol yang dikemukakan mengenai pertanyaan di atas, yaitu:

a. Revisionisme

Tanggapan ini berasal dari Augustinus (354-430) yang menyatakan bahwa etika teologis bertugas untuk merevisi, yaitu mengoreksi dan memperbaiki etika filosofis.

b. Sintesis

Jawaban ini dikemukakan oleh Thomas Aquinas (1225-1274) yang menyintesiskan etika filosofis dan etika teologis sedemikian rupa, hingga kedua jenis etika ini, dengan mempertahankan identitas masing-masing, menjadi suatu entitas baru. Hasilnya adalah etika filosofis 
menjadi lapisan bawah yang bersifat umum, sedangkan etika teologis menjadi lapisan atas yang bersifat khusus.

c. Diaparalelisme

Jawaban ini diberikan oleh F.E.D. Schleiermacher yang menganggap etika teologis dan etika filosofis sebagai gejala-gejala yang sejajar. Hal tersebut dapat diumpamakan seperti sepasang rel kereta api yang sejajar.

Mengenai pandangan-pandangan di atas, ada beberapa keberatan. Mengenai pandangan Augustinus, dapat dilihat dengan jelas bahwa etika filosofis tidak dihormati setingkat dengan etika teologis. Terhadap pandangan Thomas Aquinas, kritik yang dilancarkan juga sama yaitu belum dihormatinya etika filosofis yang setara dengan etika teologis, walaupun kedudukan etika filosofis telah diperkuat. Terakhir, terhadap pandangan Schleiermacher, diberikan kritik bahwa meskipun keduanya telah dianggap setingkat namun belum ada pertemuan di antara mereka.

Ada pendapat lain yang menyatakan perlunya suatu hubungan yang 
dialogis antara keduanya. Dengan hubungan dialogis ini maka relasi keduanya dapat terjalin dan bukan hanya saling menatap dari dua horizon yang paralel saja. Selanjutnya diharapkan dari hubungan yang dialogis ini dapat dicapai suatu tujuan bersama yang mulia, yaitu membantu manusia dalam bagaimana ia seharusnya hidup.

\section{Kekuasaan}

Pada dasarnya, organisasi mempunyai sifat berusaha memenuhi beberapa jenjang keteraturan tertentu sehingga dapat bertahan dan mencapai tujuannya. Ini berarti organisasi harus dapat mengajak anggotanya bersikap dengan cara-cara yang bermanfaat bagi organisasi. Ini dapat meliputi suatu keteraturan (order) yang dirundingkan tetapi pengaturan manusialah yang melibatkan pengaturan kekuasaan. Individu yang bergabung dengan organisasi atau mereka yang dilahirkan ke dalamnya, mencari manfaat tertentu. Dengan kata lain, organisasi memiliki tujuan tertentu dan memiliki sifat untuk selalu dapat memenuhi tujuan tersebut. Usaha-usaha mereka untuk melakukan hal ini adalah dengan menggunakan kekuasaan.

a. Konsep Kekuasaan dan Organisasi 
Kekuasaan adalah kemampuan untuk mempengaruhi, mengatur, atau mengendalikan dan merupakan bagian yang melekat pada proses organisasi. Kekuasaan tidak hanya terletak pada manusia dan sumber daya, tetapi juga dalam struktur sosial itu sendiri.

b. Gagasan Kekuasaan

Ada gagasan tradisional mengenai kekuasaan yang difokuskan pada individu dan pelaksanaan kekuasaannya. Menurut French dan Raven (1959) membagi lima jenis kekuasaan yaitu :

1. Kekuasaan memberi ganjaran (reward power)

Dapatkah A menetapkan ganjaran yang dapat dirasakan oleh B ?

2. Kekuasaan yang memaksa (coercive power)

Dapatkah A memberi sesuatu yang dipandang hukuman kepada $B$ ?

3. Kekuasaan yang sah (legitimate power)

Apakah B percaya bahwa A mempunyai hak untuk mempengaruhi dan $B$ harus menerimanya? Sumber kekuasaan sah mungkin adalah penerimaan suatu struktur sosial atau nilai-nilai budaya.

4. Kekuasaan referen (referent power) 
Apakah B mengenali A? Apakah B ingin seperti $A$ atau mempunyai keinginan merasakan suatu kesatuan dengan $A$ ?

5. Kekuasaan ahli (expert power)

Apakah B percaya bahwa A memiliki pengetahuan atau keahlian khusus yang berguna atau perlu untuk kebaikan B ?

Pandangan mutakhir menyadari bahwa kekuasaan tidak terletak pada manusia semata-mata tetapi dalam struktur sosial yang memungkinkan mereka bertindak. Ini menyatakan bahwa struktur tersebut, atau "aturan mainnya" yang terbentuk secara sosial, memutuskan apa yang dapat dibicarakan dan dengan cara bagaimana. Struktur itu sendiri dapat memutuskan persoalan apa yang mungkin dipertimbangkan dalam proses pengambilan keputusan. Jadi konsep kekuasaan harus mempertimbangkan apa yang dikatakan dan apa yang tidak dikatakan berdasarkan pada struktur sosial yang yang memungkinkan pelaksanaan kekuasaan tersebut. Hal ini disebut "dua wajah kekuasaan".

Kekuasaan terletak dalam struktur itu karena ini merupakan daya pengendali pada mereka yang akan melaksanakan kekuasaan. Individu dapat memliki kemampuan mempengaruhi orang lain berdasarkan suatu 
sumber atau posisi khusus, tetapi kekuasaan meliputi lebih daripada sekadar komoditas atau milik yang dapat digunakan dalam setiap situasi atau struktur sosial. Kekuasaan terletak dalam hubungan antara manusia dan dalam sistem sosial itu sendiri.

c. Interaksi Organisasi/Kekuasaan

Boulding (1989) membagi tiga jenis kekuasaan yang efektif dalam mempertahankan organisasi yaitu:

1. Kekuasaan destruktif (menghancurkan)

Merupakan kekuasaan mengancam dan kemampuan untuk menghancurkan.

2. Kekuasaan produktif (menghasilkan)

Bersifat ekonomik dan meliputi kekuasaan untuk menghasilkan dan menjual.

3. Kekuasaan integratif (menyatukan)

Mendorong kesetiaan, menyatukan orang-orang bersama, dan mampu menggerakkan orang-orang ke arah tujuan bersama.

Namun dari ketiga jenis kekuasaan di atas, yang paling ideal adalah kekuasaan integratif. Boulding menyatakan bahwa kekuasaan integratif adalah bentuk kekuasaan yang paling dominan dan nyata. Dalam hal organisasi, fokus kekuasaan 
terletak pada pengesahan dimana organisasi hierarkis harus mengandalkan informasi dan dukungan dari seluruh strukturnya. Pada dasarnya, organisasi mengembangkan struktur dan peranan yang diciptakan, dipertahankan, dan ditransformasikan melalui proses komunikasi. Selanjutnya, bahasa struktur dan peranan menggambarkan suatu realitas organisasi yang memperoleh pengesahan melalui penggunaannya.

d. Dinamika Komunikasi Organisasi

1. Komunikasi sebagai suatu Mekanisme Kekuasaan

Dalam konteks organisasi, komunikasi digunakan untuk menentukan norma - norma, tujuan, dan perilaku organisasi. Organisasi dapat dipandang sebagai suatu sarana kekuasaan. Manusia memiliki kekuasaan melaksanakannya melalui komunikasi, dan dengan demikian menciptakan tindakan terorganisasi.

2. Komunikasi sebagai Kekuasaan

Kekuasaan dalam organisasi dapat dipandang sebagai kapasitas perorangan untuk membuat perbedaan dalam memproduksi dan mereproduksi struktur (aturan- aturan, kebijakan, praktik- praktik, dan nilai-nilai). Kekuasaan ini dapat berbentuk mengajak orang untuk menaati struktur, menolak struktur, atau terlibat dalam perubahan struktur. Bagian yang paling melekat pada struktur adalah bahasa dan praktik- praktik diskursifnya 
yang mencakup pidato/ ceramah, penulisan dan argumentasi.

3. Komunikasi dan Proses Pemberian Kekuasaan

Konsep

pemberian

kekuasaan atau pemberdayaan (empowerment) memiliki beberapa dimensi. Conger dan Kanungo menyatakan bahwa pemberdayaan dapat ditinjau dari aspek relasional dan motivasional.

a. Aspek relasional menegaskan kepada masalah pembagian kekuasaan antara manager dan bawahan. Ada usaha untuk melonggarkan hirarki dan menekankan pemecahan masalah bersama-sama.

b. Aspek motivasional merujuk pada kebutuhan hakiki pada suatu keyakinan dan kemampuan pribadi. Melalui teknik ini, pegawai merasa memiliki kekuasaan. Jadi memberdayakan dalam arti motivasional di sini adalah mempercayai kemampuan setiap orang yang mencakup kebutuhan dan hak setiap orang untuk merasakan bahwa dirinya mampu berprestasi dan efekif.

Diberdayakan dalam organisasi berarti mengetahui argumentasi yang diterima serta cara-cara yang diterima untuk menggunakanya. Dalam hal ini, berarti kita tidak dapat lepas dari praktek komunikasi dalam organisasi meskipun dalam hal 
ini praktek komunikasi sering diabaikan. Hal yang tidak kalah pentingnya dalam bahasan pemberdayaan adalah masalah pengenalan kondisi yang membangkitkan perasaan tidak berdaya. Dalam organisasi manusia akan merasa tidak berdaya apabila mereka tidak memiliki akses terhadap informasi yang mempengaruhi pekerjaan dan kesejahteraan mereka. Sebagai contoh struktur birokrasi memiliki kondisi yang mengarah pada rasa tidak berdaya. Ambiguitas peranan, harapan terhadap peranan yang berlebihan serta konflik juga merupakan faktor konstektual yang dapat menciptakan ketidakberdayaan.

\section{Politik}

Politik (Yunani: Politikos; Arab: siyasah) (dari bahasa Yunani: politikos, yang berarti dari, untuk, atau yang berkaitan dengan warga negara), adalah proses pembentukan dan pembagian kekuasaan dalam masyarakat yang antara lain berwujud proses pembuatan keputusan, khususnya dalam negara. 1 .1] Pengertian ini merupakan upaya penggabungan antara berbagai definisi yang berbeda mengenai hakikat politik yang dikenal dalam ilmu politik.

Politik adalah seni dan ilmu untuk meraih kekuasaan secara konstitusional maupun nonkonstitusional. Di samping itu politik juga dapat ditilik dari sudut pandang berbeda, yaitu antara lain: 
a. politik adalah usaha yang ditempuh warga negara untuk mewujudkan kebaikan bersama (teori klasik Aristoteles)

b. politik adalah hal yang berkaitan dengan penyelenggaraan pemerintahan dan negara

c. politik merupakan kegiatan yang diarahkan untuk mendapatkan dan mempertahankan kekuasaan di masyarakat

d. politik adalah segala sesuatu tentang proses perumusan dan pelaksanaan kebijakan publik.

Dalam konteks memahami politik perlu dipahami beberapa kunci, antara lain: kekuasaan politik, legitimasi, sistem politik, perilaku politik, partisipasi politik, proses politik, dan juga tidak kalah pentingnya untuk mengetahui seluk beluk tentang partai politik.

Politik berasal dari bahasa Belanda politiek dan bahasa Inggris politics, yang masing-masing

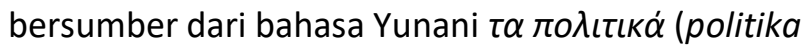
- yang berhubungan dengan negara) dengan akar

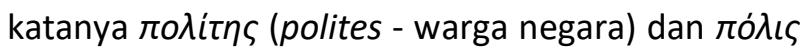
(polis - negara kota). Secara etimologi kata "politik" masih berhubungan dengan politis, kebijakan. Kata "politis" berarti hal-hal yang berhubungan dengan politik. Kata "politisi" berarti orang-orang yang menekuni hal politik. 
Politik berasal dari bahasa Yunani yaitu polis yang berarti kota atau negara kota. Turunan dari kata tersebut yaitu:

a. polites berarti warga negara.

b. politikos berarti kewarganegaraan.

c. politike tehne berarti kemahiran politik.

d. politike episteme berarti ilmu politik.

Kata ini berpengaruh ke wilayah Romawi sehingga bangsa Romawi memiliki istilah ars politica yang berarti kemahiran tentang masalah masalah kenegaraan. Politik pun dikenal dalam bahasa Arab dengan kata siyasah yang berarti mengurus kepentingan seseorang. Pengarang kamus al Muhith mengatakan bahwa sustu arra'iyata siyasatan berarti saya memerintahnya dan melarangnya.

Sedangkan politik secara terminologis dapat diartikan sebagai berikut :

1. Menunjuk kepada satu segi kehidupan manusia bersama dengan masyarakat. Lebih mengarah pada politik sebaga usaha untuk memperoleh kekuasaan, memperbesar atau memperluas serta mempertahankan kekuasaan (politics). Misal: kejahatan politik, kegiatan politik, hak-hak politik.

2. Menujuk kepada "satu rangkaian tujuan yang hendak dicapai" atau "cara-cara atau arah 
kegiatan tertentu untuk mencapai tujuan tertentu". Lebih mengarah pada kebijakan (policy). Misal: politik luar negeri, politik dalam negeri, politik keuangan.

3. Menunjuk pada pengaturan urusan masyarakat dalam segala aspek kehidupan. Pemerintah mengatur urusan masyarakat, masyarakat melakukan koreksi terhadap pemerintah dalam melaksanakan tugasnya (siyasah).

Di antara ketiga definisi tersebut, tentunya definisi pertama lebih memiliki konotasi negatif dibandingkan definisi kedua dan ketiga. Hal ini disebabkan orientasi yang pertama adalah politik kekuasaan, untuk meraih dan mempertahankan kekuasaan dapat dilakukan dalam jalan apapun entah baik entah buruk, dapat menghalalkan segala cara dan lebih berorientasi pada kepentingan pemimpin atau elit yang berkuasa. Sedangkan definisi politik yang kedua dan ketiga lebih berorientasi pada politik pelayanan terhadap masyarakat, dimana posisi pemimpin merupakan pelayan masyarakat bukan penguasa aset-aset strategis.

Teori politik merupakan kajian mengenai konsep penentuan tujuan politik, bagaimana mencapai tujuan tersebut dan segala konsekuensinya. Bahasan dalam Teori Politik antara lain adalah filsafat politik, konsep tentang 
sistem politik, negara, masyarakat, kedaulatan, kekuasaan, legitimasi, lembaga negara, perubahan sosial, pembangunan politik, perbandingan politik, dsb.

Terdapat banyak sekali sistem politik yang dikembangkan oleh negara negara di dunia antara lain: anarkisme,autoritarian, demokrasi, diktatorisme, fasisme, federalisme, feminisme, fundamentalisme keagamaan, globalisme, imperialisme, kapitalisme, komunisme, liberalisme, libertarianisme, marxisme, meritokrasi, monarki, nasionalisme, rasisme, sosialisme, theokrasi, totaliterisme, oligarki dsb.

Secara awam berarti suatu organisasi, tetapi lembaga bisa juga merupakan suatu kebiasaan atau perilaku yang terpola. Perkawinan adalah lembaga sosial, baik yang diakui oleh negara lewat KUA atau Catatan Sipil di Indonesia maupun yang diakui oleh masyarakat saja tanpa pengakuan negara. Dalam konteks ini suatu organisasi juga adalah suatu perilaku yang terpola dengan memberikan jabatan pada orang-orang tertentu untuk menjalankan fungsi tertentu demi pencapaian tujuan bersama, organisasi bisa formal maupun informal. Lembaga politik adalah perilaku politik yang terpola dalam bidang politik.

Pemilihan pejabat, yakni proses penentuan siapa yang akan menduduki jabatan tertentu dan 
kemudian menjalankan fungsi tertentu (sering sebagai pemimpin dalam suatu bidang/masyarakat tertentu) adalah lembaga demokrasi. Bukan lembaga pemilihan umumnya (atau sekarang KPUnya) melainkan seluruh perilaku yang terpola dalam kita mencari dan menentukan siapa yang akan menjadi pemimpin ataupun wakil kita untuk duduk di parlemen.

Persoalan utama dalam negara yang tengah melalui proses transisi menuju demokrasi seperti indonesia saat ini adalah pelembagaan demokrasi. Yaitu bagaimana menjadikan perilaku pengambilan keputusan untuk dan atas nama orang banyak bisa berjalan sesuai dengan normanorma demokrasi, umumnya yang harus diatasi adalah mengubah lembaga feodalistik (perilaku yang terpola secara feodal, bahwa ada kedudukan pasti bagi orang-orang berdasarkan kelahiran atau profesi sebagai bangsawan politik dan yang lain sebagai rakyat biasa) menjadi lembaga yang terbuka dan mencerminkan keinginan orang banyak untuk mendapatkan kesejahteraan.

Untuk melembagakan demokrasi diperlukan hukum dan perundang-undangan dan perangkat struktural yang akan terus mendorong terpolanya perilaku demokratis sampai bisa menjadi pandangan hidup. Karena diyakini bahwa dengan demikian kesejahteraan yang sesungguhnya baru bisa dicapai, saat tiap individu 
terlindungi hak-haknya bahkan dibantu oleh negara untuk bisa teraktualisasikan, saat tiap individu berhubungan dengan individu lain sesuai dengan norma dan hukum yang berlaku.

Ada beberapa konsep politik dasar yang bersumber dari para ahli, yaitu :

1. Klasik. Pada pandangan klasik (Aristoteles) mengemukakan bahwa politik digunakanmasyarakat untuk mencapai suatu kebaikan bersama yang dianggap memilkinilai moral yang lebih tinggi daripada kepentingan swasta. Kepentingan umumsering diartikan sebagai tujuan-tujuan moral atau nilai-nilai ideal yang bersifatabstrak seperti keadilan, kebenaran dan kebahagiaan. Pandangan klasikdianggap kabur seiring banyaknya penafsiran tentang kepentingan umum itusendiri. kepentingan umum dapat diartikan pula sebagai general will, will of all atau kepentingan mayoritas.

2. Kelembagaan. Menurut Max Weber, politik adalah segala sesuatu yang berkaitan denganpenyelenggaraan negara. Max Weber melihat negara dari sudut pandangyuridis formal yang statis. Negara dianggap memiliki hak memonopoli kekuasaan fisik yang utama. Namun konsep ini hanya berlaku bagi negara modern yaitu negara yang sudah ada differensiasi dan spesialisasi peranan,negara 
yang memiliki batas wilayah yang pasti dan penduduknya tidak nomaden.

3. Kekuasaan. Robson mengemukakan politik adalah kegiatan mencari danmempertahankan kekuasaan ataupun menentang pelaksanaan kekuasaan.Kekuasaan sendiri adalah kemampuan seseorang untuk mempengaruhi oranglain, baik pikiran maupun perbuatan agar orang tersebut berfikir dan bertindaksesuai dengan orang yang mempengaruhi.Kelemahan dari konsep ini adalah tidak dapat dibedakannya konsep beraspekpolitik dan yang non politik dan juga kekuasaan hanya salah satu konsepdalam ilmu politik, masih ada konsep ideologi, legitimasi dan konflik.

4. Fungsionalisme. David Easton berpendapat bahwa politik adalah alokasi nilai-nilai secaraotoritatif berdasarkan kewenangan dan mengikat suatu masyarakat.Sedangkan menurut Harold Lasswell, politik merupakan who gets, what gets, when gets dan how gets nilai. Dapat diketahui bahwa politik sebagai perumusan dan pelaksanaan kebijakanumum.Kelemahan dari konsep ini adalah ditempatkannya pemerintah sebagaisarana dan wasit terhadap persaingan diantara pelbagai kekuatan politikuntuk mendapatkan nilai-nilai terbanyak dari kebijakan umum tanpamemperhatikan kepentingan pemerintah itu sendiri. 
5. Konflik. Pandangan konflik mendeskripsikan bahwa politik merupakan kegiatan untukmemengaruhi perumusan dan kebijaksanaan umum dalam rangka usahauntuk memengaruhi, mendapatkan dan mempertahankan nilai. Oleh karenaitu sering terjadi perdebatan dan pertentangan antara pihak yangmemperjuangkan dan pihak yang mempertahankan nilai. Kelemahan konsepini adalah tidak semua konflik berdimensi politik.

\section{Hubungan Internasional}

Dalam bentuk klasiknya hubungan internasional adalah hubungan antar negara, namun dalam perkembangan konsep ini bergeser untuk mencakup semua interaksi yang berlangsung lintas batas negara. Dalam bentuk klasiknya hubungan internasional diperankan hanya oleh para diplomat (dan mata-mata) selain tentara dalam medan peperangan. Sedangkan dalam konsep baru hubungan internasional, berbagai organisasi internasional, perusahaan, organisasi nirlaba, bahkan perorangan bisa menjadi aktor yang berperan penting dalam politik internasional.

Peran perusahaan multinasional seperti Monsanto dalam $\underline{\text { WTO }}$ (World Trade Organization/Organisasi Perdagangan Dunia) misalnya mungkin jauh lebih besar dari peran Republik Indonesia. Transparancy International laporan indeks persepsi 
korupsi-nya di Indonesia mempunyai pengaruh yang besar.

Persatuan Bangsa Bangsa atau PBB merupakan organisasi internasional terpenting, karena hampir seluruh negara di dunia menjadi anggotanya. Dalam periode perang dingin PBB harus mencerminkan realitas politik bipolar sehingga sering tidak bisa membuat keputusan efektif, setelah berakhirnya perang dingin dan realitas politik cenderung menjadi unipolar dengan Amerika Serikat sebagai kekuatan Hiper Power, PBB menjadi relatif lebih efektif untuk melegitimasi suatu tindakan internasional sebagai tindakan multilateral dan bukan tindakan unilateral atau sepihak. Upaya AS untuk mendapatkan dukungan atas inisiatifnya menyerbu Irak dengan melibatkan PBB, merupakan bukti diperlukannya legitimasi multilateralisme yang dilakukan lewat PBB.

Untuk mengatasi berbagai konflik bersenjata yang kerap meletus dengan cepat di berbagai belahan dunia misalnya, saat ini sudah ada usulan untuk membuat pasukan perdamaian dunia (peace keeping force) yang bersifat tetap dan berada di bawah komando PBB. Hal ini diharapkan bisa mempercepat reaksi PBB dalam mengatasi berbagai konflik bersenjata. Saat misalnya PBB telah memiliki semacam polisi tetap yang setiap saat bisa dikerahkan oleh Sekertaris Jenderal PBB untuk beroperasi di daerah operasi PBB. Polisi PBB ini yang menjadi Civpol (Civilian Police/polisi sipil) pertama saat Timor Timur lepas dari Republik Indonesia. 
Hubungan internasional telah bergeser jauh dari dunia eksklusif para diplomat dengan segala protokol dan keteraturannya, ke arah kerumitan dengan kemungkinan setiap orang bisa menjadi aktor dan memengaruhi jalannya politik baik di tingkat global maupun lokal. Pada sisi lain juga terlihat kemungkinan munculnya pemerintahan dunia dalam bentuk PBB, yang mengarahkan pada keteraturan suatu negara (konfederasi?).

\section{a. Masyarakat}

adalah sekumpulan orang orang yang mendiami wilayah suatu negara.

\section{b. Kekuasaan}

Dalam teori politik menunjuk pada kemampuan untuk membuat orang lain melakukan sesuatu yang tidak dikehendakinya. Max Weber menuliskan adanya tiga sumber kekuasaan: pertama dari perundangundangan yakni kewenangan; kedua, dari kekerasan seperti penguasaan senjata; ketiga, dari karisma.

\section{c. Negara}

negara merupakan suatu kawasan teritorial yang didalamnya terdapat sejumlah penduduk yang mendiaminya, dan memiliki kedaulatan untuk menjalankan pemerintahan, dan keberadaannya 
diakui oleh negara lain. ketentuan yang tersebut diatas merupakan syarat berdirinya suatu negara menurut konferensi Montevideo pada tahun 1933

\section{d. Tokoh dan pemikir ilmu politik}

Tokoh tokoh pemikir Ilmu Politik dari kalangan teoris klasik, modern maupun kontempoter antara lain adalah: Aristoteles, Adam Smith, Cicero, Friedrich Engels, Immanuel Kant, John Locke, Karl Marx, Lenin, Martin Luther, Max Weber, Nicolo Machiavelli, Rousseau, Samuel P Huntington, Thomas Hobbes, Antonio Gramsci, Harold Crouch, Douglas E Ramage. Beberapa tokoh pemikir dan penulis materi IImu Politik dan Hubungan Internasional dari Indonesia adalah: Miriam Budiharjo, Salim Said dan Ramlan Surbakti.

\section{e. Perilaku politik}

Perilaku politik atau (Inggris: Politic Behaviour)adalah perilaku yang dilakukan oleh insan/individu atau kelompok guna memenuhi hak dan kewajibannya sebagai insan politik. Seorang individu/kelompok diwajibkan oleh negara untuk melakukan hak dan kewajibannya guna melakukan perilaku politik adapun yang dimaksud dengan perilaku politik contohnya adalah: (Briones \& Cabrera, 2016) 
1. Melakukan pemilihan untuk memilih wakil rakyat / pemimpin

2. Mengikuti dan berhak menjadi insan politik yang mengikuti suatu partai politik atau parpol , mengikuti ormas atau organisasi masyarakat atau Ism lembaga swadaya masyarakat

3. Ikut serta dalam pesta politik

4. Ikut mengkritik atau menurunkan para pelaku politik yang berotoritas

5. Berhak untuk menjadi pimpinan politik

6. Berkewajiban untuk melakukan hak dan kewajibannya sebagai insan politik guna melakukan perilaku politik yang telah disusun secara baik oleh undang-undang dasar dan perundangan hukum yang berlaku 


\section{BAB 9}

\section{Negoisasi}

\section{A. Jenis-Jenis Negoisasi}

\section{Pengertian Negosiasi}

Negosiasi menurut Kamus Besar Bahasa Indonesia (KBBI) adalah proses tawar menawar dengan jalan berunding untuk memberi atau menerima guna mencapai kesepakatan bersama antara satu pihak dengan pihak lainnya. Ada juga yang berpendapat bahwa Negosiasi adalah proses perundingan dua belah pihak atau lebih yang masing-masing memiliki sesuatu yang dibutuhkan oleh pihak lainnya untuk mencapai kesepakatan yang saling menguntungkan. Selanjutnya Negosiasi adalah suatu cara untuk menetapkan keputusan yang dapat disepakati dan diterima oleh dua pihak dan menyetujui apa dan bagaimana tindakan yang akan dilakukan dimasa mendatang. Lainnya, Negosiasi adalah proses pertukaran barang atau jasa 
antara dua pihak atau lebih, dan masing-masing pihak berupaya untuk menyepakati tingkat harga yang sesuai untuk proses pertukaran tersebut. Dalam komunikasi bisnis, Negosiasi adalah suatu proses dimana dua pihak atau lebih yang mempunyai kepentingan yang sama atau bertentangan, bertemu dan berbicara untuk mencapai suatu kesepakatan. Perbedaan kepentingan memberikan alasan terjadinya suatu titik temu dan dasar motivasi untuk mencapai kesepakatan baru.

2. Jenis - jenis negosiasi

\section{a. Negosiasi Berdasarkan Situasi}

\section{Negosiasi Formal}

Negosiasi formal merupakan negosiasi yang terjado dalam situasi formal. Ciri-ciri negosiasi formal adalah adanya perjanjian atau hitam di atas putih yang sah secara hukum. Oleh karena itu, pelanggaran terhadap perjanjian yang telah disepakati dapat diperkarakan ke ranah hukum. Contoh negosiasi formal adalah negosiasi antar dua perusahaan.

\section{Negosiasi Non Formal atau Informal}

Dalam kehidupan sehari-hari, manusia sering bernegosiasi. Negosiasi dapat terjadi kapan saja, dimana saja, dan dengan siapa saja. Misalnya negosiasi antara ayah dan anak. Negosiasi ini tidak membutuhkan perjanjian khusus yang melibatkan hukum. 
b. Negosiasi Berdasarkan Jumlah Negosiator

1. Negosiasi dengan Pihak Penengah

Negosiasi dilakukan oleh dua negosiator atau lebih dan pihak penengah. Negosiator saling memberikan argumentasi. Pihak penengah bertgas memberikan keputusn akhir dalam negosiasi tersebut. Contoh negosiasi jenis ini adalah sidang di pengadilan. Pihak penggugat dan tergugat adalah pihak yang bernegosiasi. Hakim berperan sebagai pihak penengah.

\section{Negosiasi tanpa Pihak Pengengah}

Negosiasi dilakikan oleh dua negosiator atau lebih. Negosiasi dilakukan tanpa pihak penengah, sehingga keputusan negosiasi tergantung pada pihak yang bernegosiasi. Salah satu contoh negosiasi jenis ini adalah negosiasi antara perwakilan OSIS dan pihak sponsor.

\section{c. Negosiasi Berdasarkan Untung Rugi}

\section{Negosiasi Kolaborasi (win-win)}

Dalam negosiasi kolaborasi, para negosiator berusaha mencapai kesepakatan dengan menggabungkan kepentingan masingmasing.

2. Negosiasi Dominasi (win-lose) 
Dalam negosiasi ini, negosiator mendapatkan keuntungan besar dari kesepakatan yang dicapai. Sementara itu, pihak lawan negosiasi mendapat keuntungan lebih kecil.

3. Negosiasi Akomodasi (lose-win)

Dalam negosiasi akomodasi, negosiator mendapatkan keuntungan sangat kecil bahkan kerugian. Sementara itu, pihak lawan negosiasi mendapat keuntungan sangat besar bahkan memperoleh $100 \%$ keuntungan. Kerugian ini dikarenakan kegagalan negosiator dalam bernegosiasi sehingga tidak memperoleh keuntungan

4. Negosiasi Menghindari Konflik (lose-lose)

Dalam negosiasi ini, kedua pihak menghindari konflik yang muncul. Akibatnya, kedua pihak tidak bersepakat untuk menyelesaikan konnflik.

\section{Tujuan Negosiasi}

a. Untuk menyatukan perbedaan-perbedaan pendapat dari orang-orang yang memiliki kepentingan yang berbeda, 
b. Untuk mendapatkan atau mencapai kata kesepakatan dalam kesamaan persepsi, saling pengertian, dan persetujuan.

c. Untuk mendapatkan kondisi penyelesaian atau jalan keluar dari masalah yang dihadapi

\section{Manfaat Negosiasi}

Manfaatnya yaitu untuk menciptakan jalinan kerja sama antara badan usaha, institusi ataupun perorangan dalam melakukan suatu kegiatan dan usaha bersama atas dasar saling pengertian.

\section{Struktur Negosiasi (UMUM)}

\section{a. Struktur Negosiasi (UMUM)}

1. Negosiator: Penutur\&Mitra Tutur

2. Pembuka : Penggiringan topik / basa-basi

3. Isi : Inti pembicaraan

4. Penutup : Pengambilan keputusan / penyelesaian

\section{b. Struktur Negosiasi (KOMPLEKS)}

a. Orientasi : Kalimat pembuka, biasanya dibubuhi salam. Fungsinya memulai negosiasi

b. Permintaan : Suatu hal berupa barang ataupun jasa yang ingin diblei oleh pembeli atau konsumen

c. Pemenuhan : Pemenuhan hal berupa barang atau jasa dari pemberi jasa atau penjual yang diminta oleh pembeli atau konsumen

d. Penawaran : Puncaknya Negosiasi terjadi tawar menawar 
e. Persetujuan : Keputusan antara dua belah pihak untuk penawaran yang sudah dilakukan

f. Pembelian : Keputusan konsumen jadi menerima/menyetujui penawaran itu atau tidak

g. Penutup : Kalimat penutup atau salam penutup

6. Ciri Umum Negosiasi

1. Menghasilkan Kesepakatan

2. Menghasilkan Keputusan yang saling menguntungkan

3. Memprioritaskan Kepentingan Bersama

4. Merupakan sarana untuk mencari penyelesaian

5. Mengarah pada tujuan praktis

7. Ciri Kebahasaan Teks Negosiasi

1. Menggunakan bahasa yang santun

2. Terdapat ungkapan persuasif ( Bahasa untuk membujuk )

3. Berisi pasangan tuturan

4. Keputusan atau kesepakatan yang dihasilkan tidak merugikan dua belah pihak

5. Bersifat memerintah dan memenuhi perintah

\section{Cara Agar Negosiasi Berjalan Lancar}

a. Mengajak untuk membuat kesepakatan

b. Memberikan alasan mengapa harus ada kesepakatan 
C. Membandingkan beberapa pilihan

d. Memperjelas dan menguji pandangan yang dikemukakan

e. Mengevaluasi kekuatan dan komitmen bersama

f. Menetapkan dan menegaskan kembali tujuan negosiasi

\section{Cara Negosiasi}

a. Anda harus bernegosiasi apapun dan segalanya

b. Anda harus menunjukkan kejujuran dalam proses negosiasi

C. Jangan terburu-buru dalam negosiasi

d. Cari tahu sebanyak mungkin informasi mengenai produk dan penjual

e. Berikan harga maksimal dan sopan

f. Anda harus menghindari ikatan emosional dengan apa yang anda jual atau beli

\section{B. Cara Peningkatan Proses Negoisasi}

\section{a. Cara Menetapkan Keputusan}

Negosiator yang baik hendaknya membangun kerangka dasar yang penting tentang negosiasi yang akan dilakukan, agar berhasil menjalankan tugasnya dengan baik. Negosiasi adalah cara untuk menetapkan keputusan yang dapat disepakati dan diterima beberapa pihak dan menyetujui bagaimana tindakan 
yang akan dilakukan. Ujung dari negosiasi adalah poin kesepakatan yang diambil kedua belah pihak. Negosiasi berpotensi untuk terjadinya konflik mulai awal hingga akhir pembicaraan. Negosiasi dapat menggunakan cara-cara pertukaran sesuatu baik berupa barter ataupun bargaining. Umumnya negosiasi dilakukan hampir selalu berbentuk tatap-muka, menggunakan bahasa lisan, gerak/bahasa tubuh maupun ekspresi wajah.

Ada tiga konsep penting yang harus dipahami oleh seorang negosiator, untuk membangun kerangka dasar pengambilan keputusan, yaitu :

a. Best Alternative to a Negotiated Agreement (BATNA), adalah langkah-langkah atau alternatifalternatif yang akan dilakukan oleh seorang negosiator bila negosiasi tidak mencapai kesepakatan. Misalnya mengenai pesangon yang akan dibayarkan oleh pengusaha dalam proses PHK tidak dapat disepakati oleh pihak pekerja, maka ada dua pilihan yang bisa ditawarkan oleh pihak pengusaha yaitu mencoba untuk melakukan trade off dengan pasal penambahan cuti atau meninggalkan perundingan bila tidak ada tandatanda positif dari pihak pekerja untuk beranjak dari posisinya saat itu.

b. Reservation price, yaitu nilai atau tawaran terendah yang dapat diterima sebagai sebuah kesepakatan dalam negosiasi. Sebagai contoh : Negosiator dari pihak pekerja akan menyepakati 
hasil perundingan secara keseluruhan, apabila minimum 5 dari 10 usulan mereka dapat diterima oleh pihak perusahaan.

c. Zone of Possible Agreement atau disingkat ZOPA, yaitu suatu zona atau area yang memungkinkan terjadinya kesepakatan dalam proses negosiasi.

\section{BAB 10}

\section{Pengambilan Keputusan}

\section{A. Jenis-Jenis Pengambilan Keputusan}

\section{Pengertian}

Keputusan adalah suatu pemutusan atau pengakhiran dari pada suatu proses pemikiran tentang suatu masalah atau problem, untuk menjawab pertanyaan apa yang harus diperbuat guna mengatasi masalah tersebut, dengan menjadikan pilihan pada salah satu alternatif tertentu. Pengambilan keputusan dibutuhkan jika memiliki masalah yang harus diselesaikan dengan memuaskan. Situasi masalah tersebut yang menjadi masukan pertama dalam sistem pembuatan keputusan.

Beberapa pengertian tentang pengambila keputusan menurut beberapa pakar : 
1. Menurut Wiranda (1990), pengambilan keputusan merupakan salah satu peranan manajer yang disebut peranan decisional.

2. Menurut Sutisna (1985), suatu putusan ialah proses memilih tindakan tertentu antara sejumlah tindakan alternative yang mungkin.

3. Menurut Drummond (1985), pengambilan keputusan merupakan usaha penciptaan kejadiankejadiandan pembentukan masa depan (peristiwaperistiwa pada saat pemilihan dan sesudahnya).

Pengambilan keputusan (decision making) memegang peranan penting karena keputusan yang diambil oleh manajer merupakan hasil pemikiran akhir yang harus dilaksanakan oleh bawahannya atau organisasi yang ia pimpin. Ada keputusan yang tidak terlalu berpengaruh terhadap organisasi, tetapi ada keputusan yang dapat menentukan kelangsungan hidup organisasi. Oleh karena itu, hendaknya mengambil keputusan dengan hati-hati dan bijaksana. Sehingga dapat disimpulkan dari definisi diatas bahwa pengambilan keputusan ialah proses pemecahan masalah dengan menentukan pilihan dari beberapa alternative untuk menetapkan suatu tindakan dalam mencapai tujuan yang diinginkan.

\section{Jenis-jenis keputusan organisasi}

Jenis keputusan dalam sebuah organisasi dapat digolongkan berdasarkan banyaknya waktu yang diperlukan untuk mengambil keputusan tersebut. 
Bagian mana organisasi harus dilibatkan dalam mengambil keputusan, dan pada bagian organisasi mana keputusan tersebut difokuskan. Secara garis besar, keputusan digolongkan ke dalam keputusan rutin dan keputusan yang tidak rutin. keputusan rutin adalah keputusan yang sifatnya rutin dan berulang-ulang, dan biasanya telah dikembangkan cara tertentu untuk mengendalikannya. Keputusan tidak rutin adalah keputusan yang diambil pada saat-saat khusus dan tidak bersifat rutin.

Di sisi lain, ada pula pembagian jenis keputusan berdasarkan pihak pengambil keputusan, yaitu:

1. Keputusan strategis

Setiap organisasi melahirkan berbagai kebijakan atau keputusan organisasional. Kebijakan dan arah organisasi merupakan keputusan strategis. Kebijakan dan arah yang dimaksud adalah keputusan-keputusan apasaja yang telah diambil dalam organisasi yang membawa organisasi tersebut mencapai arah tujuan bersama dalam organisasi.

2. Keputusan operasional

Adapun keputusan organisasional menyangkut pengelolaan organisasi sehari-hari. Keputusan operasional sangat menentukan efektivitas keputusan strategis yang dimabil oleh 
para manajer puncak (Drummond, 1995). Keputusan operasional ini dilakukan untuk menjalankan kegiatan organisasi sehari-hari atau dilakukan dalam rutinitas organisasi demi berjalannya organisasi tersebut.

Ada pula jenis keputusan yang berdasarkan masalah yang dihadapi, yaitu:

1. Keputusan yang diprogramkan (program decision)

Keputusan ini merupakan keputusan yang berulang dan telah ditentukan sebelumnya, dalam keputusan terprogram prosedur dapat digunakan untuk menyelesaikan permasalahan yang dialami organisasi. Keputusan terprogram memiliki struktur yang baik karena pada umumnya kriteria bagaimana suatu kinerja diukur sudah jelas, informasi mengenai kinerja saat ini tersedia dengan baik, terdapat banyak alternatif keputusan, dan tingkat kepastian relatif yang tinggi. Tingkat kepastian relatif adalah perbandingan tingkat keberberhasilan antara 2 alternatif atau lebih. Keputusan ini merupakan keputusan yang baik karena tedapat langkah-langkah pengambilan keputusan yang tertata sehingga dapat memudahkan dalam pengambilan keputusan.

2. Keputusan yang tidak diprogramkan (non-programmed decision) 
Keputusan ini belum ditetapkan sebelumnya dan pada keputusan tidak terprogram tidak ada prosedur baku yang dapat digunakan untuk menyelesaikan permasalahan. Keputusan ini dilakukan ketika organisasi menemui masalah yang belum pernah mereka alami sebelumnya, sehingga organisasi tidak dapat memutuskan bagaimana merespon permasalahan tersebut, sehingga terdapat ketidakpastian apakah solusi yang diputuskan dapat menyelesaikan permasalahan atau tidak, akibatnya keputusan tidak terprogram menghasilkan lebih sedikit alternatif keputusan dibandingkan dengan keputusan terprogram selain itu tingginya kompleksitas dan ketidakpastian keputusan tidak terprogram pada umumnya melibatkan perencanaan strategik. Jadi keputusan ini muncul dikarenakan adanya masalah baru yang belum pernah terjadi atau belum terdapat pengalaman terhadap masalah tersebut.

Ada pula jenis keputusan yang berdasarkan gaya pengambilan keputusan, yaitu:

1. Gaya direktif

Pembuat keputusan gaya direktif mempunyai toleransi rendah pada ambiguitas, dan berorientasi pada tugas dan masalah teknis. Pembuat keputusan ini cenderung lebih efisien, logis, pragmatis dan sistematis dalam memecahkan masalah. Pembuat keputusan direktif juga berfokus pada fakta dan menyelesaikan segala sesuatu dengan cepat. Mereka berorientasi pada 
tindakan, cenderung mempunyai fokus jangka pendek, suka menggunakan kekuasaan, ingin mengontrol, dan segan menampilkan gaya kepemimpinan otokratis. Keputusan ini diambil dengan tujuan menyelesaikan masalah secepat mungkin dan seefektif mungkin dan cenderung berlangsung dalam jangka pendek.

2. Gaya analitik

Pembuat keputusan gaya analitik mempunyai toleransi yang tinggi untuk ambiguitas dan tugas yang kuat serta orientasi teknis. Jenis ini suka menganalisis situasi pada kenyataannya, mereka cenderung terlalu menganalisis sesuatu. Mereka mengevaluasi lebih banyak informasi dan alternatif darpada pembuat keputusan direktif. Mereka juga memerlukan waktu lama untuk mengambil kepuputusan mereka merespons situasi baru atau tidak menentu dengan baik. Mereka juga cenderung mempunyai gaya kepemimpinan otokratis. Keputusan dengan gaya ini diambil dengan sebelumnya menganalisis informasi yang ada mengenai masalah tersebut secara mendalam supaya keputusan yang akan diambil tepat walaupun dalam proses analisisnya membutuhkan waktu yang cukup lama untuk mendapatkan hasil yang maksimal.

3. Gaya konseptual

Pembuat keputusan gaya konseptual mempunyai toleransi tinggi untuk ambiguitas, orang yang kuat dan peduli pada lingkungan sosial. Mereka 
berpandangan luas dalam memecahkan masalah dan suka mempertimbangkan banyak pilihan dan kemungkinan masa mendatang. Pembuat keputusan ini membahas sesuatu dengan orang sebanyak mungkin untuk mendapat sejumlah informasi dan kemudian mengandalkan intuisi dalam mengambil keputusan. Pembuat keputusan konseptual juga berani mengambil risiko dan cenderung bagus dalam menemukan solusi yang kreatif atas masalah. Akan tetapi, pada saat bersamaan, mereka dapat membantu mengembangkan pendekatan idealistis dan ketidakpastian dalam pengambilan keputusan. Dalam keputusan ini tersedia banyak pilihan keputusan yang dapat diambil sehingga memudahkan proses pengambilan keputusan.

4. Gaya perilaku

Pembuat keputusan gaya perilaku ditandai dengan toleransi ambiguitas yang rendah, orang yang kuat dan peduli lingkungan sosial. Pembuat keputusan cenderung bekerja dengan baik dengan orang lain dan menyukai situasi keterbukaan dalam pertukaran pendapat. Mereka cenderung menerima saran, sportif dan bersahabat, dan menyukai informasi verbal daripada tulisan. Mereka cenderung menghindari konflik dan sepenuhnya peduli dengan kebahagiaan orang lain. Akibatnya, pembuat keputusan mempunyai kesulitan untuk berkata 'tidak' kepada orang lain, dan mereka tidak membuat keputusan yang tegas, terutama saat hasil keputusan akan membuat orang 
sedih. Pada keputusan ini menitik beratkan pengambilan keputusan dengan perasaan dimana keputusan ini menghormati berbagai aspirasi yang ada dalam proses pengambilan keputusan.

\section{B. Proses Pengambilan Keputusan}

Proses pengambilan keputusan terdiri dari 3 tahap yaitu penemuan masalah, pemecahan masalah dan pengambilan keputusan.

1. Penemuan masalah

Tahap ini merupakan tahap untuk mendefinisikan masalah dengan jelas, sehingga perbedaan antara masalah dan bukan bukan masalah ( misalnya isu) menjadi jelas. Sehingga masalah yang dihadapi dapat di cari model dan jalan keluar yang sesuai.

2. Pemecahan Masalah

Tahap ini merupakan tahap penyelesaian terhadap masalah yang sudah ada atau sudah jelas. Langkah-langkah yang diambil adalah sebagai berikut :

a. Identifikasi alternatif-alternatif keputusan untuk memecahkan masalah

b. Perhitungan mengenai faktor-faktor yang tidak dapat diketahui sebelumnya atau di luar jangkauan manusia, identifikasi peristiwa-peristiwa di masa datang (state of nature). 
c. Pembuatan alat (sarana) untuk mengevaluasi atau mengukur hasil, biasanya berbentuk tabel hasil (pay off table)

d. Pemilihan dan penggunaan model pengambilan keputusan.

3. Pengambilan keputusan

Keputusan yang diambil adalah berdasarkan pada keadaan lingkungan atau kondisi yang ada, seperti kondisi pasti, kondisi beresiko, kondisi tidak pasti, dan kondisi konflik.

Beberapa pendapat mengenai proses pengambilan keputusan yang dikemukakan oleh :

a. Herbert A. Simon

Menurut Herbert A. Simon proses pengamblan keputusan dibagi menjadi 3 fase yaitu

1. Fase Intelijensia

Fase ini merupakan informasi untuk keadaan yang memungkinkan dalam rangka pengambilan keputusan

2. Fase Disain

Fase ini merupakan kegiatan perencanaan dalam pengambilan dari keputusan terdiri dari :

a. Identifikasi masalah

b. Formulasi masalah 
3. Fase Pemilihan

Fase ini merupakan fase seleksi alternatif atau tindakan.

b. Menurut Richard I. Levin

Menurut Richard I. Levin proses pengambilan keputusan terdiri dari 6 tahap yaitu :

1. Observasi

Tahap ini berupa (aktifitas proses) kunjungan lapangan, konprensi, observasi, dan riset yang dapat menjadi informasi dan data penunjang

2. Analisis dan pengenalan masalah

Tahap ini dapat berupa (aktivitas proses) penentuan penggunaan, penentuan tujuan, dan penentuan batasan-batasan yang dapat menjadi pedoman atau petunjuki yang jelas untuk mencari pemecahan yang dibutuhkan.

3. Pengembangan Model

Tahap ini dapat berupa (aktivitas proses) peralatan pengambilan keputusan antar hubungan 
model matematik, riset yang dapat menjadi (output proses) model yang berfungsi di bawah batasan lingkungan yang telah ditetapkan.

4. Memilih data masukan yang sesuai

Tahap ini dapat berupa data internal dan ekternal, kenyataan, pendapat, serta data bank computer yang dapat menjadi (output process) input yang memadai untuk mengerjakan dan menguji model yang digunakan.

5. Perumusan dan pengetesan yang dapat dipertanggungjawabkan

Tahap ini berupa pengujian, batasan, dan pembuktian yang dapat menjadi pemecahan yang membantu pencapaian tujuan.

6. Penerapan Pemecahan

Tahap ini berupa pembahasan perilaku, pelontaran ide, pelibatan manajemen, serta penjelasan yang menjadi pemahaman manajemen untuk menunjang model operasi dalam jangka yang lebih panjang.

c. Menurut Sir Francis Bacon

Menurut Sir Francis Bacon proses pengambilan keputusan terdiri dari 6 tahap yaitu :

1. Merumuskan/mendefinisikan masalah

Tahap ini merupakan usaha untuk mencari permasalahan yang sebenarnya 
2. Pengumpulan informasi yang relevan

Tahap ini merupakan pencarian faktor-faktor yang mungkin terjadi sehingga dapat diketahui penyebab timbulnya masalah.

3. Mencari alternatif tindakan

Tahap ini merupakan pencarian kemungkinan yang dapat ditempuh berdasarkan data dan permasalahan yang ada.

4. Analisis Alternatif

Tahap ini merupakan analisis terhadap setiap alternative menurut krietria tertentu yang sifatnya kualitatif dan kuantitatif

5. Memilih alternatif terbaik

Tahap ini merupakan pemilihan alternative terbaik yang dilakukan atas kriteria dan skala prioritas tertentu

6. Melaksanakan keputusan dan evaluasi hasi;

Tahap ini merupakan tahap pelaksanaan dan pengambilan tindakan. Umumnya tindakan ini dituangkan ke dalam rencana tindakan. Evaluasi hasil memberikan masukan/umpan balik yang berguna untuk memperbaiki suatu keptusan atau mangubah tujuan semula karena telah terjadi perubahanperubahan.

d. Prof. Dr. Mr. S. Prajudi Atmosudirjo 
Menurut Prof. Dr. Mr. S Prajudi Atmosudirjo proses pengambilan keputusan terdiri dari 5 tahap yaitu :

1. Seseorang mula-mula harus menyadari dan menempatkan diri sebagai pimpinan dalam organisasi dan bertanggung jawab sebagai pimpinan organisasi serta harus memutuskan sesuatu jika dalam organisasi tersebut muncul masalah

2. Masalah yang dihadapi, terlebih dahulu harus ditelaah, mengingat masalah tersebut memiliki macam-macam sifat, bentuk dan kompleksitasnya.

3. Setelah ditelaah, kemudian harus dianalisis situasi yang mempengaruhi organisasi dan masalahnya.

4. Menelaah keputusan yang dibuatnya, terutama yang ditelaah adalah alternatif-alternatif yang dikemukakan dengan konsekuensi masing-masing untuk kemudian dipilih satu di antara alternative-alternatif tersebut yang dianggap paling tepat.

5. Setelah keputusan diambil, kemudian keputusan itu dilaksanakan. Keberhasilannya tergantung pada jiwa dan manajemen dari kepemimpinan.

C. Pengaruh Perilaku Dalam Pengambilan Keputusan

Pengambilan keputusan (desicion making) merupakan tindakan untuk melakukan penilaian dan menjatuhkan pilihan dari beberapa alternatif yang ada. G. R. Terry mengemukakan bahwa pengambilan keputusan adalah sebagai pemilihan yang didasarkan pada kriteria tertentu atas dua atau lebih alternatif yang mungkin. 
Herbert A. Simon, ahli teori keputusan dan organisasi mengonseptualisasikan tiga tahap utama dalam proses pengambilan keputusan, sebagai berikut:

1. Aktivitas inteligensi, berasal dari pengertian militer "intelligence," Simon mendeskripsikan tahap awal ini sebagai penelusuran kondisi lingkungan yang memerlukan pengambilan keputusan

2. Aktivitas desain, tahap ini terjadi tindakan penemuan, pengembangan, dan analisis masalah

3. Aktivitas memilih, tahap ini merupakan tindakan untuk memilih tindakan/alternatif tertentu dari yang tersedia.

Teori pengambilan keputusan klasik berjalan dalam asumsi rasionalitas dan kepastian, tetapi tidak begitu halnya dengan teori keputusan perilaku. Ahli teori perilaku pengambilan keputusan berpendapat bahwa individu mempunyai keterbatasan kognitif. Menurut Driscoll (1978), partisipasi dalam pengambilan keputusan berhubungan dengan efficacy. Efficacy sendiri didefinisikan sebagai perasaan atau anggapan bahwa seseorang mampu untuk mempengaruhi pembuatan keputusan dalam organisasi. Partisipasi seorang individu dalam proses pengambilan keputusan yang tinggi apabila ia memiliki efficacy yang tinggi, ia memiliki keyakinan bahwa ia bisa ikut mempengaruhi sistem, proses, dan isi dari keputusan yang dibuat. Begitu pula sebaliknya, apabila seorang individu memiliki efficacy yang rendah ia cenderung akan kurang berpartisipasi. Hal ini disebabkan ia memiliki anggapan bahwa dirinya tidak bisa mempengarui sistem, proses dan isi dari sebuah keputusan. 


\section{DAFTAR PUSTAKA}

Ardiprawiro, S. . (2013). Teori Organisasi Umum 2: Bab 3 Pengambilan Keputusan dalam.

Briones, J. P., \& Cabrera, D. P. (2016). INTERNET FINANCIAL REPORTING: THE CASE OF PHILIPPINE BANKS Jesus P. Briones Doringer P. Cabrera University of Batangas, Philippines, 13(1), 1-18.

Budiyono. (2009). Sosiologi 2 untuk SMA/MA XI. Jakarta: Pusat Perbukuan Departemen Pendidikan Nasional.

Dale, M. (2003). Developing Management Skill (Terjemahan). Jakarta: PT. Gramedia.

Djatmiko, Y. H. (2008). Perilaku Organisasi. Bandung: Alfabeta. Definisi Strategi. (2011). Retrieved from http://definisimu.blogspot.com/2012/11/definisistrategi.html

Etika. (n.d.). Retrieved from https://id.wikipedia.org/wiki/Etika Gitosudarmo, I., Chons, M. C., \& Sudita, I. N. (2000). Perilaku Keorganisasian (1st ed.). Yogyakarta: BPFE.

Judge., S. P. R. dan T. A. (2015). Prilaku Organisasi. Bandung: 
Alfabeta.

Majalah Eksekutif. (1987, February). Majalah Eksekutif.

Luthans Fred. (2005). Perilaku Organisasi (10th ed.). Yogyakarta: Andi.

Prof. Dr. Nana Syaodih Sukmadinata. (2007). Landasan Psikologi Proses Pendidikan. Bandung: Rosda Karya.

Prof. Dr. Sofyan S. Willis. (2013). Psikologi Pendidikan. Bandung: Alfabeta.

Pujangkoro, S. A. (2004). Analisis Jabatan (Job Analysis). Jurnal Jurusan Teknik Industri Fakultas Teknik Universitas Sumatera Utara.

Rachman, A. Modul III Etika Humas. Pusat Pengambangan Bahan Ajar UMB.

Robbins, S., \& Judge, T. A. (n.d.). Perilaku Organisasi (12th ed.). Jakarta: Salemba Empat.

Saptono, \& S, B. S. (2016). Sosiologi. Jakarta: PHiBETA.

Sedarmayanti. (2011). Manajemen Sumber Daya Manusia. Bandung: PT Reflika Aditama.

Sopiah. (2008). Perilaku Organisasional. Penerbit CV Andi Offset: CV Andi Offset.

Sutrisno, E. (2010). Manajemen Sumber Daya Manusia. Jakarta: Kencana.

Wrahatnala, B. (2009). Sosiologi 2 untuk SMA dan MA kelas XI. Jakarta: Pusat Perbukuan Departemen Pendidikan Nasional.

Ariesca, V. (2014). "Pentingnya Motivasi dalam Organisasi." Retrieved from http://vickyariesca.blogspot.com/2012/01/pentingnyamotivasi-dalam organisasi.html, pada tanggal 18 Maret 2014 pukul 21.35

Atribusi. Retrieved from https://pakarkomunikasi.com/teoriatribusi

Evaluasi Kinerja Organisasi. (2012). Retrieved from 
https://alisadikinwear.wordpress.com/2012/05/13/evaluasikinerja-organisasi/

Jenis negosiasi.

(2016).

Retrieved from

http://yayanxtpm1.blogspot.com/2016/03/negosiasipengertian-jenis-ciri-tujuan.html

Marina, A. (2009). "Teori Motivasi Kepuasan",. Retrieved from http://forestgama.blogspot.com/2009/02/teori-motivasikepuasan.html, pada tanggal 13 Mei 2014 pukul 14.52 Nurhasanah. (2014). "Motivasi." Retrieved from http://nurhasanahsanah.blogspot.com/2013/11/motivasi, pada tanggal 26 Maret 2014 pukul 15.15

Pace, R. W. (1998). Komunikasi Organisasi Strategi Meningkatkan Kinerja Perusahaan (alih bahasa). Bandung: Rosda Karya.

Pemberdayaan. (2013).pemberdayaan dalam organisasi. (2018).

Retrieved from

https://www. wartatransparansi.com/2018/10/15/pemberda yaan-dalam-organisasi.html

Pengertian dan Karakteristik Kelompok. (2013). Retrieved from http://kiranaketty.blogspot.com/2013/04/pengertian-dankarakteristik-kelompok.html

Pengertian Perilaku. Retrieved from http://www.definisipengertian.com/2015/07/definisi-pengertian-perilaku$\underline{\text { menurut-ahli.html }}$

Pengertian Umpan Balik. (2016). Retrieved from https://www.coursehero.com/file/18741708/PengertianUmpan-Balik/

Penghargaan dan Hukuman. (2014). Retrieved from http://coghy.blogspot.com/2014/11/artikel-penghargaandan-hukuman-dalam.html

Perilaku Kerja. Retrieved from

http://riccabelajarpsikologi.blogspot.com/2010/10/workingbehaviour-perilaku-kerja.html?m=1 
Persepsi.

(2011).

Retrieved

from

http://kajianpsikologi.blogspot.com/2011/01/persepsi.html

Perilaku

Individu.

Retrieved

from

http://rizkiafandi.blogspot.com/2012/03/penjelasan-

mengenai-perilaku-individu.html

pengaruh perilaku individu. (2016). Retrieved from

http://ivotreswono.blogspot.com/2016/02/pengaruh-

perilaku-individu-dalam.html

Proses Pengambilan Keputusan. (2014). Retrieved from http://privateselv.blogspot.com/2014/10/proses-

pengambilan-keputusan.html

Teori Penguatan. (2014). Retrieved from http://perilakuorganisasi.com/teori-penguatan.html 


\section{BUKU AJAR PERILAKU ORGANISASI}

